\title{
Postprandial muscle protein synthesis in the elderly
}

Citation for published version (APA):

Pennings, B. P. A. (2013). Postprandial muscle protein synthesis in the elderly. [Doctoral Thesis, Maastricht University]. Datawyse / Universitaire Pers Maastricht. https://doi.org/10.26481/dis.20130403bp

Document status and date:

Published: 01/01/2013

DOI:

10.26481/dis.20130403bp

Document Version:

Publisher's PDF, also known as Version of record

\section{Please check the document version of this publication:}

- A submitted manuscript is the version of the article upon submission and before peer-review. There can be important differences between the submitted version and the official published version of record.

People interested in the research are advised to contact the author for the final version of the publication, or visit the DOI to the publisher's website.

- The final author version and the galley proof are versions of the publication after peer review.

- The final published version features the final layout of the paper including the volume, issue and page numbers.

Link to publication

\footnotetext{
General rights rights.

- You may freely distribute the URL identifying the publication in the public portal. please follow below link for the End User Agreement:

www.umlib.nl/taverne-license

Take down policy

If you believe that this document breaches copyright please contact us at:

repository@maastrichtuniversity.nl

providing details and we will investigate your claim.
}

Copyright and moral rights for the publications made accessible in the public portal are retained by the authors and/or other copyright owners and it is a condition of accessing publications that users recognise and abide by the legal requirements associated with these

- Users may download and print one copy of any publication from the public portal for the purpose of private study or research.

- You may not further distribute the material or use it for any profit-making activity or commercial gain

If the publication is distributed under the terms of Article $25 \mathrm{fa}$ of the Dutch Copyright Act, indicated by the "Taverne" license above, 


\section{Postprandial muscle protein synthesis in the elderly}




\section{iffín}
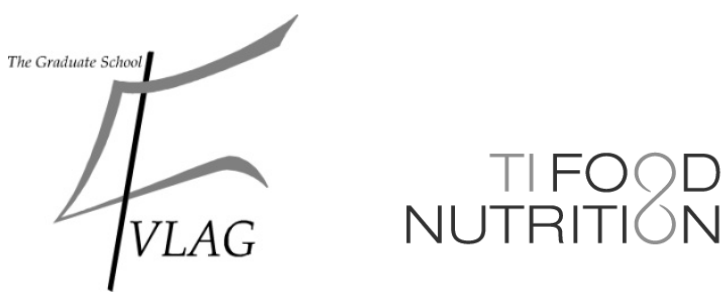

The studies presented in this thesis were performed within NUTRIM School for Nutrition, Toxicology and Metabolism which participates in the Graduate School VLAG (Food Technology, Agrobiotechnology, Nutrition and Health Sciences), accredited by the Royal Netherlands Academy of Arts and Sciences, and within the framework of TI Food and Nutrition, a public-private partnership of science, industry and government conducting strategic research in food and nutrition.

(C) 2013 Bart Pennings, Maastricht

Layout: Bart Pennings

Cover design: Wendy Tönjes en Suzanne Kölker

Production: Datawyse, Universitaire Pers Maastricht

ISBN 9789461592163 


\title{
Postprandial muscle protein synthesis in the elderly
}

\author{
PROEFSCHRIFT \\ ter verkrijging van de graad van doctor \\ aan de Universiteit Maastricht, \\ op gezag van Rector Magnificus, Prof. dr. L.L.G. Soete \\ volgens het besluit van het College van Decanen, \\ in het openbaar te verdedigen \\ op woensdag 3 april 2013 om 14:00 uur \\ door \\ Bartholomeus Petrus Antonius Pennings \\ geboren te Eindhoven op 2 september 1981
}

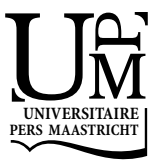


Promotor

Prof. dr. L.J.C van Loon

\section{Beoordelingscommissie}

Prof. dr. A.M.W.J. Schols (voorzitter)

Prof. dr. R.P. Mensink

Dr. S.W.M. Olde-Damink

Prof. dr. B.B. Rasmussen (University of Texas Medical Branch, USA)

Prof. dr. G.J. van der Vusse 


\section{Contents}

Chapter 1 General introduction

Chapter 2 Exercising before protein intake allows for a greater use of dietary protein-derived amino acids for de novo muscle protein synthesis in both young and elderly men

Chapter 3 Whey protein stimulates postprandial muscle protein accretion more effectively than do casein and casein hydrolysate in older men

Chapter 4 Amino acid absorption and subsequent muscle protein accretion following graded intakes of whey protein in elderly men

Chapter 5 The production of intrinsically labeled milk and meat protein is feasible and provides functional tools for human nutrition research

Chapter 6 Minced beef is more rapidly digested and absorbed when 99 compared with beef steak, resulting in greater postprandial protein retention in older men

Chapter 7 General discussion

Summary

Samenvatting

Acknowledgements

Curriculum Vitae

List of publications

Financial support 

Chapter 1

General introduction 


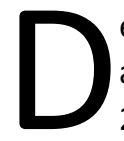
emographics of the world's population show that the number of individuals aged 60 years and over will increase from 600 million in 2000 to more than

2 billion by 2050 (1). Specifically, elderly people aged 80 years and over are presently the fasted growing subpopulation in the developed countries. As a consequence of this global aging, our healthcare system will face serious challenges because of increased morbidity and greater need for hospitalization and institutionalization. Good health is essential for older people to remain independent and to continue with actively taking part in family and community life. One of the factors that plays an important role in the ability to maintain a healthy active lifestyle is the preservation of skeletal muscle mass (2). However, after the fifth decade of life, a progressive loss of skeletal muscle mass is observed with increasing age (3). Therefore, interventional strategies are needed to attenuate the agerelated decline in skeletal muscle mass and, as such, promote healthy aging.

\section{Muscle loss with aging}

Skeletal muscle mass generally contributes up to $50 \%$ of total body weight in young adults but declines with aging to $25 \%$ when reaching an age of $75-80$ years (3). This loss of muscle mass is typically offset by gains in fat mass and is most notable in the lower limb muscles (Figure 1). In addition, the loss of skeletal muscle mass is accompanied by the loss of muscle strength and a decline in physical performance (4$6)$. These progressive muscular changes are termed sarcopenia, with sarcos meaning 'flesh' and penia meaning 'lack of' (7). Primarily, sarcopenia is considered a process with no other cause evident except for the aging process itself (8). With normal human growth and development, skeletal muscle mass increases until the third decade and then remains relatively stable until the age of $40-50$ years. Thereafter, a gradual but progressive loss is generally observed (3).

The consequences of sarcopenia on health status are numerous and include increased risk of falls and fractures, impaired ability to perform activities of daily living, and loss of independence (4-6). Apart from these, more obvious, consequences of reduced muscle strength and physical performance, sarcopenia also induces a greater risk of developing chronic metabolic diseases. Skeletal muscle tissue comprises $\sim 70 \%$ of body cell mass and therefore plays a major role in glucose, fat, and protein metabolism. A decline in muscle mass reduces the capacity for postprandial blood glucose disposal thereby impairing glycemic control. Also, a decline in muscle mass and the subsequent greater relative fat mass increase the likelihood of ectopic lipid deposition in liver and skeletal muscle tissue. The latter will further impair insulin sensitivity and contributes to the development of hyperglycemia, hyperlipidemia, hypertension and, eventually, type 2 diabetes and/or cardiovascular co-morbidities. 

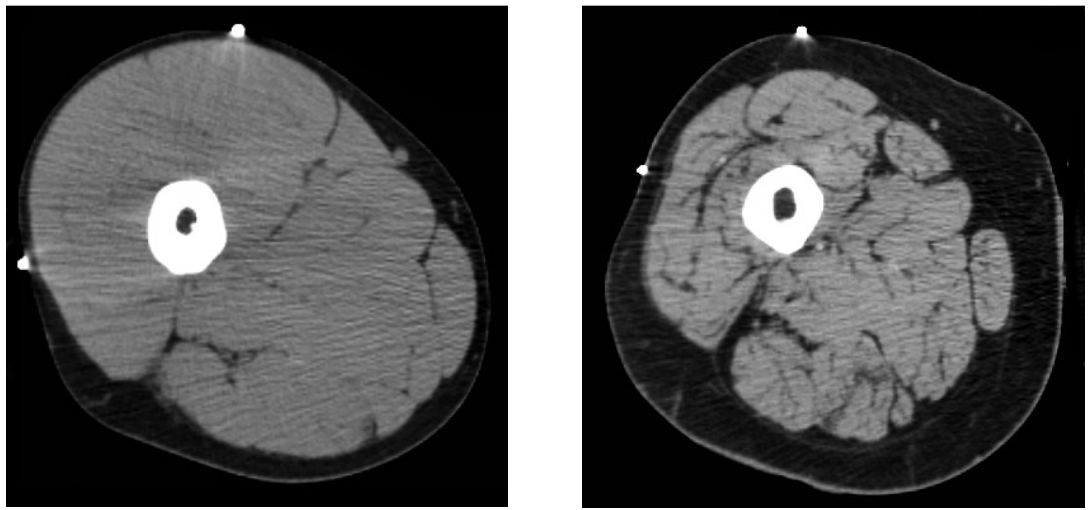

Figure 1. CT-scan of the upper leg (mid-thigh level) in a young (25 years; left panel) and elderly ( 81 years; right panel) male subject, matched for body mass and height. Note the reduced muscle area (in grey) surrounding the bone (in white), increased subcutaneous fat (dark area surrounding the muscles), and increased fat and connective infiltration (dark areas within the muscles) in the upper leg of the elderly subject compared with the young control subject (9).

\section{Muscle protein turnover}

Proteins serve as the main building blocks of our body and consist of amino acids linked together via peptide-bonds. Muscle proteins account for about $40 \%$ of total body proteins and serve as the principal reservoir of amino acids. The body's free amino acid pool is small compared with the body's protein-bound amino acid pool, e.g. $200 \mathrm{~g}$ versus $12 \mathrm{~kg}$ for a 70-kg adult man, and is greatly influenced by daily cycles of feeding and fasting (10). Both amino acid pools are closely related through the process of whole-body protein turnover, which is crucial for maintaining the quality and quantity of body protein. Through the process of whole-body protein turnover, proteins are constantly being broken down and re-synthesized (Figure 2). On a whole-body level this occurs with a rate of approximately 3-4\% per day. However, our body contains numerous different proteins, each with a specific amino acid sequence, structure, function and turnover rate. For example, the turnover rate of intestinal protein is $30-40 \%$ per day, whereas the turnover rate of muscle protein is just $1-2 \%$ per day (10). These turnover rates indicate that our intestinal surface of $100 \mathrm{~m}^{2}$ is renewed every 3 days, whereas it takes 3 months to renew our skeletal muscle tissue. Nevertheless, taking into account its mass, skeletal muscle protein is responsible for up to $50 \%$ of whole-body protein turnover.

In the absence of food intake, i.e. during fasting conditions, muscle protein breakdown exceeds muscle protein synthesis which creates a negative muscle protein balance and, as such, a continuous flow of amino acids into the body's free amino acid pool (11). While the majority of amino acids that are released through muscle protein breakdown are reincorporated into newly synthesized protein, a small proportion is consumed for energy or lost otherwise and must therefore be re- 
placed. Amino acid losses can be replaced by consuming dietary protein (12). Following food intake, i.e. in the postprandial phase, digestion and absorption of dietary protein will result in an increased availability of plasma amino acids (13). A rapid increase in postprandial plasma amino acid concentrations strongly increases muscle protein synthesis rates, while moderately inhibiting muscle protein breakdown rates via a concomitant rise in plasma insulin concentrations (14). These changes will result in a shift from a negative muscle protein balance to a positive muscle protein balance and, as such, will replace the loss of muscle protein that occurred in the post-absorptive phase. Consequently, daily fluctuations in muscle protein balance in the normal fed and fasted state allow for muscle mass preservation.
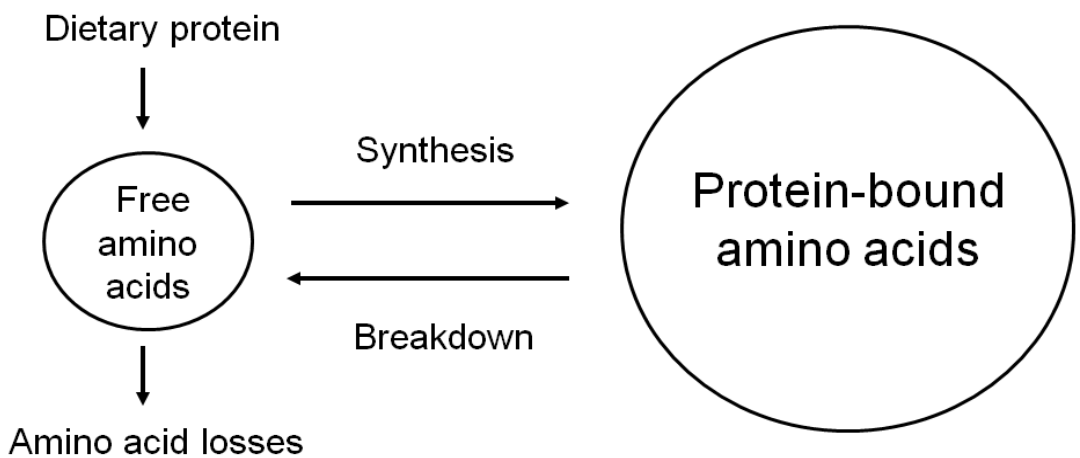

Figure 2. General model of whole-body protein turnover. The consumption of dietary protein is instrumental to replace amino acid losses and maintain protein balance.

\section{Anabolic resistance}

The decline in skeletal muscle mass with aging must be attributed to a disruption in the regulation of skeletal muscle protein turnover, leading to a structural imbalance between muscle protein synthesis and breakdown rates. As basal (fasting) muscle protein synthesis and breakdown rates do not seem to differ substantially between young and older adults (15), many research groups have since refocused on the muscle protein synthetic response to food intake. It has well been established that protein synthesis in skeletal muscle tissue is highly responsive to food intake (12). Recent work suggests that the muscle protein synthetic response to food intake is impaired in older persons (16-18). Such an impaired muscle protein synthetic response would not allow for the complete replacement of muscle proteins lost during the fasted state. On a daily basis, this would result in a net loss of muscle protein. Daily net muscle protein losses could result into severe losses of muscle mass over the course of many years. Although, the reported impairments in muscle protein synthesis in older adults have only been observed under nonphysiological conditions, i.e. following ingestion (16) or infusion (17) of free amino 
acids while plasma insulin levels were kept constant, the proposed anabolic resistance to food intake is now being regarded as a possible key-factor in the etiology of sarcopenia (18).

The mechanisms that might be responsible for the proposed anabolic resistance to food intake in the elderly remain to be elucidated. Impaired digestion and absorption kinetics of dietary protein might attenuate or reduce the appearance rate of amino acids in the circulation, thereby lowering the postprandial muscle protein synthetic rate. Furthermore, amino acid uptake in the splanchnic area has been shown to be elevated in the elderly, which implies that less of the ingested amino acids would be available for muscle protein synthesis $(19,20)$. Postprandial hyperinsulinemia can increase skeletal muscle perfusion and, as such, allow for a greater amino acid delivery to the muscle (21). However, the role of insulin in the regulation of the postprandial muscle protein anabolic response is still controversial. Some propose that insulin is rather permissive instead of modulatory, and that plasma insulin levels of $\sim 10-15 \mu \mathrm{U} \cdot \mathrm{mL}^{-1}$ are already sufficient to allow a maximal muscle protein synthetic response $(22,23)$. In contrast, others suggested that muscle protein synthesis is resistant to the anabolic action of physiological hyperinsulinemia in older adults $(24,25)$. On an extracellular level, the sensing of amino acids and/or insulin might be a limiting factor for senescent muscle tissue. The extracellular increase in essential amino acid (EAA) concentrations, with leucine in particular (26), seems to represent the main anabolic signal responsible for stimulating postprandial muscle protein synthesis rates $(22,27)$. In accordance, the attenuated muscle protein synthetic response to food intake in the elderly can be, at least partly, compensated for by increasing the leucine content of a meal (28, 29). The intracellular mechanisms that regulate (muscle) protein synthesis are in part mediated through downstream signaling of the insulin/insulin-like growth factor I (IGF-I) receptor via the mammalian target of rapamycin (mTOR) pathway (30). Cuthbertson et al. (16) reported that signaling protein concentrations differed between old and young muscle and showed an attenuated rise in the activation of key-signaling proteins of the mTOR pathway after ingesting $10 \mathrm{~g}$ essential amino acids (EAAs) in the elderly versus the young. These findings seem to be in line with observations by Guillet et al. (17) and suggest that an anabolic signal might not be sensed and/or transduced as well in senescent muscle.

The aforementioned mechanisms are all interrelated; yet, the focus of this thesis will be on the role of digestion and absorption kinetics of dietary protein and the subsequent muscle protein synthetic response.

\section{Protein digestion and absorption kinetics}

The postprandial availability of dietary protein-derived amino acids is largely determined by the digestion and absorption kinetics of the specific proteins in a meal (13). Dietary proteins are often classified as either fast or slow digestible proteins 
(31). Interestingly are the observations that ingestion of slow digestible protein leads to a more positive protein balance compared with the ingestion of fast digestible protein in healthy young subjects (32). However, in the elderly, the postprandial protein anabolic response turned out to be the opposite; ingestion of fast digestible protein was shown to result in greater net protein retention compared with slow digestible protein when provided in healthy elderly men (33). The latter might be attributed to the proposed anabolic resistance of the muscle protein synthetic machinery to become activated in elderly muscle. In accordance, it has been reported that protein pulse feeding (providing up to $80 \%$ of daily protein intake in one meal) leads to greater protein retention than ingesting the same amount of protein provided over four meals throughout the day (spread-feeding) in elderly women (34). In agreement, pulse feeding did not lead to greater protein retention than spread feeding when applied in young females (35).

The findings on fast vs slow digestible protein and pulse- vs spread feeding seem to indicate that the threshold of plasma amino acid(s) concentration that needs to be reached to allow an adequate muscle protein synthetic response to food intake is elevated in the elderly. This concept has been illustrated in Figure 3. Whereas young adults might benefit more from a prolonged, but relatively modest increase in plasma amino acid availability, older adults may require higher peak levels of plasma amino acid concentrations to allow for an optimal muscle protein synthetic response to food intake.

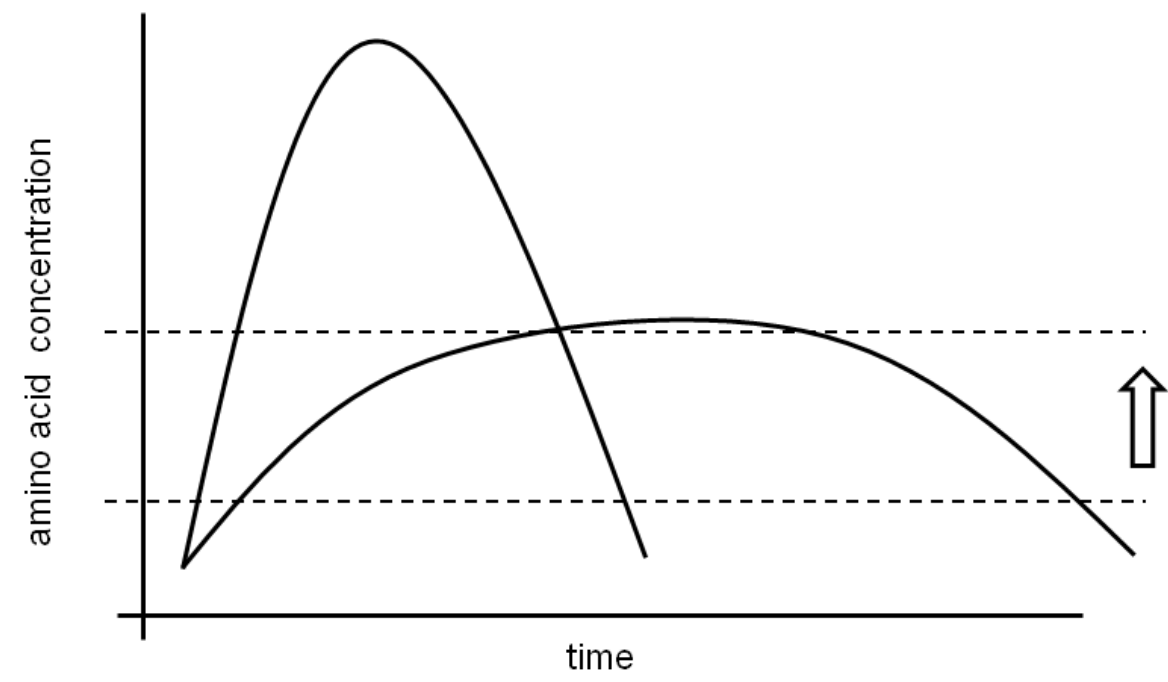

Figure 3. Suggested concept of an elevated anabolic threshold with increasing age. Dotted lines represent the (elevated) anabolic threshold and the curves represent typical amino acid concentrations following ingestion of fast and slow digestible protein. Note how the anabolic response can be impaired with the slow/spread curve compared with the fast/pulse curve when the threshold has been increased. 
Besides choosing specific fast digestible protein sources and/or changing the composition of the macronutrients in the diet, also the structure of a (slow) protein can be modified to resemble a fast digestible protein. By enzymatic hydrolysation of slow digestible intact micellar casein, a casein hydrolysate can be obtained consisting of $>90 \%$ di- and tripeptides, while retaining its original amino acid composition. Koopman et al. (36) performed a study in which elderly men consumed a single bolus of intact casein and casein hydrolysate in a cross-over design. The results showed that the casein hydrolysate resembled a faster digestible protein, which resulted in a greater availability of dietary amino acids in the circulation during the $6 \mathrm{~h}$ postprandial period and tended to further increase muscle protein synthesis rates when compared with the slower digestible intact casein (36).

In summary, modulating protein digestion and absorption kinetics represents a powerful tool to promote postprandial muscle protein synthesis rates in older adults. While some proteins have the right chemical properties, others could be made more anabolic with some structural changes without affecting their unique amino acid composition.

\section{Stable isotope methodology: intrinsically labeled protein}

For many years, stable isotopes have been applied in human research because they are effective, safe, and non-toxic (37). Molecules labeled with a stable isotope can be used to 'trace' the metabolism of this molecule in vivo in the human body. The molecule of interest is then referred to as the 'tracee', whereas the labeled molecule is referred to as the 'tracer' (38). In general, the turnover of a specific amino acid (tracee) is investigated through isotope dilution via continuous intravenous administration of a labeled amino acid (tracer). When studying protein metabolism, the use of labeled EAAs is warranted as by definition EAAs can only appear in the plasma via food intake or protein breakdown. However, when investigating the impact of feeding on protein metabolism, most groups generally apply a research design in which labeled leucine or phenylalanine is co-ingested, with or without continuous infusion of an intravenous amino acid tracer (39). The fact that the oral tracer is being administered as a free amino acid and the bulk of amino acids are provided as intact dietary protein introduces substantial methodological limitations.

Free amino acids and protein-derived amino acids exhibit an entirely different timing and efficiency of intestinal absorption $(13,33,40)$. Therefore, dietary protein with a labeled amino acid incorporated within its protein matrix is warranted to directly assess the appearance rate of dietary protein-derived amino acids from the gut into the circulation. However, such intrinsically labeled dietary protein is not commercially available and only few reports describe the production of stable isotope-labeled proteins for more specific purposes (41-43). Previously, intrinsically labeled milk protein has been produced by intravenous infusion of L-[1- $\left.{ }^{13} \mathrm{C}\right]$ leucine 
in lactating dairy cows, collection of the milk, and purification of the milk protein fractions (Figure 4). This method allows for the production of intrinsically labeled protein to be used on a larger scale in human nutrition research (44). Specifically, the impact of protein digestion and absorption kinetics on whole-body protein metabolism was investigated, which led to the development of the fast-slow protein concept (31). However, the enrichment level of the labeled proteins previously used was not high enough $(\leq 10 \%)$ to measure the subsequent incorporation of labeled amino acids in skeletal muscle tissue following ingestion of meal-like amounts of dietary protein. Therefore, the impact of protein digestion and absorption kinetics on postprandial muscle protein synthesis remains to be established.

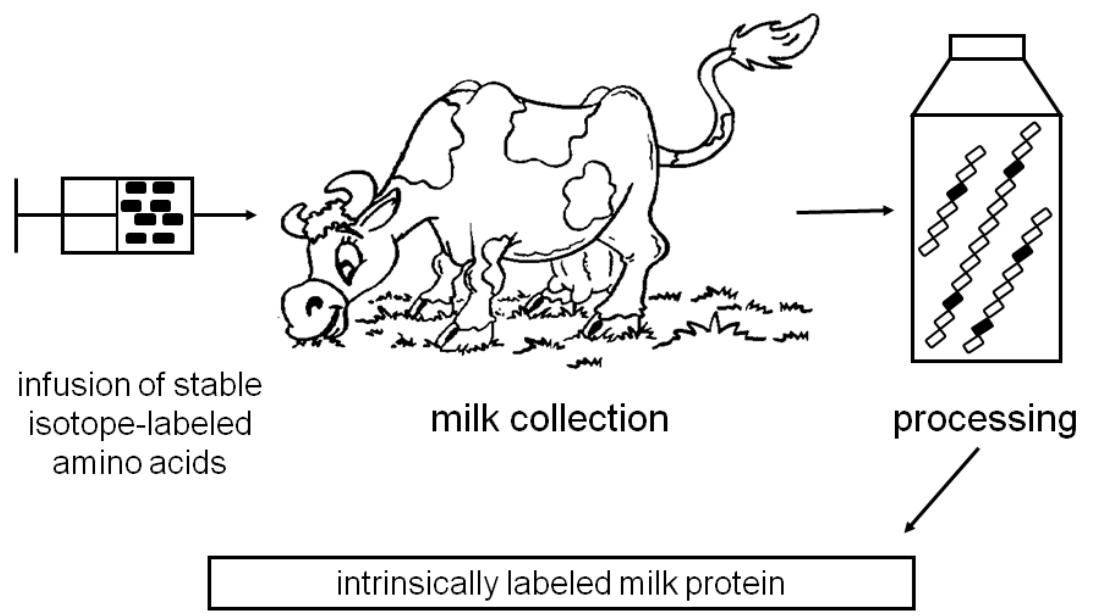

Figure 4. The production of intrinsically labeled milk protein (44).

Our lab extended on the work by Boirie et al. (44) by infusing large quantities of L$\left[1-{ }^{13} \mathrm{C}\right]$ phenylalanine in lactating dairy cows and pooling the milk collected during peak plateau enrichment levels (45). As a result, L- $\left[1-{ }^{13} \mathrm{C}\right]$ phenylalanine enrichments in the collected milk protein as high as $29.4 \%$ were achieved. Such high enrichment levels are necessary when aiming to assess both protein digestion and absorption kinetics as well as subsequent skeletal muscle protein synthesis rates following the ingestion of a meal-like amount of protein. The experimental work presented in this thesis includes the use of these highly enriched, intrinsically labeled proteins to allow for the in vivo assessment of postprandial muscle protein synthesis in young and older adults. 


\section{Thesis outline}

This thesis describes a series of dietary interventions that were aimed to effectively increase the postprandial muscle protein synthetic response to food intake in older adults. In Chapter 2, we first compared dietary protein digestion and absorption kinetics and subsequent postprandial muscle protein synthesis rates following ingestion of a meal-like amount of protein between young and older adults. Because some level of physical activity generally precedes food intake in normal daily life, we assessed the postprandial muscle protein synthetic response both at rest and following physical activity. In Chapter 3, we determined to what extent dietary protein digestion and absorption kinetics as well as amino acid composition modulate postprandial muscle protein synthesis rates in elderly males. Therefore, we compared protein digestion and absorption kinetics and subsequent postprandial muscle protein accretion following the ingestion of whey, casein, and casein hydrolysate. In Chapter 4, we determined the impact of the amount of (whey) protein ingested on protein digestion and absorption kinetics, whole-body protein balance, and subsequent postprandial muscle protein accretion in elderly men. In Chapter 5, we describe the production of intrinsically labeled milk protein with an enrichment level that allows the assessment of both dietary protein digestion and absorption kinetics as well as subsequent de novo muscle protein accretion. Furthermore, we tested the feasibility to produce intrinsically labeled meat protein that would allow the in vivo assessment of protein digestion and absorption kinetics following beef consumption in humans. In Chapter 6, we determined the effect of meat texture on digestion and absorption kinetics and subsequent postprandial protein retention in older adults. Therefore, older men were randomly assigned to a cross-over experiment in which they consumed intrinsically L-[1${ }^{13} \mathrm{C}$ ]phenylalanine-labeled beef, provided as a steak or as minced beef. Finally, Chapter 7 combines the results and conclusions from the previous chapters and places them in a broader perspective. In addition, we present future research aims that extend on the present knowledge and will allow for the development of more effective dietary interventions to attenuate the loss of muscle mass with aging. 


\section{References}

1. WHO. Ageing (online). http://www.who.int/topics/ageing/en 2012.

2. Melton L, 3rd, Khosla S, Crowson CS, O'Connor MK, O'Fallon WM, Riggs BL. Epidemiology of sarcopenia. J Am Geriatr Soc 2000;48:625-30.

3. Short KR, Nair KS. The effect of age on protein metabolism. Curr Opin Clin Nutr Metab Care 2000;3:39-44.

4. Cawthon PM, Marshall LM, Michael Y, et al. Frailty in older men: prevalence, progression, and relationship with mortality. J Am Geriatr Soc 2007;55:1216-23.

5. Lauretani F, Russo CR, Bandinelli S, et al. Age-associated changes in skeletal muscles and their effect on mobility: an operational diagnosis of sarcopenia. J Appl Physiol 2003;95:1851-60.

6. Topinkova E. Aging, disability and frailty. Ann Nutr Metab 2008;52 Suppl 1:6-11.

7. Rosenberg IH. Sarcopenia: origins and clinical relevance. J Nutr 1997;127:990S-991S.

8. Cruz-Jentoft AJ, Baeyens JP, Bauer JM, et al. Sarcopenia: European consensus on definition and diagnosis: Report of the European Working Group on Sarcopenia in Older People. Age Ageing 2010;39:412-23.

9. Koopman R, van Loon LJ. Aging, exercise, and muscle protein metabolism. J Appl Physiol 2009;106:2040-8.

10. Waterlow JC. Protein turnover. CABI, Oxfordshire 2006.

11. Phillips SM, Tipton KD, Aarsland A, Wolf SE, Wolfe RR. Mixed muscle protein synthesis and breakdown after resistance exercise in humans. Am J Physiol 1997;273:E99-107.

12. Rennie MJ, Edwards RH, Halliday D, Matthews DE, Wolman SL, Millward DJ. Muscle protein synthesis measured by stable isotope techniques in man: the effects of feeding and fasting. Clin Sci (Lond) 1982;63:519-23.

13. Boirie $\mathrm{Y}$, Gachon $\mathrm{P}$, Corny $\mathrm{S}$, Fauquant J, Maubois JL, Beaufrere B. Acute postprandial changes in leucine metabolism as assessed with an intrinsically labeled milk protein. Am J Physiol 1996;271:E1083-91.

14. Liu Z, Barrett EJ. Human protein metabolism: its measurement and regulation. Am J Physiol Endocrinol Metab 2002;283:E1105-12.

15. Volpi E, Sheffield-Moore M, Rasmussen BB, Wolfe RR. Basal muscle amino acid kinetics and protein synthesis in healthy young and older men. JAMA 2001;286: 1206-12.

16. Cuthbertson $D$, Smith $K$, Babraj J, et al. Anabolic signaling deficits underlie amino acid resistance of wasting, aging muscle. FASEB J 2005;19:422-4.

17. Guillet $C$, Prod'homme $M$, Balage $M$, et al. Impaired anabolic response of muscle protein synthesis is associated with S6K1 dysregulation in elderly humans. FASEB J 2004;18:1586-7.

18. Burd NA, Wall BT, van Loon $\amalg$. The curious case of anabolic resistance: old wives' tales or new fables? J Appl Physiol 2012;112:1233-5.

19. Boirie $Y$, Gachon $P$, Beaufrere B. Splanchnic and whole-body leucine kinetics in young and elderly men. Am J Clin Nutr 1997;65:489-95.

20. Volpi E, Mittendorfer B, Wolf SE, Wolfe RR. Oral amino acids stimulate muscle protein anabolism in the elderly despite higher first-pass splanchnic extraction. Am J Physiol 1999;277:E513-20.

21. Clark MG, Rattigan S, Barrett EJ. Nutritive blood flow as an essential element supporting muscle anabolism. Curr Opin Clin Nutr Metab Care 2006;9:185-9.

22. Bohe J, Low A, Wolfe RR, Rennie MJ. Human muscle protein synthesis is modulated by extracellular, not intramuscular amino acid availability: a dose-response study. J Physiol 2003;552:315-24.

23. Greenhaff PL, Karagounis LG, Peirce N, et al. Disassociation between the effects of amino acids and insulin on signaling, ubiquitin ligases, and protein turnover in human muscle. Am J Physiol Endocrinol Metab 2008;295:E595-604.

24. Volpi E, Mittendorfer B, Rasmussen BB, Wolfe RR. The response of muscle protein anabolism to combined hyperaminoacidemia and glucose-induced hyperinsulinemia is impaired in the elderly. J Clin Endocrinol Metab 2000;85:4481-90. 
25. Fujita S, Glynn EL, Timmerman KL, Rasmussen BB, Volpi E. Supraphysiological hyperinsulinaemia is necessary to stimulate skeletal muscle protein anabolism in older adults: evidence of a true agerelated insulin resistance of muscle protein metabolism. Diabetologia 2009;52:1889-98.

26. Smith K, Barua JM, Watt PW, Scrimgeour CM, Rennie MJ. Flooding with L- $\left[1-{ }^{13}\right.$ C]leucine stimulates human muscle protein incorporation of continuously infused L- $\left[1-{ }^{13} \mathrm{C}\right]$ valine. Am J Physiol 1992;262:E372-6.

27. Volpi E, Kobayashi H, Sheffield-Moore M, Mittendorfer B, Wolfe RR. Essential amino acids are primarily responsible for the amino acid stimulation of muscle protein anabolism in healthy elderly adults. Am J Clin Nutr 2003;78:250-8.

28. Katsanos CS, Kobayashi H, Sheffield-Moore M, Aarsland A, Wolfe RR. A high proportion of leucine is required for optimal stimulation of the rate of muscle protein synthesis by essential amino acids in the elderly. Am J Physiol Endocrinol Metab 2006;291:E381-7.

29. Rieu I, Balage M, Sornet $C$, et al. Leucine supplementation improves muscle protein synthesis in elderly men independently of hyperaminoacidaemia. J Physiol 2006;575:305-15.

30. Kimball SR, Jefferson LS. Molecular mechanisms through which amino acids mediate signaling through the mammalian target of rapamycin. Curr Opin Clin Nutr Metab Care 2004;7:39-44.

31. Boirie $Y$, Dangin M, Gachon P, Vasson MP, Maubois JL, Beaufrere B. Slow and fast dietary proteins differently modulate postprandial protein accretion. Proc Natl Acad Sci U S A 1997;94:14930-5.

32. Dangin M, Boirie $Y$, Garcia-Rodenas $C$, et al. The digestion rate of protein is an independent regulating factor of postprandial protein retention. Am J Physiol Endocrinol Metab 2001;280:E340-8.

33. Dangin $M$, Boirie $Y$, Guillet $C$, Beaufrere B. Influence of the protein digestion rate on protein turnover in young and elderly subjects. J Nutr 2002;132:3228S-33S.

34. Arnal MA, Mosoni L, Boirie $Y$, et al. Protein pulse feeding improves protein retention in elderly women. Am J Clin Nutr 1999;69:1202-8.

35. Arnal MA, Mosoni L, Boirie $Y$, et al. Protein feeding pattern does not affect protein retention in young women. J Nutr 2000;130:1700-4.

36. Koopman R, Crombach N, Gijsen AP, et al. Ingestion of a protein hydrolysate is accompanied by an accelerated in vivo digestion and absorption rate when compared with its intact protein. Am J Clin Nutr 2009;90:106-15.

37. Rennie MJ. An introduction to the use of tracers in nutrition and metabolism. Proc Nutr Soc 1999;58:935-44.

38. Wolfe RR, Chinkes DL. Isotope tracers in metabolic research. Wiley-Liss, New York. 2005.

39. Wagenmakers AJ. Tracers to investigate protein and amino acid metabolism in human subjects. Proc Nutr Soc 1999;58:987-1000.

40. Metges $C C$, El-Khoury $A E$, Selvaraj $A B$, et al. Kinetics of $L-\left[1-{ }^{13} C\right]$ leucine when ingested with free amino acids, unlabeled or intrinsically labeled casein. Am J Physiol Endocrinol Metab 2000;278:E1000-9.

41. Evenepoel P, Hiele M, Luypaerts A, et al. Production of egg proteins, enriched with L- $\left[1-{ }^{13} \mathrm{C}\right]$ leucine, for the study of protein assimilation in humans using the breath test technique. J Nutr 1997;127:327-31.

42. Berthold HK, Hachey DL, Reeds PJ, Thomas OP, Hoeksema S, Klein PD. Uniformly ${ }^{13}$ C-labeled algal protein used to determine amino acid essentiality in vivo. Proc Natl Acad Sci U S A 1991;88:8091-5.

43. Grusak MA, Pezesghi S. Uniformly ${ }^{15} \mathrm{~N}$-labeled soybean seeds produced for use in human and animal nutrition studies: description of a recirculating hydrophonic system and whole plant nutrient and environmental requirements. J Sci Food Agric 1994;64:223-230.

44. Boirie Y, Fauquant J, Rulquin H, Maubois JL, Beaufrere B. Production of large amounts of L-[1$\left.{ }^{13} \mathrm{C}\right]$ leucine-enriched milk proteins by lactating cows. J Nutr 1995;125:92-8.

45. Van Loon LJ, Boirie $\mathrm{Y}, \mathrm{Gijsen} \mathrm{AP}$, et al. The production of intrinsically labeled milk protein provides a functional tool for human nutrition research. J Dairy Sci 2009;92:4812-22. 



\section{Chapter 2}

\section{Exercising before protein intake allows for a greater use of dietary protein-derived amino acids for de novo muscle protein synthesis in both young and elderly men}

American Journal of Clinical Nutrition $2011 \mathrm{Feb}$;93(2):322-31 


\begin{abstract}
The aim of this study was to compare in vivo dietary protein digestion and absorption kinetics and subsequent postprandial muscle protein synthesis rates at rest and following exercise between young and elderly men. Twenty-four young $(21 \pm 1$ y) and 24 elderly (74 \pm 1 y) men consumed a $20 \mathrm{~g}$ bolus of intrinsically L-[1${ }^{13} \mathrm{C}$ ]phenylalanine-labeled protein at rest (REST) or following exercise (EXC). Continuous infusions with L-[ring- ${ }^{2} \mathrm{H}_{5}$ ]phenylalanine were applied, with blood and muscle samples collected, to assess in vivo protein digestion and absorption kinetics and subsequent postprandial muscle protein synthesis rates. Exogenous phenylalanine appearance rates expressed over time did not differ between groups. No differences were observed in plasma phenylalanine availability between the young and elderly ( $51 \pm 2$ vs $51 \pm 1 \%$ ) or between REST and EXC ( $52 \pm 1$ vs $49 \pm 1 \%)$. Muscle protein synthesis rates calculated from the oral tracer were $0.0620 \pm 0.0065$ and $0.0560 \pm 0.0039 \% \cdot h^{-1}$ at REST and $0.0719 \pm 0.0057$ and $0.0727 \pm 0.0040 \% \cdot h^{-1}$ following EXC in young and elderly men, respectively (age effect, $P=0.62$; exercise effect, $\mathrm{P}<0.05$; interaction of age and exercise, $\mathrm{P}=0.52$ ).

In conclusion, dietary protein digestion and absorption kinetics are not impaired following exercise or at older age. Exercising before protein intake allows for a greater use of dietary protein-derived amino acids for de novo muscle protein synthesis in both young and elderly men.
\end{abstract}




\section{Introduction}

Aging is accompanied by a progressive decline in skeletal muscle mass, termed sarcopenia (1). This age-related loss of skeletal muscle mass is attributed to an imbalance between mixed muscle protein synthesis and breakdown rates. Whereas some have reported significant differences in basal muscle protein synthesis rates between the young and elderly $(2,3)$, others have failed to observe such differences $(4,5)$. Recently, various research groups have started to focus on potential impairments in the muscle protein synthetic response to the main anabolic stimuli, i.e. food intake and exercise. Skeletal muscle protein synthesis is highly responsive to both food intake (5-7) and exercise (8-11) in healthy, young adults. Recent data indicate that the muscle protein synthetic response to food intake $(5,12)$ and exercise (11) may be blunted in the elderly. This proposed anabolic resistance is now being regarded as a possible key-factor in the etiology of sarcopenia. As some level of physical activity generally precedes food intake in normal daily life, it seems evident that the concept of anabolic resistance should be studied in a postprandial state both at rest as well as in post-exercise conditions.

There is much speculation on the mechanisms responsible for the proposed blunted muscle protein synthetic response to food intake in the elderly (13). One of the mechanisms that has been suggested includes an impairment in dietary protein digestion and absorption kinetics (14). Impaired protein digestion and absorption kinetics might reduce the appearance rate of dietary protein-derived amino acids in the circulation, thereby lowering postprandial muscle protein synthesis rates. Evidence to support the existence of in vivo differences in protein digestion and absorption kinetics and subsequent muscle protein synthesis between young and elderly humans has not been provided due to methodological limitations (15). To allow the in vivo assessment of dietary protein digestion and absorption kinetics and postprandial muscle protein synthesis we specifically produced intrinsically L$\left[1-{ }^{13} \mathrm{C}\right]$ phenylalanine labeled protein by collecting milk protein from lactating cows that were infused with large amounts of $\mathrm{L}-\left[1-{ }^{13} \mathrm{C}\right]$ phenylalanine (16). Recently, we showed that dietary protein digestion and absorption kinetics following the ingestion of a large bolus of intrinsically labeled protein (35 g) were not substantially impaired in healthy, elderly men (17). In accordance, anabolic resistance has only been observed in studies applying smaller, meal-like amounts of amino acids $(5,7)$. In the present study, young and elderly subjects were studied following the ingestion of $20 \mathrm{~g}$ intrinsically L-[1- $\left.{ }^{13} \mathrm{C}\right]$ phenylalanine-labeled casein protein at rest or following a single bout of exercise. An equivalent of $20 \mathrm{~g}$ protein (or $10 \mathrm{~g}$ EAA) has been shown to maximize the muscle protein anabolic response in the young $(5,18)$, whereas suboptimal muscle protein synthesis rates have been reported in the elderly (5). In addition, 20 g dietary protein represents a normal, meal-like amount of protein consumed by healthy elderly men in the Netherlands (19). Ingestion of 
the bolus intrinsically labeled casein was combined with continuous intravenous L[ring- ${ }^{2} \mathrm{H}_{5}$ ]-phenylalanine infusion to allow simultaneous assessment of both exogenous and endogenous phenylalanine appearance and disappearance rates and fractional mixed muscle protein synthetic rates (FSR) in vivo in humans.

\section{Methods}

\section{Subjects}

Twenty-four elderly men ( $74 \pm 1 \mathrm{y}$ ) and 24 body-weight matched, young controls (21 \pm 1 y) participated in the present study. Within each age-group subjects were randomly assigned to either the rest (REST) or exercise (EXC) experiment. Subjects' characteristics are presented in Table 1 . None of the subjects had a history of participating in any regular exercise program. All subjects were informed on the nature and possible risks of the experimental procedures before their written informed consent was obtained. This study was approved by the Medical Ethics Committee of the Academic Hospital Maastricht.

\section{Pretesting}

Before selection in the study, all subjects participated in 2 pretesting sessions. These sessions were performed to exclude subjects with type 2 diabetes and/or increased risk of heart failure and to determine the subject's maximal strength (one-repetition maximum, 1RM). In the first session, an oral glucose tolerance test (OGTT) was performed to assess glucose tolerance and screen for type 2 diabetes prevalence according to World Health Organization criteria (20). Body weight and height were assessed prior to the OGTT. Body composition was determined by a dual-energy X-ray absorptiometry scan (DXA, Discovery A, Hologic Corporate, Bedford, MA, USA) and leg volume was measured as described previously (19). After the OGTT, an electrocardiogram (both at rest and during exercise) was performed to screen for heart failure. All eligible subjects were then familiarized with the physical activity protocol and the equipment. Proper lifting technique was demonstrated and practiced for each of the 2 lower-limb exercises (leg press and leg extension). In addition, 1RM was estimated using the multiple repetitions testing procedure (21). During the second screening session, the subjects' true 1RM was determined. After warming-up, the load was set at $90-95 \%$ of the estimated $1 \mathrm{RM}$ and increased after each successful lift. A 5-min resting period between subsequent attempts was allowed. A repetition was valid if the subject was able to complete the entire lift in a controlled manner without assistance. There was at least a 7-day interval between the 2 sessions and the experiment. 


\section{Diet and activity before testing}

All subjects consumed a standardized meal $\left(33 \pm 2 \mathrm{~kJ} \cdot \mathrm{kg}^{-1}\right.$ body weight, consisting of 55 energy\% (E\%) carbohydrate, $15 \mathrm{E} \%$ protein and $30 \mathrm{E} \%$ fat) the evening prior to the experiment. All volunteers were instructed to refrain from any sort of exhaustive physical activity and to keep their diet as constant as possible for 3 days prior to the experiment.

\section{Protocol}

At 8.00 am, after an overnight fast, subjects arrived at the laboratory by car or public transportation. A Teflon catheter was inserted into an antecubital vein for stable isotope infusion. A second Teflon catheter was inserted in a heated dorsal hand vein of the contralateral arm and placed in a hot-box $\left(60^{\circ} \mathrm{C}\right)$ for arterialized blood sampling (22). Following basal blood sample collection ( $t=-120 \mathrm{~min}$ ), the plasma phenylalanine pool was primed with a single intravenous dose of the amino acid tracer L-[ring- ${ }_{-}^{2} \mathrm{H}_{5}$ ]phenylalanine $\left(2 \mu \mathrm{mol} \cdot \mathrm{kg}^{-1}\right)$, after which continuous tracer infusion was started with an infusion rate of $0.044 \pm 0.001 \mu \mathrm{mol} \cdot \mathrm{kg}^{-1} \cdot \mathrm{min}^{-1}$. Thereafter, subjects rested in a supine position for $90 \mathrm{~min}$, after which they either remained in that position for another $30 \mathrm{~min}$ (REST) or performed a $30 \mathrm{~min}$ standardized exercise protocol (EXC).

Immediately thereafter, an arterialized blood sample was drawn and a muscle tissue sample was collected from the vastus lateralis muscle ( $t=0 \mathrm{~min}$ ). Subjects then received a single bolus $(250 \mathrm{~mL})$ of test drink containing $20 \mathrm{~g}$ intrinsically L-[1${ }^{13} \mathrm{C}$ ]phenylalanine-labeled casein protein. Arterialized blood samples were collected at $\mathrm{t}=15,30,45,60,75,90,105,120,150,180,210,240,270,300,330$ and $360 \mathrm{~min}$ with a second muscle biopsy collected at $\mathrm{t}=360 \mathrm{~min}$ from the vastus lateralis in the contralateral limb. Blood samples were collected in EDTA containing tubes and centrifuged at $1000 \mathrm{~g}$ for $5 \mathrm{~min}$ at $4^{\circ} \mathrm{C}$. Aliquots of plasma were frozen in liquid nitrogen and stored at $-80^{\circ} \mathrm{C}$. Muscle biopsies were obtained from the middle region of the vastus lateralis, $15 \mathrm{~cm}$ above the patella and approximately $3 \mathrm{~cm}$ below entry through the fascia, using the percutaneous needle biopsy technique (23). Muscle samples were dissected carefully and freed from any visible nonmuscle material. The muscle samples were immediately frozen in liquid nitrogen and stored at $-80^{\circ} \mathrm{C}$ until further analysis. 
Table 1. Subjects' characteristics.

\begin{tabular}{|c|c|c|c|c|c|c|c|}
\hline & $\begin{array}{l}\text { Young } \\
\text { REST } \\
(n=12)\end{array}$ & $\begin{array}{c}\text { Young } \\
\text { EXC } \\
(n=12)\end{array}$ & $\begin{array}{c}\text { Elderly } \\
\text { REST } \\
(n=12)\end{array}$ & $\begin{array}{c}\text { Elderly } \\
\text { EXC } \\
(n=12)\end{array}$ & $\begin{array}{c}\text { P-value } \\
\text { age }\end{array}$ & $\begin{array}{l}\text { P-value } \\
\text { exercise }\end{array}$ & $\begin{array}{l}\text { P-value } \\
\text { age } x \\
\text { exercise }\end{array}$ \\
\hline Age (yrs) & $21 \pm 1$ & $21 \pm 1$ & $75 \pm 1$ & $73 \pm 1$ & $<0.001$ & 0.22 & 0.29 \\
\hline Weight (kg) & $76.2 \pm 3.6$ & $77.0 \pm 2.1$ & $74.4 \pm 2.3$ & $73.5 \pm 2.1$ & 0.32 & 0.98 & 0.75 \\
\hline BMI $\left(\mathrm{kg} \cdot \mathrm{m}^{-2}\right)$ & $23.4 \pm 1.0$ & $22.8 \pm 0.5$ & $24.9 \pm 0.8$ & $23.6 \pm 0.6$ & 0.13 & 0.23 & 0.65 \\
\hline Fat $\%$ & $15.2 \pm 0.9$ & $15.9 \pm 0.9$ & $20.1 \pm 1.0$ & $17.3 \pm 1.0$ & $<0.05$ & 0.29 & 0.07 \\
\hline Lean body mass (kg) & $64.5 \pm 2.8$ & $64.7 \pm 1.6$ & $59.4 \pm 1.7$ & $60.6 \pm 1.4$ & $<0.05$ & 0.71 & 0.79 \\
\hline Leg volume (L) & $8.7 \pm 0.5$ & $9.1 \pm 0.3$ & $7.4 \pm 0.3$ & $7.5 \pm 0.3$ & $<0.001$ & 0.51 & 0.70 \\
\hline HbA1c (\%) & $5.4 \pm 0.1$ & $5.3 \pm 0.1$ & $6.1 \pm 0.1$ & $6.0 \pm 0.1$ & $<0.001$ & 0.17 & 0.89 \\
\hline Basal glucose $\left(\mathrm{mmol} \cdot \mathrm{L}^{-1}\right)$ & $5.1 \pm 0.1$ & $5.2 \pm 0.1$ & $5.9 \pm 0.2$ & $5.5 \pm 0.1$ & $<0.001$ & 0.25 & 0.13 \\
\hline Basal insulin $\left(\mathrm{mU} \cdot \mathrm{L}^{-1}\right)$ & $10.4 \pm 0.7$ & $9.7 \pm 1.0$ & $9.6 \pm 1.0$ & $10.8 \pm 1.9$ & 0.89 & 0.85 & 0.46 \\
\hline HOMA-IR & $2.4 \pm 0.2$ & $2.2 \pm 0.2$ & $2.5 \pm 0.3$ & $2.7 \pm 0.5$ & 0.35 & 0.97 & 0.64 \\
\hline 1RM leg press (kg) & $254 \pm 17$ & $243 \pm 8$ & $168 \pm 9$ & $176 \pm 8$ & $<0.001$ & 0.91 & 0.39 \\
\hline 1RM leg extension $(\mathrm{kg})$ & $122 \pm 6$ & $121 \pm 5$ & $74 \pm 3$ & $77 \pm 2$ & $<0.001$ & 0.85 & 0.77 \\
\hline
\end{tabular}

Values are expressed as means \pm SEM. Data were analyzed with ANOVA (age x exercise).

\section{Exercise regimen}

The exercise protocol consisted of 30 min moderate intensity exercise, combining both low-intensity cycling and resistance-type exercise tasks. After 5 min of selfpaced cycling at $1.4 \pm 0.1 \mathrm{~W} \cdot \mathrm{kg}^{-1}$ body weight with a cadence of $70-90 \mathrm{rpm}$, subjects performed 6 sets of 10 repetitions on the horizontal leg press machine (Technogym BV, Rotterdam, Netherlands) and 6 sets of 10 repetitions on the leg extension machine (Technogym BV). The first 2 sets of both exercises were performed at $40 \%$ of the subjects' 1 RM. Sets $3-4$, and $5-6$ were performed at $55 \%$ and $75 \%$ of 1 RM, respectively, with 2 min rest intervals between sets. The young and elderly men performed exercise at the same relative intensity.

\section{Preparation of intrinsically labeled protein and beverage composition}

Intrinsically L-[1- $\left.{ }^{13} \mathrm{C}\right]$ phenylalanine-labeled casein protein was obtained by infusing a Holstein cow with large quantities of $\mathrm{L}-\left[1-{ }^{13} \mathrm{C}\right]$ phenylalanine, collecting milk, and purifying the casein fraction as described previously (16). The L-[1${ }^{13} \mathrm{C}$ ]phenylalanine enrichment in the casein fraction averaged 29.2 mole percent excess (MPE). The casein protein met all chemical and bacteriological specifications for human consumption. Subjects received a beverage volume of $250 \mathrm{~mL}$ providing a dose of $20 \mathrm{~g}$ micellar casein protein. Drinks were flavored by adding $5 \mathrm{~mL}$ vanilla flavor (Givaudan, Naarden, The Netherlands) per liter beverage. 


\section{Plasma analyses}

Plasma glucose (Uni Kit III, 07367204, Roche, Basel, Switzerland) concentrations were analyzed with the COBAS-FARA semi-automatic analyzer (Roche). Insulin was analyzed by radio-immunoassay (Insulin RIA kit, LINCO Research Inc., St. Charles, MO, USA). Plasma (100 $\mu \mathrm{L})$ for amino acid analyses was deproteinized on ice with $10 \mathrm{mg}$ dry 5-sulphosalicylic acid, mixed and the clear supernatant was collected after centrifugation. Plasma amino acid concentrations were determined by HPLC, after precolumn derivatization with o-phthaldialdehyde (24). For plasma phenylalanine enrichment measurements, plasma phenylalanine was derivatized to its $t$ butyldimethylsilyl (TBDMS) derivative and its ${ }^{13} \mathrm{C}$ and ${ }^{2} \mathrm{H}$ enrichments were determined by electron ionization gas chromatography-mass spectrometry (GC-MS, Agilent 6890N GC/5973N MSD Little Falls, DE, USA) using selected ion monitoring of masses 336, 337 and 341 for unlabeled and labeled $\left(1-{ }^{13} \mathrm{C}\right.$ and $\left.\mathrm{ring}-{ }^{2} \mathrm{H}_{5}\right)$ phenylalanine, respectively (25). We applied standard regression curves in all isotopic enrichment analysis to assess linearity of the mass spectrometer and to control for the loss of tracer. Enrichments (MPE) were calculated according to Biolo et al. (26) to correct for the presence of both the ${ }^{13} \mathrm{C}$ and ${ }^{2} \mathrm{H}_{5}$ phenylalanine isotopes.

\section{Muscle analyses}

For measurement of $\mathrm{L}-\left[1-{ }^{13} \mathrm{C}\right]$ phenylalanine and L-[ring- $\left.{ }^{2} \mathrm{H}_{5}\right]$ phenylalanine enrichment in the free amino acid pool and mixed muscle protein, $55 \mathrm{mg}$ of wet muscle was freeze-dried. Collagen, blood, and other non-muscle fiber material were removed from the muscle fibers under a light microscope. The isolated muscle fiber mass (10-15 mg) was weighed and 8 volumes ( $8 \mathrm{x}$ dry weight of isolated muscle fibers $x$ wet/dry ratio) of ice-cold $2 \%$ perchloric acid (PCA) were added. The tissue was then homogenized and centrifuged. The supernatant was collected and processed in the same manner as the plasma samples, such that tissue-free L-[1${ }^{13} \mathrm{C}$ ]phenylalanine and L-[ring- ${ }^{2} \mathrm{H}_{5}$ ]-phenylalanine enrichments could be measured using their TBDMS derivatives on a GC-MS.

The protein pellet was washed with 3 additional $1.5 \mathrm{~mL}$ washes of $2 \%$ PCA, dried and hydrolyzed in $6 \mathrm{M} \mathrm{HCl}$ at $120^{\circ} \mathrm{C}$ for $15-18 \mathrm{~h}$. The hydrolyzed protein fraction was dried under a nitrogen stream while heated to $120^{\circ} \mathrm{C}$, then $50 \%$ acetic acid solution was added, and the hydrolyzed protein was passed over a Dowex exchange resin (AG 50W-X8, 100-200 mesh hydrogen form, Biorad, Hercules, CA, USA) using 2M $\mathrm{NH}_{4} \mathrm{OH}$. The eluate was divided over 2 vials for separate measurement of L-[1${ }^{13} \mathrm{C}$ ]phenylalanine and $\mathrm{L}-\left[\right.$ ring- ${ }^{2} \mathrm{H}_{5}$ ]phenylalanine enrichment in mixed muscle protein. The latter was determined by derivatizing $L$-[ring- $\left.{ }^{2} \mathrm{H}_{5}\right]$ phenylalanine to its MTBSTFA-phenylethylamine (27). Thereafter, the ratios labeled/unlabeled derivatives were determined by GC-MS. The L- $\left[1-{ }^{13} \mathrm{C}\right]$ phenylalanine enrichment was determined by derivatization to its $\mathrm{N}(\mathrm{O}, \mathrm{S})$-ethoxycarbonyl ethyl ester. The derivative was measured by GC-C-IRMS (Finnigan MAT 252, Bremen, FRG), using HP Ultra 
I GC-column (\#19091A-112, Hewlett-Packard, Palo. Alto, CA), combustion interface II, and monitoring of ion masses 44 and 45 . By establishing the relationship between the enrichment of a series of $\mathrm{L}-\left[1-{ }^{13} \mathrm{C}\right]$ phenylalanine standards of variable enrichment and the enrichment of the $\mathrm{N}(\mathrm{O}, \mathrm{S})$-ethoxycarbonyl ethyl esters of these standards, the muscle protein-bound enrichment of phenylalanine was determined. Standard regression curves were applied to assess linearity of the mass spectrometer and to control for loss of tracer. The coefficient of variance (CV) for the measurement of $\mathrm{L}-\left[1-{ }^{13} \mathrm{C}\right]$ phenylalanine and L-[ring- $\left.{ }^{2} \mathrm{H}_{5}\right]$ phenylalanine enrichment in mixed muscle protein averaged $1.1 \pm 0.1 \%$ and $1.0 \pm 0.1 \%$, respectively.

\section{Calculations}

Ingestion of L-[1- $\left.{ }^{13} \mathrm{C}\right]$ phenylalanine labeled protein, intravenous infusion of L-[ring${ }^{2} \mathrm{H}_{5}$ ] phenylalanine, and arterialized blood sampling were used to assess whole-body amino acid kinetics in non-steady state conditions. Total, exogenous, and endogenous rate of appearance $\left(R_{a}\right)$ and plasma availability of dietary phenylalanine (i.e., fraction of dietary phenylalanine that appeared in the systemic circulation, Phe $\left.e_{\text {plasma }}\right)$ were calculated using modified Steele's equations $(15,28)$. These parameters were calculated as follows.

$$
\begin{aligned}
& \text { Total } R_{a}=\frac{F-p V \cdot C(t) \cdot \mathrm{d} E_{i v} / \mathrm{d} t}{E_{i v}(t)} \\
& \text { Exo } R_{a}=\frac{\text { TotalR }_{\mathrm{a}} \cdot E_{p o}(t)+p V \cdot \mathrm{d} E_{p o} / \mathrm{d} t}{E_{p r o t}} \\
& \text { Endo } R_{a}=\text { Total } \mathrm{R}_{\mathrm{a}}-\text { Exo } \mathrm{R}_{\mathrm{a}}-\mathrm{F} \\
& \text { Phe } e_{\text {plasma }}=\left(\frac{\mathrm{AUC}_{\text {ExoRa }}}{\mathrm{Phe}_{\text {Prot }}}\right) \cdot B W \cdot 100
\end{aligned}
$$

where $F$ is the intravenous tracer infusion rate, $p V(0.125)$ is the distribution volume for phenylalanine (15), $C(t)$ is the mean plasma phenylalanine concentration between 2 time points, $d E_{i v} / d t$ represents the time-dependent variations of plasma phenylalanine enrichment derived from the intravenous tracer, and $E_{i v}(t)$ is the mean plasma phenylalanine enrichment from the intravenous tracer between 2 consecutive time points. Exo $R_{a}$ represents the plasma entry rate of dietary phenylalanine, $E_{p o}(t)$ is the mean plasma phenylalanine enrichment for the oral tracer, $d E_{p o} / d t$ represents the time-dependent variations of plasma phenylalanine enrich- 
ment derived from the oral tracer, and $E_{\text {prot }}$ is the $\mathrm{L}-\left[1-{ }^{13} \mathrm{C}\right]$ phenylalanine enrichment in the dietary protein. Phe Prot $_{\text {is }}$ is the amount of dietary phenylalanine ingested, $A \cup C_{\text {ExoRa }}$ represents the area under the curve (AUC) of Exo $\mathrm{R}_{\mathrm{a}}$, which corresponds to the amount of dietary phenylalanine that appeared in the circulation over the $6 \mathrm{~h}$ period following drink intake. BW represents the subjects' body weight in $\mathrm{kg}$.

Total rate of disappearance (Total $R_{d}$ ) of phenylalanine equals the rate of phenylalanine hydroxylation (first step in phenylalanine oxidation) and utilization for protein synthesis. This parameter is calculated as follows:

$$
\operatorname{Total} R_{d}=\operatorname{Total} R_{a}-p V \cdot \frac{\mathrm{d} C}{\mathrm{~d} t}
$$

Fractional rate of mixed muscle protein synthesis (FSR) was calculated by dividing the increment in enrichment in the product, i.e. mixed muscle protein-bound L-[1${ }^{13} \mathrm{C}$ ]phenylalanine or $\mathrm{L}-\left[\right.$ ring $-{ }^{2} \mathrm{H}_{5}$ ]phenylalanine, by the enrichment of the precursor. Plasma L- $\left[1-{ }^{13} \mathrm{C}\right]$ phenylalanine and plasma $\mathrm{L}-\left[\right.$ ring- $\left.{ }^{2} \mathrm{H}_{5}\right]$ phenylalanine enrichments were used as precursor pools to provide an estimate for the true fractional synthesis rate of mixed muscle proteins. Plasma L-[ring- $\left.{ }^{2} \mathrm{H}_{5}\right]$ phenylalanine enrichments were significantly correlated with muscle tissue-free enrichments $(r=0.54, \mathrm{P}<0.001)$ and were, as such, corrected to reflect the true precursor pool. Muscle FSR's were calculated as follows (29):

$$
F S R=\frac{\Delta E_{p}}{E_{\text {precursor }} \cdot t} \cdot 100
$$

where $\Delta E_{p}$ is the delta increment of protein bound L- $\left[1-{ }^{13} \mathrm{C}\right]$ phenylalanine or L[ring- ${ }^{2} \mathrm{H}_{5}$ ]phenylalanine, during incorporation periods. $E_{\text {precursor }}$ is the average plasma L- $\left[1-{ }^{13} \mathrm{C}\right]$ phenylalanine or plasma L-[ring- $\left.{ }^{2} \mathrm{H}_{5}\right]$ phenylalanine enrichment during the time period for determination of amino acid incorporation. $t$ indicates the time interval $(h)$ between biopsies.

\section{Statistics}

All data are expressed as means \pm SEM. A two-factor repeated measures mixed model ANOVA with age and exercise as factors was used to compare differences between treatments (REST and EXC) and age-groups (young and elderly) over time. For non-time dependent variables, a two-factor ANOVA with age and exercise as factors was used to compare differences between treatments and age-groups. In case of a significant interaction between age and exercise, a Bonferroni post-hoc test was applied to locate these differences. Statistical significance was set at 
$\mathrm{P}<0.05$. All calculations were performed using SAS (version 6.11; SAS Institute Inc, Cary, NC, USA).

\section{Results}

\section{Plasma analyses}

Plasma insulin concentrations rapidly increased following protein ingestion in all groups (Figure 1). Plasma insulin concentrations averaged 9.8 $\pm 0.5,9.5 \pm 0.7$, $12.6 \pm 1.7$, and $8.7 \pm 1.0 \mathrm{mU} \cdot \mathrm{L}^{-1}$ in the young at rest, young after exercise, elderly at rest, and elderly after exercise, respectively. Plasma insulin concentrations were higher in the elderly at rest compared with the other groups $(P<0.05)$. Plasma glucose concentrations did not change following protein ingestion and averaged $5.2 \pm 0.1,5.0 \pm 0.1,5.4 \pm 0.1$, and $5.3 \pm 0.1 \mathrm{mmol} \cdot \mathrm{L}^{-1}$, respectively.

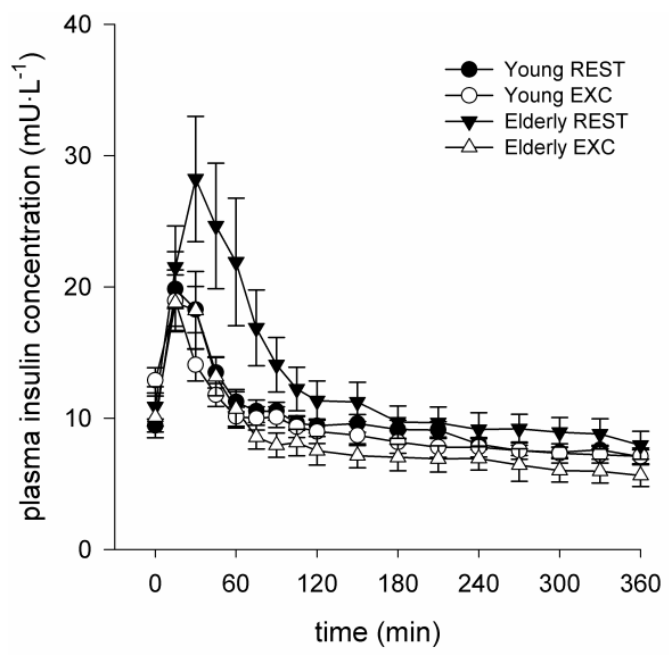

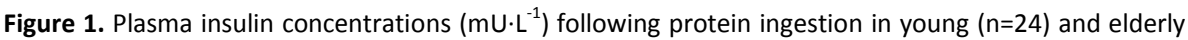
$(n=24)$ men at rest (REST) and following exercise (EXC). Values represent means \pm SEM. Data were analyzed with mixed model repeated measures ANOVA. In case of a significant interaction between age and exercise, a Bonferroni post-hoc test was applied to locate these differences. Time effect, $\mathrm{P}<0.01$; age $x$ exercise effect, $P<0.05$. Plasma insulin levels in the elderly at rest were significantly greater when compared with the other groups: $P<0.05$.

Plasma phenylalanine (A), tyrosine (B), isoleucine (C), leucine (D), and valine (E) concentrations over time are illustrated in Figure 2. In general, plasma amino acid concentrations increased over time and remained elevated throughout the $6 \mathrm{~h}$ postprandial phase. Plasma phenylalanine concentrations were significantly higher in the elderly compared with the young, irrespective of treatment $(P<0.05)$. Plasma leucine concentrations were significantly higher in the elderly at rest compared 
with the other groups $(\mathrm{P}<0.05)$. Additionally, plasma leucine concentrations were significantly lower in the young after exercise compared with the young at rest and the elderly after exercise $(P<0.05)$.

phenylalanine

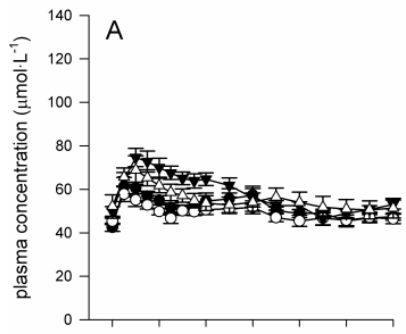

leucine

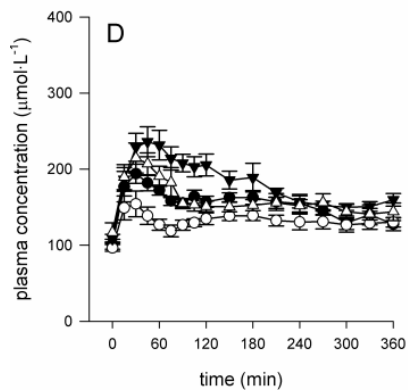

tyrosine

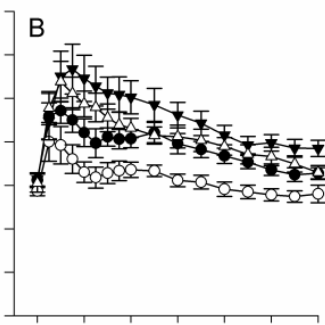

valine

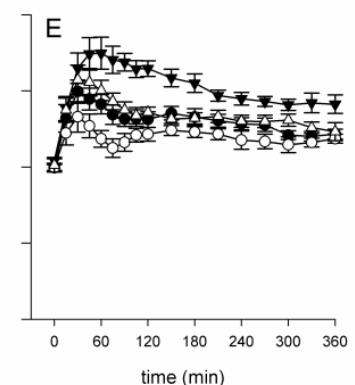

isoleucine

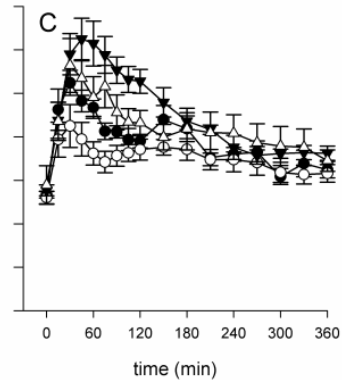

Figure 2. Postprandial plasma phenylalanine (A), tyrosine (B), isoleucine $(C)$, leucine $(D)$, and valine $(E)$ concentrations $\left(\mu \mathrm{mol} \cdot \mathrm{L}^{-1}\right)$ following protein ingestion in young $(n=24)$ and elderly $(n=24)$ men at rest (REST) and following exercise (EXC). Values represent means \pm SEM. Data were analyzed with mixed model repeated measures ANOVA. In case of a significant interaction between age and exercise, a Bonferroni post-hoc test was applied to locate these differences. Phenylalanine: time effect, $\mathrm{P}<0.01$; age $x$ exercise effect, $\mathrm{P}<0.01$; Elderly EXC vs Young EXC, $\mathrm{P}<0.01$; Elderly EXC vs Young REST, $\mathrm{P}<0.05$; Elderly REST vs Young EXC, $P<0.01$; Elderly REST vs Young REST, $P<0.01$. Tyrosine: time effect, $P<0.01$; age $X$ exercise effect, $\mathrm{P}<0.01$; Elderly EXC vs Young EXC, $\mathrm{P}<0.01$; Elderly REST vs Young EXC, $\mathrm{P}<0.01$; Elderly REST vs Young REST, $P<0.05$; Young EXC vs Young REST, $P<0.01$. Isoleucine: time effect, $P<0.01$; age $x$ exercise effect, $\mathrm{P}<0.01$; Elderly EXC vs Young EXC, $\mathrm{P}<0.01$; Elderly REST vs Young EXC, $\mathrm{P}<0.01$; Elderly REST vs Young REST, $\mathrm{P}<0.01$. Leucine: time effect, $\mathrm{P}<0.01$; age $\mathrm{x}$ exercise effect, $\mathrm{P}<0.01$; Elderly EXC vs Elderly REST, $\mathrm{P}<0.05$; Elderly EXC vs Young EXC, $\mathrm{P}<0.01$; Elderly REST vs Young EXC, $\mathrm{P}<0.01$; Elderly REST vs Young REST, $P<0.01$; Young EXC vs Young REST, $P<0.05$. Valine: time effect, $P<0.01$; age $x$ exercise effect, $\mathrm{P}<0.01$; Elderly EXC vs Elderly REST, $\mathrm{P}<0.01$; Elderly EXC vs Young EXC, $\mathrm{P}<0.05$; Elderly REST vs Young EXC, $\mathrm{P}<0.01$; Elderly REST vs Young REST, $\mathrm{P}<0.01$.

The time course of plasma L- $\left[1-{ }^{13} \mathrm{C}\right]$ phenylalanine (ingested tracer) and L-[ring${ }^{2} \mathrm{H}_{5}$ ]phenylalanine (infused tracer) enrichments are shown in Figure 3. Plasma L-[1${ }^{13} \mathrm{C}$ ]phenylalanine enrichments increased immediately following protein ingestion in all subjects, with no significant differences between groups. Plasma L-[ring- 
${ }^{2} \mathrm{H}_{5}$ ]phenylalanine enrichments were significantly higher in the elderly compared with the young, irrespective of treatment $(P<0.01)$. This was expected as isotope tracers were administered based on body weight and not lean body mass, the latter of which differs significantly between the young and elderly subjects (Table 1: $\mathrm{P}<0.05)$.

L-[1- ${ }^{13}$ C]phenylalanine

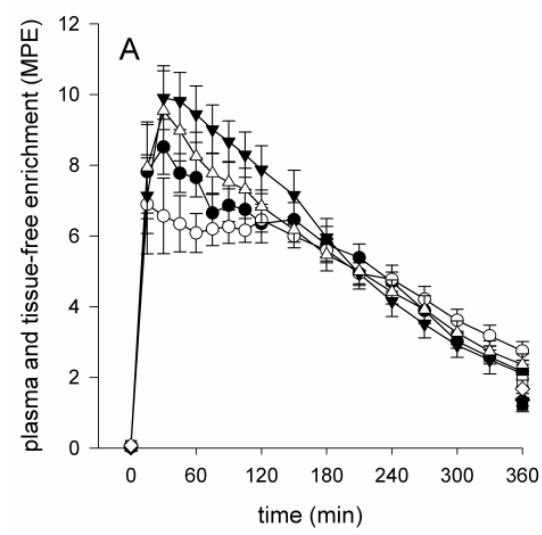

L-[ring- ${ }^{2} \mathrm{H}_{5}$ ]phenylalanine

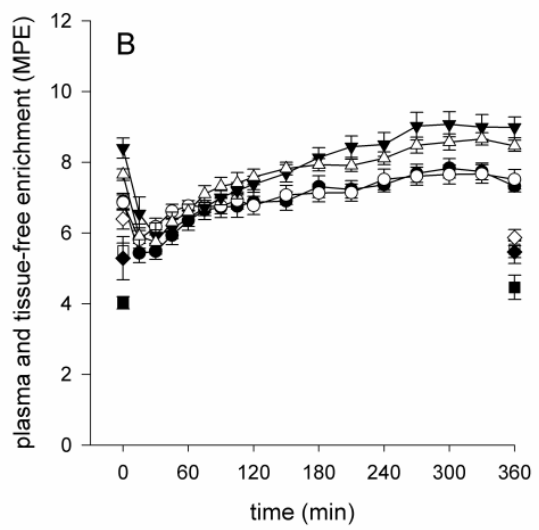

\footnotetext{
-- Young REST plasma

- - Young EXC plasma

$\triangle$ Elderly EXC plasma

- Young REST tissue-free

- Elderly REST tissue-free

$\checkmark$ Elderly EXC tissue-free
}

Figure 3. Plasma and tissue-free $L-\left[1-{ }^{13} \mathrm{C}\right]$ phenylalanine (A) and L-[ring- $\left.{ }^{2} \mathrm{H}_{5}\right]$ phenylalanine (B) enrichments (MPE) following protein ingestion in young $(n=24)$ and elderly $(n=24)$ men at rest (REST) and following exercise (EXC). Values represent means \pm SEM. Data were analyzed with mixed model repeated measures ANOVA. In case of a significant interaction between age and exercise, a Bonferroni post-hoc test was applied to locate these differences. Plasma $L-\left[1-{ }^{13} \mathrm{C}\right]$ phenylalanine enrichment: time effect, $P<0.01$; age $x$ exercise effect, $P=0.24$. Tissue-free $L-\left[1{ }^{13} C\right]$ phenylalanine enrichment: time effect, $P<0.001$; age effect, $P=0.64$; exercise effect, $P<0.05$; age $x$ exercise effect, $P=0.24$. Plasma L-[ring${ }^{2} \mathrm{H}_{5}$ ]phenylalanine enrichment: time effect, $\mathrm{P}<0.01$; age $x$ exercise effect, $\mathrm{P}<0.01$; Elderly EXC vs Young EXC, $\mathrm{P}<0.01$; Elderly EXC vs Young REST, $\mathrm{P}<0.01$; Elderly REST vs Young EXC, $\mathrm{P}<0.01$; Elderly REST vs Young REST, $\mathrm{P}<0.01$. Tissue-free $\mathrm{L}-\left[\right.$ ring $^{2}{ }^{2} \mathrm{H}_{5}$ ] phenylalanine: time effect, $\mathrm{P}=0.80$; age effect, $\mathrm{P}<0.05$; exercise effect, $\mathrm{P}<0.01$; age $\mathrm{x}$ exercise effect, $\mathrm{P}=0.47$.

\section{Whole-body plasma tracer kinetics}

Whole-body plasma tracer kinetics, expressed per kg lean body mass (LBM), are presented in Figure 4. Total phenylalanine rates of appearance decreased (Figure $4 \mathrm{~A}$ ) and total phenylalanine rates of disappearance increased (Figure 4B) during the $6 \mathrm{~h}$ postprandial period in the young and elderly, both at rest and following exercise. Total phenylalanine rates of appearance and disappearance were lower in the elderly when compared with the young, irrespective of treatment $(P<0.05)$. The plasma rates of appearance of exogenous phenylalanine rapidly increased following 
protein ingestion and slowly returned to baseline values during the $6 \mathrm{~h}$ postprandial period (Figure 4C). This response over time was similar for all groups.

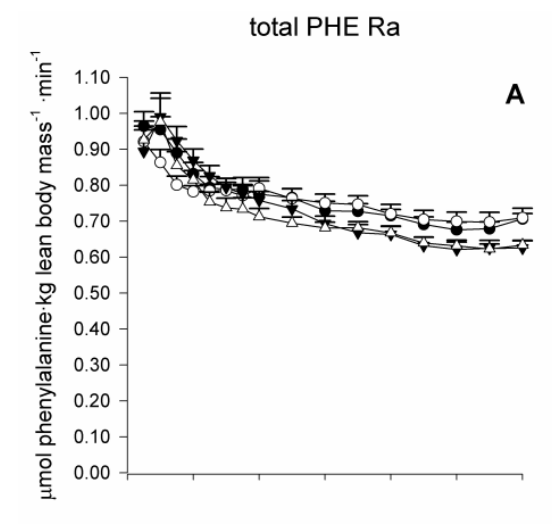

total PHE Rd

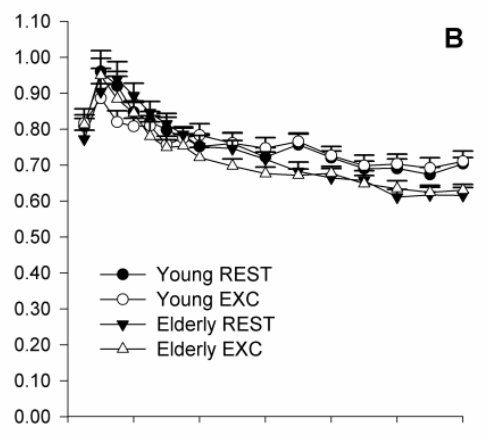

exogenous PHE Ra

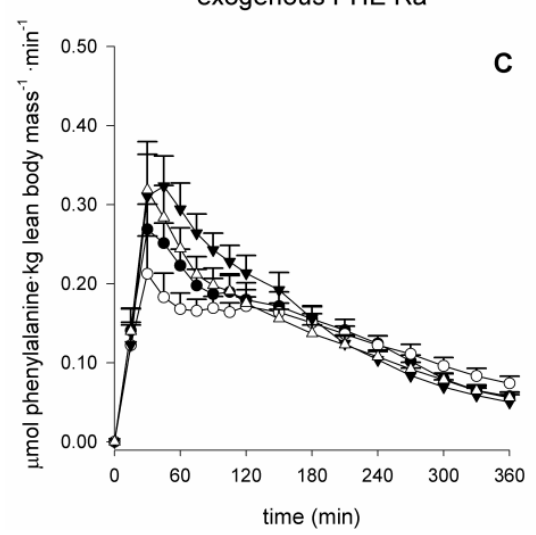

endogenous PHE Ra

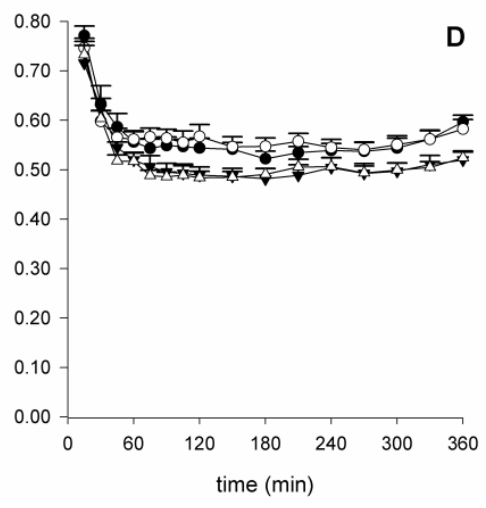

Figure 4. Whole-body plasma phenylalanine (PHE) kinetics expressed per kg lean body mass. (A) Total PHE rate of appearance $\left(R_{a}\right)$, (B) total PHE rate of disappearance $\left(R_{d}\right),(C)$ exogenous PHE $R_{a}$, and (D) endogenous PHE $R_{a}$ in $\mu \mathrm{mol} \cdot \mathrm{kg}$ lean body $\mathrm{mass}^{-1} \cdot \mathrm{min}^{-1}$ following protein ingestion in young $(n=24)$ and elderly $(n=24)$ men at rest (REST) and following exercise (EXC). Values represent means \pm SEM. Data were analyzed with mixed model repeated measures ANOVA. In case of a significant interaction between age and exercise, a Bonferroni post-hoc test was applied to locate these differences. Total PHE $R_{a}$ : time effect, $\mathrm{P}<0.01$; age $\mathrm{x}$ exercise effect, $\mathrm{P}<0.05$; Elderly EXC vs Young EXC, $\mathrm{P}<0.05$; Elderly EXC vs Young REST, $P<0.05$; Elderly REST vs Young EXC, $P<0.05$; Elderly REST vs Young REST, $P<0.05$. Total $P H E R_{d}$ : time effect, $\mathrm{P}<0.01$; age $\mathrm{x}$ exercise effect, $\mathrm{P}<0.05$; Elderly EXC vs Young EXC, $\mathrm{P}<0.05$; Elderly EXC vs Young REST, $\mathrm{P}<0.05$; Elderly REST vs Young EXC, $\mathrm{P}<0.05$; Elderly REST vs Young REST, $\mathrm{P}<0.05$. Exogenous $\mathrm{R}_{\mathrm{a}}$ : time effect, $P<0.01$; age $x$ exercise effect, $P=0.87$. Endogenous $R_{a}$ : time effect, $P<0.01$; age $x$ exercise effect, $\mathrm{P}<0.05$; Elderly EXC vs Young EXC, $\mathrm{P}<0.05$; Elderly EXC vs Young REST, $\mathrm{P}<0.05$; Elderly REST vs Young EXC, $\mathrm{P}<0.05$; Elderly REST vs Young REST, $\mathrm{P}<0.05$.

The calculated percentage of ingested phenylalanine that appeared in the circulation during the $6 \mathrm{~h}$ postprandial period, was $52 \pm 2$ and $50 \pm 2 \%$ in the young and 
$52 \pm 2$ and $49 \pm 2 \%$ in the elderly group, at rest and following exercise, respectively. No differences were observed between groups $(P=0.87)$. Total endogenous rates of phenylalanine appearance declined following protein ingestion and remained below baseline values during the $6 \mathrm{~h}$ postprandial period (Figure 4D). The average endogenous phenylalanine appearance rates were lower in the elderly compared with the young, irrespective of treatment $(P<0.05)$.

\section{Muscle tracer analysis}

Tissue-free enrichments (MPE), determined in the muscle samples collected at 0 and $6 \mathrm{~h}$ following dietary protein ingestion, are presented in Table $\mathbf{2}$ and included in Figure 3. Tissue-free enrichments were higher following EXC compared with REST for both $L-\left[1-{ }^{13} \mathrm{C}\right]$ phenylalanine $(\mathrm{P}<0.05)$ and $\mathrm{L}-\left[\right.$ ring- $\left.{ }^{2} \mathrm{H}_{5}\right]$ phenylalanine $(\mathrm{P}<0.01)$. Tissue-free $\mathrm{L}$-[ring- ${ }^{2} \mathrm{H}_{5}$ ] phenylalanine enrichments showed a significant age effect $(\mathrm{P}<0.05)$. No significant differences in $\mathrm{L}-\left[\right.$ ring $\left._{-}{ }^{2} \mathrm{H}_{5}\right]$ phenylalanine enrichments over time were observed $(P=0.80)$.

Table 2. Muscle tissue-free enrichments.

\begin{tabular}{lcccc}
\hline & $\begin{array}{c}\text { Young } \\
\text { REST } \\
(\mathrm{n}=12)\end{array}$ & $\begin{array}{c}\text { Young } \\
\text { EXC } \\
(\mathrm{n}=12)\end{array}$ & $\begin{array}{c}\text { Elderly } \\
\text { REST } \\
(\mathrm{n}=12)\end{array}$ & $\begin{array}{c}\text { Elderly } \\
\text { EXC }\end{array}$ \\
\hline $\mathrm{Oh} \mathrm{L}-\left[1-{ }^{13} \mathrm{C}\right]$ phenylalanine (MPE) & $0.06 \pm 0.05$ & $0.05 \pm 0.02$ & $0.01 \pm 0.05$ & $0.07 \pm 0.03$ \\
$6 \mathrm{~h} \mathrm{~L}-\left[1-{ }^{13} \mathrm{C}\right]$ phenylalanine (MPE) & $1.22 \pm 0.20$ & $1.91 \pm 0.19$ & $1.28 \pm 0.15$ & $1.67 \pm 0.25$ \\
$0 \mathrm{~h} \mathrm{~L}-\left[\right.$ ring $\left.-{ }^{2} \mathrm{H}_{5}\right]$ phenylalanine (MPE) & $4.02 \pm 0.18$ & $5.49 \pm 0.22$ & $5.28 \pm 0.61$ & $6.39 \pm 0.29$ \\
$6 \mathrm{~h} \mathrm{~L}-\left[\right.$ ring- $\left.{ }^{2} \mathrm{H}_{5}\right]$ phenylalanine (MPE) & $4.46 \pm 0.34$ & $5.54 \pm 0.23$ & $5.46 \pm 0.33$ & $5.87 \pm 0.23$ \\
\hline
\end{tabular}

Values are expressed as means \pm SEM. Data were analyzed with repeated measures mixed model ANOVA (age $x$ exercise). $\mathrm{L}-\left[1-{ }^{13} \mathrm{C}\right.$ ]phenylalanine: time effect, $\mathrm{P}<0.001$; age effect, $\mathrm{P}=0.64$; exercise effect, $\mathrm{P}<0.05$; interaction age $x$ exercise, $\mathrm{P}=0.24$. $\mathrm{L}-\left[\mathrm{ring}_{-}{ }^{2} \mathrm{H}_{5}\right.$ ]phenylalanine: time effect, $\mathrm{P}=0.80$; age effect, $\mathrm{P}<0.05$; exercise effect, $\mathrm{P}<0.01$; interaction age $\mathrm{x}$ exercise, $\mathrm{P}=0.47$.

Protein-bound labeled phenylalanine enrichments during the $6 \mathrm{~h}$ post-prandial period are presented as pooled data for either young and elderly or REST and EXC. The protein-bound enrichments were higher following EXC compared with REST for both L-[1- $\left.{ }^{13} \mathrm{C}\right]$ phenylalanine $(0.022 \pm 0.005$ vs $0.019 \pm 0.005 \mathrm{MPE} ; \mathrm{P}<0.05)$ and L-[ring${ }^{2} \mathrm{H}_{5}$ ]phenylalanine $(0.024 \pm 0.004$ vs $0.020 \pm 0.005 \mathrm{MPE} ; \mathrm{P}<0.01)$. No significant differences were observed between age-groups.

\section{Mixed muscle protein synthesis rates}

Mixed muscle protein synthesis rates, expressed as fractional synthetic rates (FSR), are presented in Figure 5. Statistical testing was performed using ANOVA (age $x$ exercise). As such, mean values $( \pm S E M)$ presented below represent pooled data for either the young and elderly or REST and EXC. 
L- $\left[1-{ }^{13} \mathrm{C}\right]$ phenylalanine

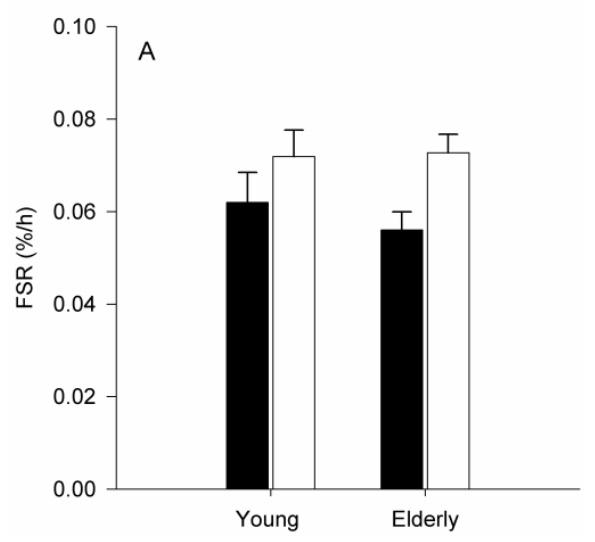

L-[ring- $\left.{ }^{2} \mathrm{H}_{5}\right]$ phenylalanine

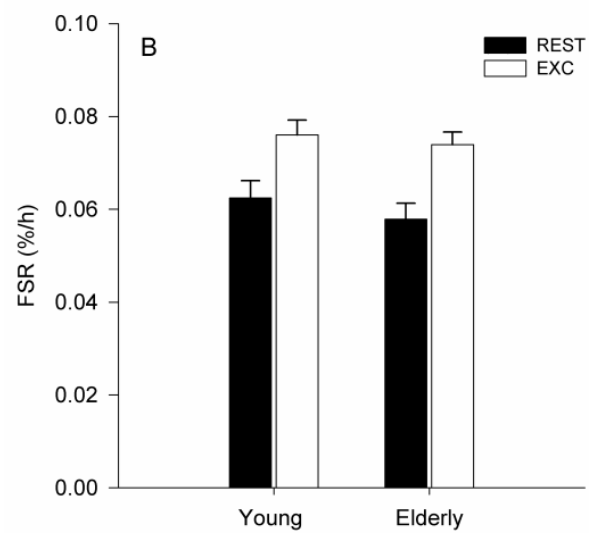

Figure 5. Mixed muscle protein fractional synthetic rates (FSR) following protein ingestion in young $(n=24)$ and elderly $(n=24)$ men at rest (REST) and following exercise (EXC) based on (A) L-[1${ }^{13} \mathrm{C}$ ]phenylalanine (ingested tracer) enrichment and (B) L-[ring $\left.-{ }^{2} \mathrm{H}_{5}\right]$ phenylalanine (infused tracer) enrichment. Values represent means \pm SEM. Data were analyzed with ANOVA (age $x$ exercise). L-[1${ }^{13} \mathrm{C}$ ] phenylalanine enrichment: age effect, $\mathrm{P}=0.62$; exercise effect, $\mathrm{P}<0.05$; age $\mathrm{x}$ exercise effect, $\mathrm{P}=0.52$. L-[ring ${ }^{2}{ }^{2}$ ] phenylalanine enrichment: age effect, $\mathrm{P}=0.32$; exercise effect, $\mathrm{P}<0.001$; age $\mathrm{x}$ exercise effect, $\mathrm{P}=0.70$.

Mixed muscle protein FSR based on L-[1- $\left.{ }^{13} \mathrm{C}\right]$ phenylalanine, with the mean plasma $\mathrm{L}-\left[1-{ }^{13} \mathrm{C}\right]$ phenylalanine enrichment as precursor, were significantly higher with EXC compared with REST $\left(0.0723 \pm 0.0034\right.$ vs $0.0590 \pm 0.0037 \% \cdot h^{-1}$, respectively; $\left.\mathrm{P}<0.05\right)$ in both the young $(+16 \%)$ and elderly $(+30 \%)$. In agreement, using the L-[ring-

${ }^{2} \mathrm{H}_{5}$ ]phenylalanine tracer, FSR values also showed significantly higher values following EXC compared with REST $\left(0.0750 \pm 0.0020\right.$ vs $0.0602 \pm 0.0025 \% \cdot \mathrm{h}^{-1}$, respectively; $\mathrm{P}<0.001)$ in both the young $(+22 \%)$ and elderly $(+28 \%)$. No significant differences were observed between age-groups.

\section{Discussion}

In the present study, dietary protein digestion and absorption kinetics and subsequent postprandial muscle protein synthesis rates were compared at rest and following exercise between healthy, young and elderly males. The appearance of phenylalanine from the ingested protein into the circulation ( $50 \%)$ did not differ between rest and exercise or between the young and elderly. Postprandial muscle protein synthesis rates calculated from both the ingested and infused tracer were higher following exercise when compared with resting conditions and were independent of age.

It has recently been reported that the acute muscle protein synthetic response to the main anabolic stimuli, i.e. food intake $(5,7,12)$ and exercise $(11)$, is blunted in 
the elderly. This blunted anabolic response has been suggested to represent a keyfactor in the etiology of sarcopenia. Following protein ingestion, a rapid increase in plasma amino acid concentrations was observed in both age-groups, with higher concentrations in the elderly compared with the young (Figure 2). These differences are, at least partly, attributed to the fact that dietary protein was administered based on body weight and not lean body mass, which was significantly lower in the elderly (Table 1). However, even when corrected for differences in lean body mass, whole-body phenylalanine turnover rates remained lower in the elderly when compared with the young (Figure $4 \mathrm{AB}$ ). These observations are consistent with previous work applying phenylalanine as tracer (17, 30-32).

To allow true insight into in vivo dietary protein digestion and absorption kinetics, we combined the use of specifically produced intrinsically $\mathrm{L}-\left[1-{ }^{13} \mathrm{C}\right]$ phenylalaninelabeled protein with continuous intravenous infusion of L-[ring- ${ }^{2} \mathrm{H}_{5}$ ]phenylalanine. We observed that approximately half of the dietary protein-derived amino acids became available in the circulation over the $6 \mathrm{~h}$ postprandial period in all groups. This is in line with previous work in humans (26) and pigs (33), showing that the splanchnic area extracts about $50 \%$ of the ingested amino acids to sustain its functional mass. Consequently, our data show that dietary protein digestion and absorption kinetics are not impaired at a more advanced age and remain unchanged when exercise is performed prior to protein ingestion.

Following dietary protein ingestion, changes in protein metabolism became directly apparent on a whole-body level. Exogenous phenylalanine appearance rates increased immediately (Figure 4C), whereas endogenous phenylalanine appearance rates (i.e. whole-body protein breakdown) were rapidly reduced (Figure 4D). These findings are consistent with previous work $(17,28,34)$ and are indicative of a more anabolic situation. Endogenous phenylalanine appearance rates were lower in the elderly when compared with the young (Figure 4D). However, this does not indicate that postprandial inhibition of whole-body protein breakdown was attenuated in the elderly, as basal whole-body protein turnover rates are generally $\sim 20 \%$ lower in the elderly when compared with the young $(30,31)$. As changes in protein metabolism on a whole-body level do not necessarily represent changes on a muscle level (35), we determined the incorporation of $\mathrm{L}-\left[1-{ }^{13} \mathrm{C}\right]$ phenylalanine into mixed muscle protein. The fact that tracer incorporation did not differ between the young and the elderly demonstrated that a similar amount of dietary protein-derived amino acids was incorporated in newly synthesized skeletal muscle protein in both age-groups over the $6 \mathrm{~h}$ postprandial period. Though no differences were observed between the young and the elderly, substantial differences in the incorporation of $\mathrm{L}-\left[1-{ }^{13} \mathrm{C}\right]$ phenylalanine in newly synthesized skeletal muscle protein were observed between resting and post-exercise conditions $(P<0.05)$. We extend on previous findings $(6,29,36,37)$ with the observation that significantly more of the ingested protein-derived amino acids were incorporated in newly synthesized skeletal mus- 
cle protein over the $6 \mathrm{~h}$ postprandial period when exercise was performed before food intake. Postprandial muscle protein fractional synthetic rates (FSR) based on the oral $\mathrm{L}-\left[1-{ }^{13} \mathrm{C}\right]$ phenylalanine tracer were higher following exercise when compared with rest (Figure 5A; $\mathrm{P}<0.05$ ). Similar findings were obtained when FSR were calculated based on the intravenous L-[ring- $\left.{ }^{2} \mathrm{H}_{5}\right]$-phenylalanine tracer (Figure 5B; $\mathrm{P}<0.001$ ). The reported FSR values may seem relatively small (Figure 5), but are attributed to the fact that we applied a relatively long incorporation period, required to accurately assess in vivo casein digestion and absorption kinetics, and used plasma phenylalanine enrichments as precursor to calculate muscle protein synthesis rates (38). Though we observed a significant correlation between plasma and muscle tissue-free precursor enrichments at $6 \mathrm{~h}$ after dietary protein ingestion, there are no data available on the relationship between plasma and muscle precursor enrichments throughout the entire postprandial period. Therefore, we can only speculate on potential differences in tracer equilibration in plasma and muscle tissue between the young and elderly. As such, we cannot exclude the presence of diversities in tracer equilibration in plasma and muscle tissue between age-groups. Nonetheless, it should be noted that all subjects ingested the same amount of intrinsically labeled protein and that more of the ingested tracer had been incorporated in mixed muscle protein following $6 \mathrm{~h}$ of post-exercise recovery when compared with resting conditions, with no significant differences between age-groups. Our findings seem to be in contrast with studies suggesting that the muscle protein synthetic response to amino acid administration $(5,12)$ and exercise $(11)$ may be blunted in the elderly. Those authors measured postprandial muscle protein synthesis with insulin levels clamped $(5,12)$ or assessed post-exercise muscle protein synthesis in the absence of amino acid administration (11). In contrast, we assessed the muscle protein synthetic response under normal living conditions, i.e. following ingestion of a single meal-like amount of protein. Ingestion of the protein bolus resulted in a rapid increase in plasma amino acid availability (Figures 2 and 4), accompanied by a rapid, but short-lived, postprandial peak in circulating insulin (Figure 1). The latter is relevant to facilitate nutritive blood flow which supports protein synthesis by increasing amino acid availability to the muscle (39).

Though similar postprandial FSR values were reported, the elderly showed greater plasma insulin responses (Figure 1) and higher circulating plasma amino acid concentrations (Figure 2) compared with the younger controls. The greater plasma insulin response and more rapid rise in postprandial plasma amino acid concentrations in the elderly may represent a compensatory mechanism to maintain a proper postprandial muscle protein synthetic response and, as such, could be regarded as an early stage of anabolic resistance. However, the higher plasma amino acid concentrations can be, at least partly, attributed to the fact that all subjects were provided with the same amount of dietary protein. As subjects were matched for body weight, the lower lean body mass in the elderly might be accompanied by 
lower whole-body insulin sensitivity and/or a reduced distribution volume for phenylalanine. Correcting the distribution volume for the lower lean body mass ( 8\%) did not result in significant changes in whole-body phenylalanine kinetics (data not shown). This is in line with previous observations by Boirie et al. (15).

Effective dietary strategies are needed to prevent and/or attenuate the age-related loss of muscle mass. The present study provides novel data to show that 1 ) dietary protein digestion and absorption kinetics are not impaired following exercise or at older age; and 2) exercising before protein intake allows for a greater use of dietary protein-derived amino acids for de novo muscle protein synthesis in both young and elderly men. Clearly, exercise and/or physical activity should be considered an important tool to improve postprandial muscle protein accretion and, as such, to treat sarcopenia and support healthy aging.

\section{Acknowledgements}

We gratefully acknowledge the assistance of Ernst Fluitman and Antoine Zorenc in performing the experiments and the enthusiastic support of the subjects who volunteered to participate in these experiments.

The authors' responsibilities were as follows - BP, RK, and LJCVL designed the study; BP organized and carried out the clinical experiments with the assistance of MB and JMGS; JMGS performed the stable isotope analyses; BP performed the (statistical) analysis of the data and wrote the manuscript together with LJCVL, RK and WHMS; and MB and WHMS provided medical assistance. None of the authors had a personal or financial conflict of interest. 


\section{References}

1. Evans WJ. What is sarcopenia? J Gerontol A Biol Sci Med Sci 1995;50 Spec No:5-8.

2. Welle S, Thornton C, Jozefowicz R, Statt M. Myofibrillar protein synthesis in young and old men. Am J Physiol 1993;264:E693-8.

3. Balagopal P, Rooyackers OE, Adey DB, Ades PA, Nair KS. Effects of aging on in vivo synthesis of skeletal muscle myosin heavy-chain and sarcoplasmic protein in humans. Am J Physiol 1997;273:E790-800.

4. Volpi E, Sheffield-Moore M, Rasmussen BB, Wolfe RR. Basal muscle amino acid kinetics and protein synthesis in healthy young and older men. JAMA 2001;286:1206-12.

5. Cuthbertson D, Smith K, Babraj J, et al. Anabolic signaling deficits underlie amino acid resistance of wasting, aging muscle. FASEB J 2005;19:422-4.

6. Tang JE, Moore DR, Kujbida GW, Tarnopolsky MA, Phillips SM. Ingestion of whey hydrolysate, casein, or soy protein isolate: effects on mixed muscle protein synthesis at rest and following resistance exercise in young men. J Appl Physiol 2009;107:987-92.

7. Katsanos CS, Kobayashi H, Sheffield-Moore M, Aarsland A, Wolfe RR. Aging is associated with diminished accretion of muscle proteins after the ingestion of a small bolus of essential amino acids. Am J Clin Nutr 2005;82:1065-73.

8. Phillips SM, Tipton KD, Aarsland A, Wolf SE, Wolfe RR. Mixed muscle protein synthesis and breakdown after resistance exercise in humans. Am J Physiol 1997;273:E99-107.

9. Biolo G, Maggi SP, Williams BD, Tipton KD, Wolfe RR. Increased rates of muscle protein turnover and amino acid transport after resistance exercise in humans. Am J Physiol 1995;268:E514-20.

10. Chesley A, MacDougall JD, Tarnopolsky MA, Atkinson SA, Smith K. Changes in human muscle protein synthesis after resistance exercise. J Appl Physiol 1992;73:1383-8.

11. Kumar V, Selby A, Rankin D, et al. Age-related differences in the dose-response relationship of muscle protein synthesis to resistance exercise in young and old men. J Physiol 2009;587:211-7.

12. Guillet $C$, Prod'homme M, Balage $M$, et al. Impaired anabolic response of muscle protein synthesis is associated with S6K1 dysregulation in elderly humans. FASEB J 2004;18:1586-7.

13. Koopman R, van Loon L. Aging, exercise and muscle protein metabolism. J Appl Physiol 2009.

14. Boirie Y, Gachon P, Beaufrere B. Splanchnic and whole-body leucine kinetics in young and elderly men. Am J Clin Nutr 1997;65:489-95.

15. Boirie Y, Gachon P, Corny S, Fauquant J, Maubois JL, Beaufrere B. Acute postprandial changes in leucine metabolism as assessed with an intrinsically labeled milk protein. Am J Physiol 1996;271:E1083-91.

16. van Loon $\mathrm{L}$, Boirie $\mathrm{Y}$, Gijsen $\mathrm{AP}$, et al. The production of intrinsically labeled milk protein provides a functional tool for human nutrition research. J Dairy Sci 2009;92:4812-22.

17. Koopman R, Walrand S, Beelen $\mathrm{M}$, et al. Dietary protein digestion and absorption rates and the subsequent postprandial muscle protein synthetic response do not differ between young and elderly men. J Nutr 2009;139:1707-13.

18. Moore DR, Robinson MJ, Fry JL, et al. Ingested protein dose response of muscle and albumin protein synthesis after resistance exercise in young men. Am J Clin Nutr 2009;89:161-8.

19. Verdijk LB, Jonkers RA, Gleeson BG, et al. Protein supplementation before and after exercise does not further augment skeletal muscle hypertrophy after resistance training in elderly men. Am J Clin Nutr 2009;89:608-16.

20. Alberti KG, Zimmet PZ. Definition, diagnosis and classification of diabetes mellitus and its complications. Part 1: diagnosis and classification of diabetes mellitus provisional report of a WHO consultation. Diabet Med 1998;15:539-53.

21. Mayhew JL, Prinster JL, Ware JS, Zimmer DL, Arabas JR, Bemben MG. Muscular endurance repetitions to predict bench press strength in men of different training levels. J Sports Med Phys Fitness 1995;35:108-13. 
22. Abumrad NN, Rabin D, Diamond MP, Lacy WW. Use of a heated superficial hand vein as an alternative site for the measurement of amino acid concentrations and for the study of glucose and alanine kinetics in man. Metabolism 1981;30:936-40.

23. Bergstrom J. Percutaneous needle biopsy of skeletal muscle in physiological and clinical research. Scand J Clin Lab Invest 1975;35:609-16.

24. van Eijk HM, Rooyakkers DR, Deutz NE. Rapid routine determination of amino acids in plasma by high-performance liquid chromatography with a 2-3 microns Spherisorb ODS II column. J Chromatogr 1993;620:143-8.

25. Wolfe RR. Radioactive and stable isotope tracers in biomedicine: principles and practice of kinetic analysis. New York: Wiley-Liss 1992.

26. Biolo $G$, Tessari $P$, Inchiostro $S$, et al. Leucine and phenylalanine kinetics during mixed meal ingestion: a multiple tracer approach. Am J Physiol 1992;262:E455-63.

27. Husek P. Amino acid derivatization and analysis in five minutes. FEBS Lett 1991;280:354-6.

28. Dangin M, Guillet C, Garcia-Rodenas C, et al. The rate of protein digestion affects protein gain differently during aging in humans. J Physiol 2003;549:635-44.

29. Koopman R, Wagenmakers AJ, Manders RJ, et al. Combined ingestion of protein and free leucine with carbohydrate increases postexercise muscle protein synthesis in vivo in male subjects. Am J Physiol Endocrinol Metab 2005;288:E645-53.

30. Short KR, Vittone JL, Bigelow ML, Proctor DN, Nair KS. Age and aerobic exercise training effects on whole body and muscle protein metabolism. Am J Physiol Endocrinol Metab 2004;286:E92-101.

31. Henderson GC, Dhatariya K, Ford GC, et al. Higher muscle protein synthesis in women than men across the lifespan, and failure of androgen administration to amend age-related decrements. FASEB J 2009;23:631-41.

32. Koopman R, Verdijk L, Manders RJ, et al. Co-ingestion of protein and leucine stimulates muscle protein synthesis rates to the same extent in young and elderly lean men. Am J Clin Nutr 2006;84:623-32.

33. Deutz NE, Bruins MJ, Soeters PB. Infusion of soy and casein protein meals affects interorgan amino acid metabolism and urea kinetics differently in pigs. J Nutr 1998;128:2435-45.

34. Koopman R, Crombach N, Gijsen AP, et al. Ingestion of a protein hydrolysate is accompanied by an accelerated in vivo digestion and absorption rate when compared with its intact protein. Am J Clin Nutr 2009;90:106-15.

35. Nair KS, Halliday D, Griggs RC. Leucine incorporation into mixed skeletal muscle protein in humans. Am J Physiol 1988;254:E208-13.

36. Tipton KD, Ferrando AA, Phillips SM, Doyle D, Jr., Wolfe RR. Post-exercise net protein synthesis in human muscle from orally administered amino acids. Am J Physiol 1999;276:E628-34.

37. Biolo G, Tipton KD, Klein S, Wolfe RR. An abundant supply of amino acids enhances the metabolic effect of exercise on muscle protein. Am J Physiol 1997;273:E122-9.

38. Ljungqvist $\mathrm{OH}$, Persson M, Ford GC, Nair KS. Functional heterogeneity of leucine pools in human skeletal muscle. Am J Physiol 1997;273:E564-70.

39. Clark MG, Rattigan S, Barrett EJ. Nutritive blood flow as an essential element supporting muscle anabolism. Curr Opin Clin Nutr Metab Care 2006;9:185-9. 



\section{Chapter 3}

\section{Whey protein stimulates postprandial muscle protein accretion more effectively than do casein and casein hydrolysate in older men}

American Journal of Clinical Nutrition 2011 May;93(5):997-1005 


\begin{abstract}
Differences in digestion and absorption kinetics of dietary protein and/or its amino acid composition have been suggested to modulate postprandial muscle protein accretion. In the present study, we compared protein digestion and absorption kinetics and subsequent postprandial muscle protein accretion following ingestion of whey, casein, and casein hydrolysate in healthy, older adults. A total of 48 older men ( $74 \pm 1 \mathrm{y}$ ) were randomly assigned to ingest a meal-like amount ( $20 \mathrm{~g}$ ) of intrinsically L-[1- $\left.{ }^{13} \mathrm{C}\right]$ phenylalanine-labeled whey (WHEY), casein (CAS), or casein hydrolysate (CASH). Protein ingestion was combined with continuous intravenous L-[ring- ${ }^{2} \mathrm{H}_{5}$ ]phenylalanine infusion to assess in vivo digestion and absorption kinetics of dietary protein. Postprandial mixed muscle protein fractional synthetic rates (FSR) were calculated from the ingested tracer. The peak appearance rate of dietary protein-derived phenylalanine in the circulation was greater with WHEY and CASH when compared with CAS $(P<0.05)$. FSR values were higher following WHEY $\left(0.15 \pm 0.02 \% \cdot \mathrm{h}^{-1}\right)$ compared with CAS $\left(0.08 \pm 0.01 \% \cdot \mathrm{h}^{-1} ; \mathrm{P}<0.01\right)$ and CASH $\left(0.10 \pm 0.01 \% \cdot h^{-1} ; P<0.05\right)$ ingestion. Peak plasma leucine concentrations and postprandial FSR values showed a strong positive correlation $(r=0.66 ; P<0.01)$.

In conclusion, whey protein stimulates postprandial muscle protein accretion more effectively than do casein and casein hydrolysate in older men. This effect can be attributed to a combination of whey's faster digestion and absorption kinetics and higher leucine content.
\end{abstract}




\section{Introduction}

Aging is accompanied by a progressive decline in skeletal muscle mass, termed sarcopenia (1). Recently, data have been obtained to suggest that the skeletal muscle protein synthetic response to food intake is impaired in older adults (2-5). This proposed anabolic resistance is now regarded a key-factor in the etiology of sarcopenia.

Ingestion of a meal-like amount of protein in the form of free amino acids $(6,7)$, milk protein (8) or beef (9) strongly stimulates skeletal muscle protein synthesis rates. This postprandial muscle protein synthetic response depends on the quantity but, to some extent, also on the type of protein that is ingested (10). Previous work suggests that whey protein ingestion results in greater postprandial protein retention when compared with the ingestion of casein $(11,12)$. The greater anabolic properties of whey versus casein have been mainly attributed to the faster digestion and absorption kinetics of whey, resulting in a greater increase in postprandial plasma amino acid availability, thereby further stimulating muscle protein synthesis (13-16). These findings have led to the development of the "fast" versus "slow" protein concept $(13,14,17)$.

Besides differences in protein digestion and absorption kinetics, whey and casein also markedly differ in their amino acid composition $(13,14,16)$. Whereas both proteins contain all the amino acids required to effectively stimulate muscle protein synthesis (6), whey has a considerably higher leucine content $(13,14,16)$. The latter may also contribute to the proposed greater anabolic properties of whey compared with casein, as leucine has been identified as the main nutritional signal responsible for stimulating postprandial muscle protein accretion (18-21). Consequently, it remains to be elucidated whether the proposed greater anabolic properties of whey versus casein protein are attributed to faster digestion and absorption kinetics or simply due to differences in amino acid composition.

Recently, we observed that when intact casein is hydrolyzed, in vivo protein digestion and absorption kinetics can be modulated to resemble a fast protein while retaining its amino acid composition (17). This provides us with an important tool to define the characteristics responsible for the proposed anabolic properties of whey versus casein. Consequently, our objective was to compare protein digestion and absorption kinetics and subsequent postprandial muscle protein accretion following the ingestion of whey, intact casein, and hydrolyzed casein in older adults. As the metabolic fate of amino acids ingested as protein cannot be correctly assessed by oral or intravenous administration of labeled free amino acids $(11,22)$, we applied specifically produced intrinsically $\mathrm{L}-\left[1-{ }^{13} \mathrm{C}\right]$ phenylalanine-labeled milk proteins. Labeled milk proteins were obtained by infusing cows with large quantities of $\mathrm{L}-\left[1-{ }^{13} \mathrm{C}\right]$ phenylalanine, collecting milk, purifying the casein and whey fractions, and hydrolyzing part of the casein (23). 
This study provides insight in the characteristics that define the anabolic properties of different types of dietary protein under normal, physiological conditions in older adults by comparing dietary protein digestion and absorption kinetics and subsequent postprandial muscle protein accretion following the ingestion of $20 \mathrm{~g}$ whey, casein, and casein hydrolysate in vivo in 48 healthy, older men.

\section{Methods}

\section{Subjects}

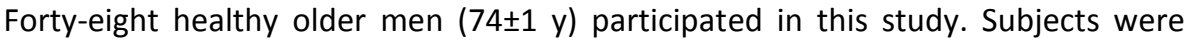
randomly assigned to ingest a single bolus of whey (WHEY), casein (CAS), or casein hydrolysate (CASH). Subjects' characteristics are presented in Table 1. None of the subjects participated in any regular exercise program or had a history of type 2 diabetes, though average $\mathrm{HbA1c}$ levels of 6.1-6.2 \% placed them in the prediabetes category (24). All subjects were informed on the nature and possible risk of the experimental procedures before their written informed consent was obtained. This study was approved by the Medical Ethics Committee of the Academic Hospital Maastricht.

\section{Pretesting}

Before selection in the study an oral glucose tolerance test (OGTT) was performed to assess glucose tolerance and screen for type 2 diabetes prevalence according to World Health Organization criteria (25). Prior to the OGTT, body weight and height were assessed and body composition was determined by dual-energy X-ray absorptiometry (DXA, Discovery A, Hologic Corporate, Bedford, MA, USA).

Table 1. Subjects' characteristics

\begin{tabular}{lccc}
\hline & $\begin{array}{c}\text { WHEY } \\
(\mathrm{n}=16)\end{array}$ & $\begin{array}{c}\text { CAS } \\
(\mathrm{n}=16)\end{array}$ & $\begin{array}{c}\text { CASH } \\
(\mathrm{n}=16)\end{array}$ \\
\hline Age $(\mathrm{yrs})$ & $73 \pm 1$ & $74 \pm 1$ & $74 \pm 1$ \\
Weight $(\mathrm{kg})$ & $75.9 \pm 1.5$ & $74.9 \pm 2.8$ & $76.4 \pm 1.5$ \\
BMI $\left(\mathrm{kg} \cdot \mathrm{m}^{-2}\right)$ & $25.4 \pm 0.4$ & $25.4 \pm 0.6$ & $25.0 \pm 0.7$ \\
Fat \% & $21.9 \pm 0.9$ & $20.6 \pm 0.9$ & $20.6 \pm 0.7$ \\
Lean body mass $(\mathrm{kg})$ & $59.2 \pm 1.2$ & $59.3 \pm 1.9$ & $60.7 \pm 1.3$ \\
HbA1c $(\%)$ & $6.2 \pm 0.1$ & $6.1 \pm 0.1$ & $6.1 \pm 0.1$ \\
OGTT $_{0}$ glucose $\left(\mathrm{mmol} \cdot \mathrm{L}^{-1}\right)$ & $5.7 \pm 0.1$ & $5.7 \pm 0.1$ & $5.8 \pm 0.2$ \\
OGTT $_{120}$ glucose $\left(\mathrm{mmol} \cdot \mathrm{L}^{-1}\right)$ & $6.1 \pm 0.3$ & $6.2 \pm 0.4$ & $6.4 \pm 0.4$ \\
\hline
\end{tabular}

Values are expressed as means \pm SEM. Oral glucose tolerance test (OGTT). Plasma glucose concentrations during basal, fasting conditions (OGTT $)$ and $120 \mathrm{~min}$ after ingestion of a 75-g glucose load (OGTT 120 ). Data were analyzed with ANOVA. No differences were observed between groups. 


\section{Diet and activity prior to testing}

All subjects consumed a standardized meal $\left(32 \pm 2 \mathrm{~kJ} \cdot \mathrm{kg}^{-1}\right.$ body weight, consisting of 55 energy\% (E\%) carbohydrate, $15 \mathrm{E} \%$ protein and $30 \mathrm{E} \%$ fat) the evening prior to the experiment. All volunteers were instructed to refrain from any sort of exhaustive physical activity and to keep their diet as constant as possible $3 \mathrm{~d}$ prior to the experiments.

\section{Experiments}

Each subject participated in a single $8 \mathrm{~h}$ experiment, in which a $20 \mathrm{~g}$ bolus of intrinsically L-[1- $\left.{ }^{13} \mathrm{C}\right]$ phenylalanine-labeled protein was ingested. Subjects ingested either WHEY, CAS, or CASH protein. Following the ingestion of the dietary protein, plasma and muscle samples were collected during a $6 \mathrm{~h}$ postprandial period. Ingestion of labeled protein was combined with continuous intravenous L-[ring${ }^{2} \mathrm{H}_{5}$ ]phenylalanine infusion to simultaneously assess exogenous and endogenous phenylalanine rates of appearance, dietary phenylalanine availability, and mixed muscle protein fractional synthetic rates (FSR) in vivo in humans.

\section{Protocol}

At 8.00 am, following an overnight fast, subjects arrived at the laboratory by car or public transportation. A Teflon catheter was inserted into an antecubital vein for stable isotope infusion. A second Teflon catheter was inserted in a heated dorsal hand vein of the contralateral arm and placed in a hot-box $\left(60^{\circ} \mathrm{C}\right)$ for arterialized blood sampling (26). Following basal blood collection ( $t=-120 \mathrm{~min}$ ), the plasma phenylalanine pool was primed with a single intravenous dose L-[ring${ }^{2} \mathrm{H}_{5}$ ]phenylalanine $\left(2 \mu \mathrm{mol} \cdot \mathrm{kg}^{-1}\right)$, after which continuous L-[ring- ${ }^{2} \mathrm{H}_{5}$ ]phenylalanine infusion was started $\left(0.050 \pm 0.001 \mu \mathrm{mol} \cdot \mathrm{kg}^{-1} \cdot \mathrm{min}^{-1}\right)$. After resting in a supine position for $120 \mathrm{~min}$, a second arterialized blood sample was drawn and a muscle biopsy was collected from the vastus lateralis muscle ( $\mathrm{t}=0 \mathrm{~min}$ ). Subjects then received a single bolus $(250 \mathrm{~mL})$ of test drink containing $20 \mathrm{~g}$ intrinsically L-[1- $\left.{ }^{13} \mathrm{C}\right]$ phenylalanine-labeled WHEY, CAS, or CASH. Arterialized blood samples were collected at $\mathrm{t}=15,30,45,60,75,90,105,120,150,180,210,240,270,300,330$ and $360 \mathrm{~min}$, with a second muscle biopsy taken from the same incision at $\mathrm{t}=180 \mathrm{~min}$ and a third muscle biopsy taken from the vastus lateralis of the contralateral limb at $\mathrm{t}=360 \mathrm{~min}$. The biopsies from the same incision were taken in a distal and proximal direction, respectively. Blood samples were collected in EDTA containing tubes and centrifuged at $1000 \mathrm{~g}$ for $5 \mathrm{~min}$ at $4^{\circ} \mathrm{C}$. Aliquots of plasma were frozen in liquid nitrogen and stored at $-80^{\circ} \mathrm{C}$. Muscle biopsies were obtained from the middle region of the vastus lateralis, $15 \mathrm{~cm}$ above the patella and approximately $3 \mathrm{~cm}$ below entry through the fascia, using the percutaneous needle biopsy technique (27). Muscle samples were dissected carefully and freed from any visible non- 
muscle material. The muscle samples were immediately frozen in liquid nitrogen and stored at $-80^{\circ} \mathrm{C}$ until further analysis.

Table 2. Amino acid composition of the proteins

\begin{tabular}{|c|c|c|c|}
\hline & WHEY & CAS & $\mathrm{CASH}$ \\
\hline Alanine, $\mathrm{g}$ & 1.0 & 0.6 & 0.6 \\
\hline Arginine, $\mathrm{g}$ & 0.5 & 0.7 & 0.7 \\
\hline Aspartic acid, g & 2.3 & 1.3 & 1.3 \\
\hline Cysteine, $\mathrm{g}$ & 0.7 & 0.1 & 0.1 \\
\hline Glutamic acid, g & 3.2 & 4.1 & 4.1 \\
\hline Glycine, g & 0.4 & 0.3 & 0.3 \\
\hline Histidine, g & 0.4 & 0.5 & 0.5 \\
\hline Isoleucine, g & 1.2 & 1.1 & 1.1 \\
\hline Leucine, g & 2.5 & 1.7 & 1.7 \\
\hline Lysine, g & 2.1 & 1.4 & 1.4 \\
\hline Methionine, g & 0.4 & 0.5 & 0.5 \\
\hline Phenylalanine, g & 0.7 & 0.9 & 0.9 \\
\hline Proline, g & 0.7 & 2.1 & 2.1 \\
\hline Serine, $\mathrm{g}$ & 0.7 & 1.3 & 1.3 \\
\hline Threonine, g & 0.9 & 0.8 & 0.8 \\
\hline Tryptophan, g & 0.5 & 0.2 & 0.2 \\
\hline Tyrosine, $\mathrm{g}$ & 0.8 & 1.1 & 1.1 \\
\hline Valine, $\mathrm{g}$ & 1.0 & 1.3 & 1.3 \\
\hline Total AA, g & 20.0 & 20.0 & 20.0 \\
\hline Total NEAA, g & 10.7 & 12.1 & 12.1 \\
\hline Total EAA, g & 9.3 & 7.9 & 7.9 \\
\hline
\end{tabular}

Amount in g per 20 gram protein. $W H E Y=$ whey; $C A S=$ casein; $C A S H=$ casein hydrolysate; $A A=$ amino acids; $E A A=$ essential $A A ; N E A A=$ non-EAA.

\section{Preparation of intrinsically labeled protein and beverage composition}

Intrinsically L- $\left[1-{ }^{13} \mathrm{C}\right]$ phenylalanine-labeled milk protein was obtained by infusing a Holstein cow with large quantities of L- $\left[1-{ }^{13} \mathrm{C}\right]$ phenylalanine, collecting milk, and purifying the casein and whey fractions as described previously (23). Part of the casein fraction was enzymatically hydrolyzed by specific endopeptidases and proline-specific endoprotease by DSM Food Specialties (Delft, Netherlands). The L$\left[1-{ }^{13} \mathrm{C}\right]$ phenylalanine enrichments in WHEY, CAS, and CASH, assessed by gas chromatography-mass spectrometry after hydrolysis, were 24.6, 29.4, and 29.4 mole percent excess (MPE), respectively. The proteins met all chemical and bacteriologic specifications for human consumption. Subjects received a beverage volume of 250 $\mathrm{mL}$ to ensure a given dose of $20 \mathrm{~g}$ WHEY, CAS, or CASH (Table 2). The protein drinks provided 1.1, 1.7, and $1.7 \mathrm{mmol} \mathrm{L}-\left[1-{ }^{13} \mathrm{C}\right]$ phenylalanine in WHEY, CAS, and CASH, respectively. Drinks were uniformly flavored by adding $5 \mathrm{~mL}$ vanilla flavor (Givaudan, Naarden, The Netherlands) per L beverage. 


\section{Plasma analyses}

Plasma glucose (Uni Kit III, 07367204, Roche, Basel, Switzerland) concentrations were analyzed with the COBAS-FARA semi-automatic analyzer (Roche). Insulin was analyzed by radio-immunoassay (Insulin RIA kit, LINCO Research Inc., St. Charles, MO, USA). Plasma (100 $\mu \mathrm{L})$ for amino acid analyses was deproteinized on ice with $10 \mathrm{mg}$ dry 5-sulphosalicylic acid, mixed and the clear supernatant was collected after centrifugation. Plasma amino acid concentrations were determined by HPLC, after precolumn derivatization with o-phthaldialdehyde (28). For plasma phenylalanine enrichment measurements, plasma phenylalanine was derivatized to its $t$ butyldimethyl-silyl (TBDMS) derivative and its ${ }^{13} \mathrm{C}$ and ${ }^{2} \mathrm{H}$ enrichments were determined by electron impact ionization gas chromatography-mass spectrometry (GCMS, Agilent 6890N GC/5973N MSD Little Falls, DE, USA) using selected ion monitoring of masses 336, 337 and 341 for unlabeled and labeled $\left(1-{ }^{13} \mathrm{C}\right.$ and ring $\left.^{2}{ }^{2} \mathrm{H}_{5}\right)$ phenylalanine, respectively (29). We applied standard regression curves in all isotopic enrichment analyses to assess linearity of the mass spectrometer and to control for the loss of tracer. Enrichments were corrected for the presence of both the ${ }^{13} \mathrm{C}$ and ${ }^{2} \mathrm{H}_{5}$ phenylalanine isotopes (30).

\section{Muscle analyses}

For measurement of $\mathrm{L}-\left[1-{ }^{13} \mathrm{C}\right]$ phenylalanine enrichment in the tissue-free amino acid pool and mixed muscle protein, $55 \mathrm{mg}$ of wet muscle was freeze-dried. Collagen, blood, and other non-muscle fiber material were removed from the muscle fibers under a light microscope. The isolated muscle fiber mass (10-15 mg) was weighed and 8 volumes ( $8 x$ dry weight of isolated muscle fibers $x$ wet/dry ratio) icecold $2 \%$ perchloric acid (PCA) were added. The tissue was then homogenized and centrifuged. The supernatant was collected and processed in the same manner as the plasma samples, such that tissue-free $\mathrm{L}-\left[1-{ }^{13} \mathrm{C}\right]$ phenylalanine enrichment could be measured using its TBDMS derivative on a GC-MS.

The protein pellet was washed with 3 additional $1.5 \mathrm{~mL}$ washes of $2 \%$ PCA, dried and hydrolyzed in $6 \mathrm{M} \mathrm{HCl}$ at $120^{\circ} \mathrm{C}$ for $15-18 \mathrm{~h}$. The hydrolyzed protein fraction was dried under a nitrogen stream while heated to $120^{\circ} \mathrm{C}$, then $50 \%$ acetic acid solution was added, and the hydrolyzed protein was passed over a Dowex exchange resin (AG 50W-X8, 100-200 mesh hydrogen form, Biorad, Hercules, CA, USA) using 2M $\mathrm{NH}_{4} \mathrm{OH}$. The eluate was collected in a vial for the measurement of L-[1${ }^{13} \mathrm{C}$ ]phenylalanine enrichment in mixed muscle protein as described previously (17). In short, L-[1- $\left.{ }^{13} \mathrm{C}\right]$ phenylalanine was derivatized to its $\mathrm{N}(\mathrm{O}, \mathrm{S})$-ethoxycarbonyl ethyl esters (31). Thereafter, the ratios labeled/unlabeled derivatives were determined by GC-C-IRMS (Finnigan MAT 252, Bremen, Germany). Standard regression curves were applied to assess linearity of the mass spectrometer and to control for the loss of tracer. The coefficient of variance (CV) for the measurement of L-[1${ }^{13} \mathrm{C}$ ]phenylalanine enrichment in mixed muscle protein averaged $1.1 \pm 0.1 \%$. 


\section{Calculations}

Ingestion of L-[1- $\left.{ }^{13} \mathrm{C}\right]$ phenylalanine-labeled protein, intravenous infusion of L-[ring${ }^{2} \mathrm{H}_{5}$ ]phenylalanine, and arterialized blood sampling were used to assess whole-body amino acid kinetics in non-steady state conditions. Total, exogenous, and endogenous rate of appearance $\left(R_{a}\right)$ and plasma availability of dietary phenylalanine (i.e., fraction of dietary phenylalanine that appeared in the systemic circulation, Phe $\left.e_{\text {plasma }}\right)$ were calculated using modified Steele's equations $(12,22)$. These parameters were calculated as follows:

$$
\begin{aligned}
& \text { Total } R_{a}=\frac{F-p V \cdot C(t) \cdot \mathrm{d} E_{i v} / \mathrm{d} t}{E_{i v}(t)} \\
& \text { Exo } R_{a}=\frac{\text { Total } \mathrm{R}_{\mathrm{a}} \cdot E_{p o}(t)+p V \cdot \mathrm{d} E_{p o} / \mathrm{d} t}{E_{p r o t}} \\
& \text { Endo } R_{a}=\text { Total } \mathrm{R}_{\mathrm{a}}-\text { Exo } \mathrm{R}_{\mathrm{a}}-\mathrm{F} \\
& \text { Phe } e_{\text {plasma }}=\left(\frac{\mathrm{AUC}_{\text {ExoRa }}}{\text { Phe }_{\text {Prot }}}\right) \cdot B W \cdot 100
\end{aligned}
$$

where $F$ is the intravenous tracer infusion rate $\left(\mu \mathrm{mol} \cdot \mathrm{kg}^{-1} \cdot \mathrm{min}^{-1}\right), \mathrm{pV}(0.125)$ is the distribution volume for phenylalanine (22). $C(t)$ is the mean plasma phenylalanine concentration between two time points. $d E_{i v} / d t$ represents the time-dependent variations of plasma phenylalanine enrichment derived from the intravenous tracer and $E_{i v}(t)$ is the mean plasma phenylalanine enrichment from the intravenous tracer between two consecutive time points. Exo $R_{a}$ represents the plasma entry rate of dietary phenylalanine, $E_{p o}(t)$ is the mean plasma phenylalanine enrichment for the oral tracer, $d E_{p o} / d t$ represents the time-dependent variations of plasma phenylalanine enrichment derived from the oral tracer and $E_{\text {prot }}$ is the L-[1${ }^{13} \mathrm{C}$ ]phenylalanine enrichment in the dietary protein. Phe $e_{\text {Prot }}$ is the amount of dietary phenylalanine ingested, $A \cup C_{\text {ExoRa }}$ represents the area under the curve (AUC) of Exo $R_{a}$, which corresponds to the amount of dietary phenylalanine that appeared in the blood over a $6 \mathrm{~h}$ period following drink ingestion. BW represents the subjects' body weight in $\mathrm{kg}$.

Total phenylalanine rate of disappearance (Total $R_{d}$ ) equals the rate of phenylalanine hydroxylation (first step in phenylalanine oxidation) and utilization for protein synthesis. This parameter is calculated as follows: 


$$
\operatorname{Total} R_{d}=\operatorname{Total} R_{a}-p V \cdot \frac{\mathrm{d} C}{\mathrm{~d} t}
$$

The FSR of mixed muscle protein synthesis was calculated by dividing the increment in enrichment in the product, i.e. mixed muscle protein-bound L-[1${ }^{13} \mathrm{C}$ ]phenylalanine, by the enrichment of the precursor. Muscle tissue-free L-[1${ }^{13} \mathrm{C}$ ]phenylalanine enrichments during the decay of enrichment levels were used as precursor to provide an estimate for the fractional synthesis rates of mixed muscle proteins during non-steady state conditions (32). Muscle FSR's were calculated as follows:

$$
F S R=\frac{E_{B}(t)-E_{B}(0)}{\int_{t_{0}}^{t_{1}} E_{F}(t) \cdot d t}
$$

where $E_{B}(t)-E_{B}(0)$ is the delta increment of mixed muscle protein-bound L-[1${ }^{13} \mathrm{C}$ ]phenylalanine during the $6 \mathrm{~h}$ incorporation period and $E_{F}$ is the mean muscle tissue-free $\mathrm{L}-\left[1-{ }^{13} \mathrm{C}\right]$ phenylalanine enrichment obtained from muscle biopsies at 3 and $6 \mathrm{~h}$.

\section{Statistics}

All data are expressed as mean \pm SEM. A two-way repeated measures ANOVA with time and treatment as factors was used to compare differences between treatments over time in older subjects. In case of a significant interaction between time and treatment, a Bonferroni post-hoc test was applied to locate these differences. For non-time dependent variables, a one-way ANOVA with treatment as factor was used to compare differences between treatments in older subjects. Statistical significance was set at $\mathrm{P}<0.05$. All calculations were performed using the SPSS 15.0.1.1 software package. 


\section{Results}

\section{Plasma analyses}

Plasma insulin concentrations showed a rapid, but short-lived, increase following protein ingestion in all groups (Figure 1). Peak plasma insulin concentrations were higher following WHEY and CASH ingestion when compared with CAS $(P<0.05)$. Plasma glucose concentrations did not change significantly following protein ingestion and averaged $5.3 \pm 0.1,5.3 \pm 0.1$, and $5.2 \pm 0.1 \mathrm{mmol} \cdot \mathrm{L}^{-1}$, respectively.

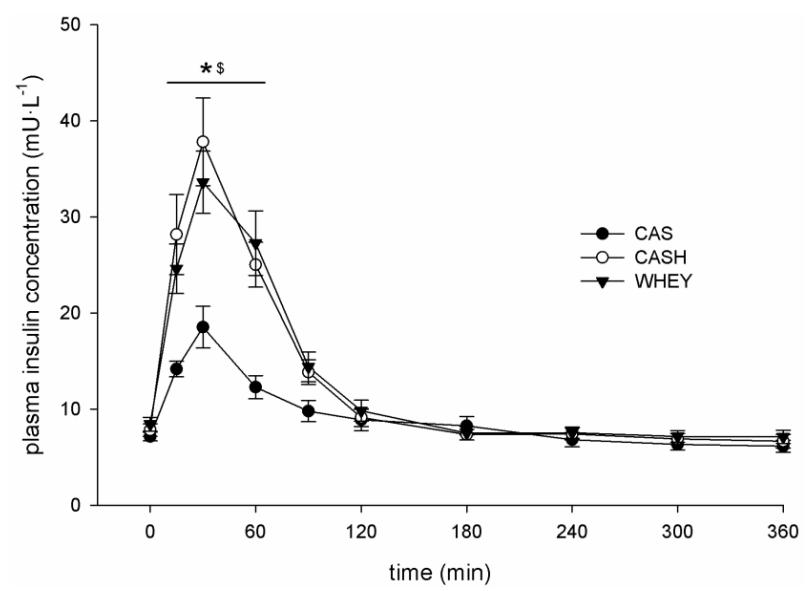

Figure 1. Plasma insulin concentrations $\left(m U \cdot \mathrm{L}^{-1}\right)$ following ingestion of CAS $(n=16)$, CASH $(n=16)$, and WHEY $(n=16)$. Values represent means \pm SEM. Data were analyzed with repeated measures ANOVA (time $x$ treatment). In case of a significant interaction, a Bonferroni post-hoc test was applied to locate these differences. time effect, $\mathrm{P}<0.001$; treatment effect, $\mathrm{P}<0.01$; time $\mathrm{x}$ treatment interaction, $\mathrm{P}<0.001$. *WHEY significantly different from CAS, $\mathrm{P}<0.05$; ${ }^{\$} \mathrm{CASH}$ significantly different from CAS, $\mathrm{P}<0.05$.

Plasma phenylalanine $(A)$, leucine $(B)$, and total essential amino acid (EAA; C) concentrations over time are illustrated in Figure 2. Following dietary protein ingestion, a rapid increase in plasma EAA concentrations was observed in all groups, with higher peak amino acid concentrations following WHEY and CASH compared with CAS ingestion $(P<0.05)$. Peak plasma phenylalanine and leucine concentrations were significantly higher following CASH compared with CAS ingestion $(P<0.05)$. In addition, peak plasma leucine concentrations were higher following WHEY compared with CASH ingestion $(P<0.01)$.

The time courses of plasma L-[1- $\left.{ }^{13} \mathrm{C}\right]$ phenylalanine and $\mathrm{L}-\left[\right.$ ring- $\left.{ }^{2} \mathrm{H}_{5}\right]$-phenylalanine enrichments are illustrated in Figure 3. Plasma L- $\left[1-{ }^{13} \mathrm{C}\right]$-phenylalanine enrichment (ingested tracer) increased after ingestion of the test drink with higher peak values observed following ingestion of CASH compared with WHEY and CAS $(P<0.01)$. However, plasma L- $\left[1-{ }^{13} \mathrm{C}\right]$-phenylalanine enrichments were higher in CAS vs CASH and WHEY during the later stages of the experimental period $(P<0.01)$. The plasma 
L-[ring- ${ }^{2} \mathrm{H}_{5}$ ]phenylalanine enrichment (infused tracer) decreased during all treatments after dietary protein ingestion, with lowest values observed during the early stages after $\mathrm{CASH}$ ingestion $(\mathrm{P}<0.05)$. Following the initial decrease, plasma L-[ring${ }^{2} \mathrm{H}_{5}$ ]phenylalanine enrichments increased over time, with higher values observed following WHEY and CASH compared with CAS ingestion $(P<0.05)$.
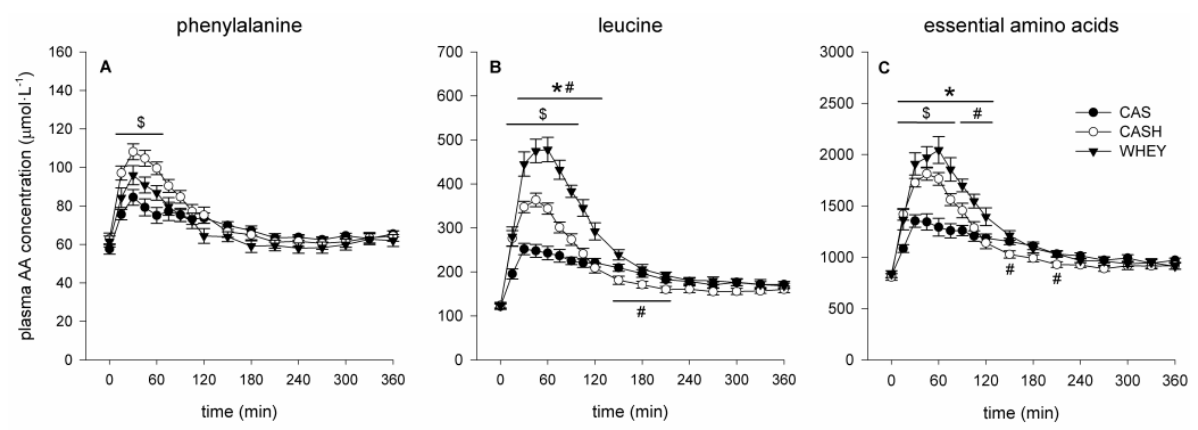

Figure 2. Plasma phenylalanine (A), leucine (B), and essential amino acids (C) concentrations $\left(\mu \mathrm{mol} \cdot \mathrm{L}^{-1}\right)$ following ingestion of CAS $(n=16)$, CASH $(n=16)$, and WHEY $(n=16)$. Values represent means \pm SEM. Data were analyzed with repeated measures ANOVA (time $x$ treatment). In case of a significant interaction, a Bonferroni post-hoc test was applied to locate these differences. Plasma phenylalanine concentration: time effect, $\mathrm{P}<0.001$; treatment effect, $\mathrm{P}=0.12$; time $\mathrm{x}$ treatment interaction, $\mathrm{P}<0.05$. Plasma leucine concentration: time effect, $\mathrm{P}<0.001$; treatment effect, $\mathrm{P}<0.001$; time $\mathrm{x}$ treatment interaction, $\mathrm{P}<0.001$. Plasma EAA concentration: time effect, $\mathrm{P}<0.001$; treatment effect, $\mathrm{P}<0.001$; time $\mathrm{x}$ treatment interaction, $\mathrm{P}<0.001$. *WHEY significantly different from CAS, $\mathrm{P}<0.05 ;{ }^{\$} \mathrm{CASH}$ significantly different from CAS, $\mathrm{P}<0.05$; "WHEY significantly different from $\mathrm{CASH}, \mathrm{P}<0.05$.

\section{Whole-body phenylalanine kinetics}

Whole-body phenylalanine kinetics are presented in Figure 4. Ingestion of the intrinsically labeled dietary protein resulted in a rapid rise in exogenous phenylalanine appearance rates (Figure 4A), with higher peak values observed following WHEY and CASH when compared with CAS ingestion $(P<0.05)$. In contrast, during the later stages of the postprandial period exogenous phenylalanine appearance rates were higher following CAS compared with WHEY and CASH ingestion $(P<0.01)$. Total exogenous phenylalanine appearance (expressed as AUC over $6 \mathrm{~h}$ ) was expressed as a fraction of the total amount of phenylalanine that was ingested (Equation 4). The fraction of dietary phenylalanine that appeared in the systemic circulation during the $6 \mathrm{~h}$ postprandial period was higher following WHEY $(58 \pm 1 \%)$ when compared with CAS $(53 \pm 1 \% ; \mathrm{P}<0.01)$ and CASH $(55 \pm 1 \% ; \mathrm{P}<0.05)$ ingestion. However, no differences were observed between WHEY and CASH ingestion during the first few hours (0-2 h) after protein ingestion ( $41 \pm 1$ and $39 \pm 1 \%$, respectively). Ingestion of WHEY and CASH resulted in a much higher plasma availability of dietary phenylalanine when compared with CAS $(25 \pm 1 \%$; $\mathrm{P}<0.001)$ during this early postprandial phase $(0-2 \mathrm{~h})$. 
Endogenous phenylalanine appearance rates rapidly decreased following protein ingestion, with lower values observed following ingestion of WHEY compared with CAS ( $t=75-150$ min; Figure 4B; $P<0.05)$. Total phenylalanine appearance and disappearance rates (Figures $4 C$ and $4 D$ ) were higher during the initial stages after ingesting $C A S H$ vs CAS $(P<0.05)$, whereas rates were higher during the later stages following CAS vs WHEY and CASH ingestion $(P<0.05)$.

\section{$\mathrm{L}-\left[1-{ }^{13} \mathrm{C}\right]$ phenylalanine}

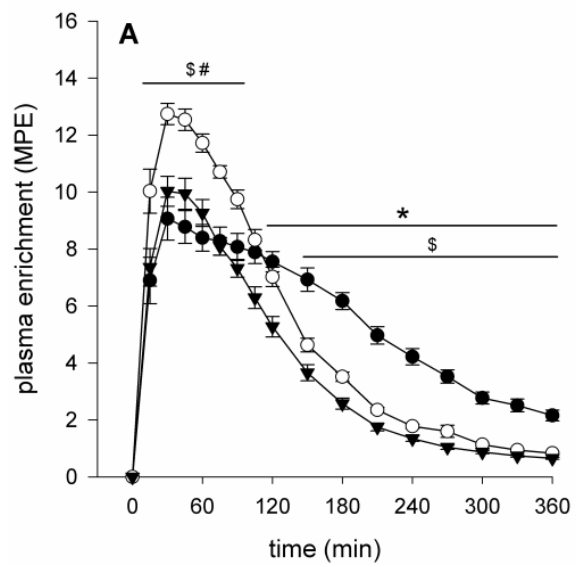

L-[ring- ${ }^{2} \mathrm{H}_{5}$ ]phenylalanine

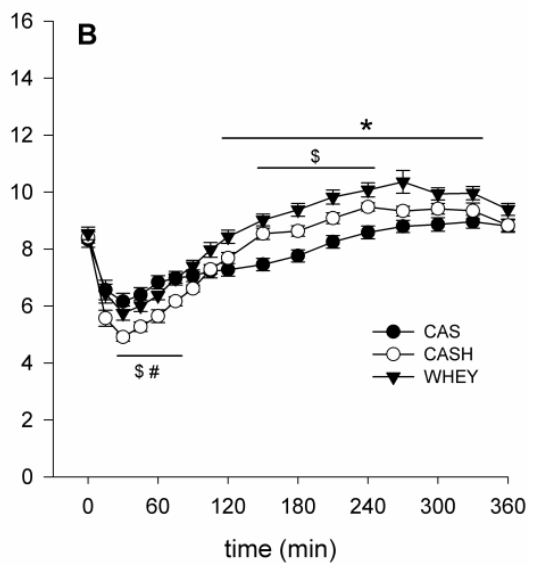

Figure 3. Plasma L-[1 $\left[{ }^{13} \mathrm{C}\right]$ phenylalanine (A) and L-[ring- $\left.{ }^{2} \mathrm{H}_{5}\right]$ phenylalanine (B) enrichment expressed as mole percent excess (MPE) following ingestion of CAS $(n=16)$, CASH $(n=16)$, and WHEY $(n=16)$. Values represent means \pm SEM. Data were analyzed with repeated measures ANOVA (time $x$ treatment). In case of a significant interaction, a Bonferroni post-hoc test was applied to locate these differences. Plasma L$\left[1{ }^{13} \mathrm{C}\right]$ phenylalanine enrichment: time effect, $\mathrm{P}<0.001$; treatment effect, $\mathrm{P}<0.001$; time $\mathrm{x}$ treatment interaction, $\mathrm{P}<0.001$. Plasma L-[ring- $\left.{ }^{2} \mathrm{H}_{5}\right]$-phenylalanine enrichment: time effect, $\mathrm{P}<0.001$; treatment effect, $\mathrm{P}<0.01$; time $x$ treatment interaction, $\mathrm{P}<0.001$. ${ }^{*}$ WHEY significantly different from $C A S, P<0.05$; ${ }^{\$}$ CASH significantly different from CAS, $P<0.05$; ${ }^{*}$ WHEY significantly different from $C A S H, P<0.05$.

\section{Muscle tracer analysis}

Tissue-free $\mathrm{L}-\left[1-{ }^{13} \mathrm{C}\right]$ phenylalanine enrichments (MPE), determined in muscle samples collected at 0,3 , and $6 \mathrm{~h}$ following protein ingestion were $0.11 \pm 0.03$, $2.59 \pm 0.17$, and $0.61 \pm 0.05$ for WHEY; $0.15 \pm 0.07,4.97 \pm 0.36$, and $1.64 \pm 0.13$ for CAS; and $0.13 \pm 0.08,3.78 \pm 0.25$, and $0.84 \pm 0.08$ for CASH. Tissue-free enrichments changed significantly over time $(\mathrm{P}<0.001)$ and differed between treatments $(P<0.001)$.

Protein-bound L-[1- $\left.{ }^{13} \mathrm{C}\right]$ phenylalanine enrichments at 3 and $6 \mathrm{~h}$ into the postprandial period were $0.010 \pm 0.001$ and $0.017 \pm 0.002$ MPE following WHEY ingestion; $0.012 \pm 0.001$ and $0.019 \pm 0.002$ MPE following CAS inges-tion; and $0.012 \pm 0.001$ and $0.017 \pm 0.002 \mathrm{MPE}$ following CASH ingestion. Protein-bound phenylalanine enrichments increased over time $(P<0.001)$ and did not differ between treatments. 
exogenous PHE Ra

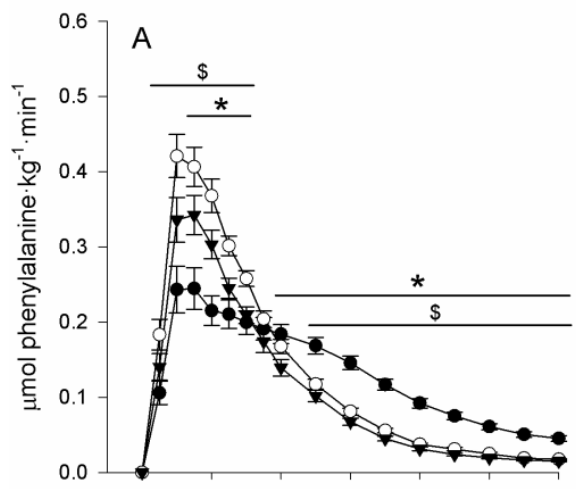

total PHE Ra

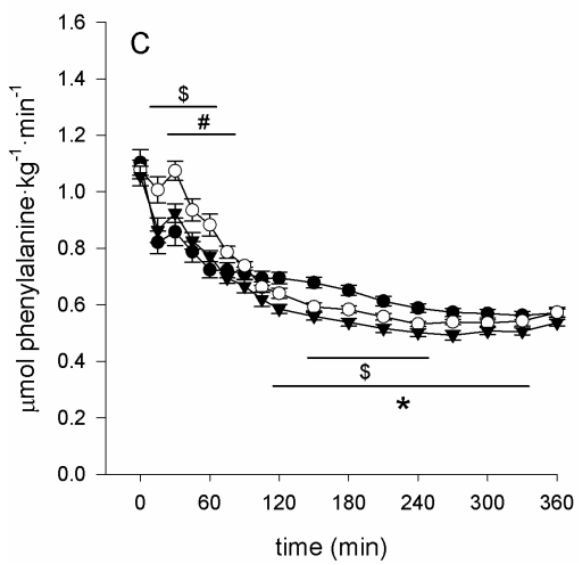

endogenous PHE Ra

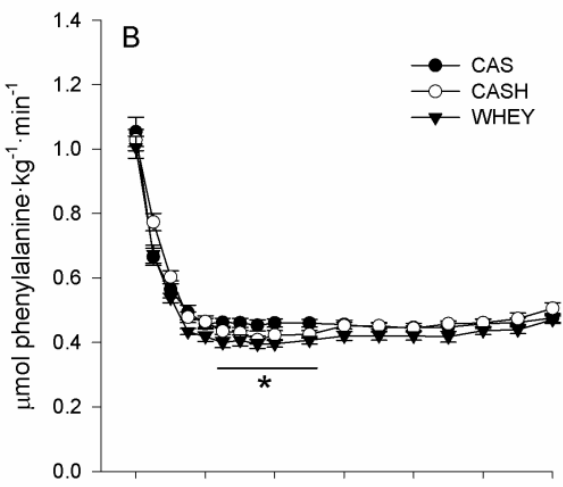

total PHE Rd

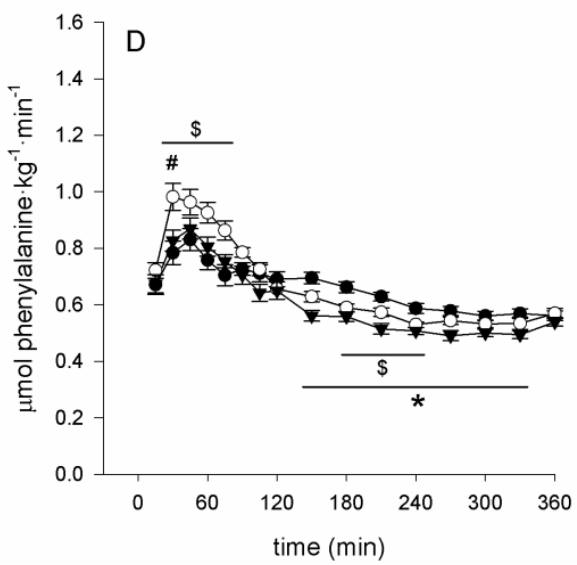

Figure 4. Whole-body phenylalanine (PHE) kinetics expressed per kg body-weight. (A) exogenous PHE rate of appearance $\left(R_{a}\right)$, (B) endogenous PHE $R_{a},(C)$ total PHE $R_{a}$, and (D) total PHE rate of disappearance $\left(R_{d}\right)$ in $\mu \mathrm{mol} \cdot \mathrm{kg}^{-1} \cdot \mathrm{min}^{-1}$ following ingestion of CAS $(n=16)$, CASH $(n=16)$, and WHEY $(n=16)$. Values represent means \pm SEM. Data were analyzed with repeated measures ANOVA (time $x$ treatment). In case of a significant interaction, a Bonferroni post-hoc test was applied to locate these differences. Exogenous PHE $R_{a}$ : time effect, $P<0.001$; treatment effect, $P<0.001$; time $x$ treatment interaction, $P<0.001$. Endogenous $P H E R_{a}$ : time effect, $P<0.001$; treatment effect, $P=0.07$; time $x$ treatment interaction, $P<0.05$. Total $P H E R_{a}$ : time effect, $P<0.001$; treatment effect, $P=0.30$; time $x$ treatment interaction, $P<0.001$. Total $P H E$ $R_{d}$ : time effect, $P<0.001$; treatment effect, $P=0.26$; time $x$ treatment interaction, $P<0.001$. ${ }^{*}$ WHEY significantly different from CAS, $\mathrm{P}<0.05$; ${ }^{\$} \mathrm{CASH}$ significantly different from $\mathrm{CAS}, \mathrm{P}<0.05$; ${ }^{*}$ WHEY significantly different from $\mathrm{CASH}, \mathrm{P}<0.05$.

\section{Mixed muscle protein synthesis rates}

Mixed muscle protein synthesis rates, expressed as fractional synthetic rates (FSR) with tissue-free $\mathrm{L}-\left[1-{ }^{13} \mathrm{C}\right]$ phenylalanine enrichment as precursor, are presented in Figure 5. FSR values assessed following WHEY ingestion $\left(0.15 \pm 0.02 \% \cdot h^{-1}\right)$ were higher compared with both CAS $\left(0.08 \pm 0.01 \% \cdot h^{-1} ; \mathrm{P}<0.01\right)$ and CASH $(0.10 \pm 0.01$ 
$\% \cdot h-1 ; \mathrm{P}<0.05)$. When plasma L- $\left[1-{ }^{13} \mathrm{C}\right]$ phenylalanine enrichment was used as precursor, calculated FSR values were lower, but revealed a similar intervention effect (data not shown).

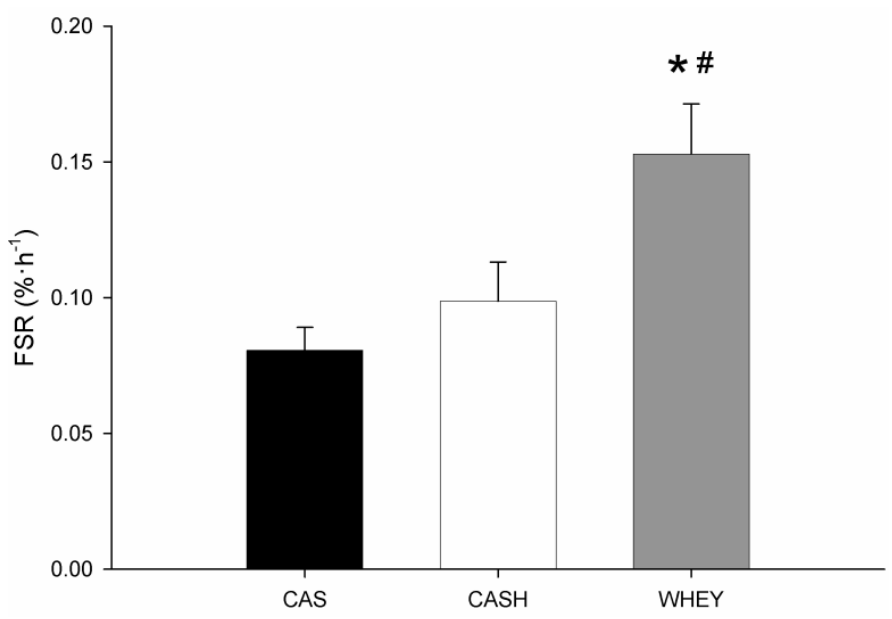

Figure 5. Fractional mixed muscle protein synthetic rates (FSR), with tissue-free $L-\left[1-{ }^{13} \mathrm{C}\right]$ phenylalanine enrichments as precursor, following ingestion of CAS $(n=16)$, CASH $(n=16)$, and WHEY $(n=16)$. Values represent means \pm SEM. Data were analyzed with ANOVA with Bonferroni correction. *WHEY significantly different from CAS, $\mathrm{P}<0.01$; ${ }^{\mathrm{W}}$ WHEY significantly different from $\mathrm{CASH}, \mathrm{P}<0.05$.

\section{Correlations}

Postprandial FSR values showed a significant positive correlation with the delta $(\Delta)$ peak increase in plasma EAA concentrations $(r=0.55: P<0.01)$. The postprandial rise in plasma leucine concentrations showed the strongest correlation with postprandial FSR values $(r=0.66 ; P<0.01)$. However, significant correlations were also observed for the rise in plasma isoleucine $(r=0.60 ; P<0.01)$, tryptophan $(r=0.45$; $P<0.01)$, threonine $(r=0.44 ; P<0.01)$, lysine $(r=0.43 ; P<0.01)$, and valine $(r=0.39$; $P<0.05)$ concentrations, whereas the rise in phenylalanine $(r=0.26 ; P=0.10)$ and methionine $(r=0.20 ; P=0.21)$ concentrations did not show a significant correlation. Correlations between postprandial FSR values and the $\Delta$ peak increase in plasma EAA (A) and leucine (B) concentrations are illustrated in Figure 6.

\section{Discussion}

In the present study, we compared dietary protein digestion and absorption kinetics and subsequent muscle protein accretion following the ingestion of $20 \mathrm{~g}$ whey (WHEY), casein (CAS), and casein hydrolysate (CASH) in healthy, older men. Intrinsically $\mathrm{L}-\left[1-{ }^{13} \mathrm{C}\right]$ phenylalanine-labeled milk proteins were ingested, in combination with continuous intravenous infusion of L-[ring- $\left.{ }^{2} \mathrm{H}_{5}\right]$ phenylalanine, to allow insight 
into the metabolic fate of dietary protein-derived amino acids following protein ingestion. Protein-derived phenylalanine appeared more rapidly in the circulation following WHEY and CASH when compared with CAS ingestion. WHEY protein ingestion resulted in greater mixed muscle protein fractional synthetic rates (FSR) when compared with CAS and CASH administration. Postprandial FSR values correlated strongly with the rise in plasma leucine concentration.
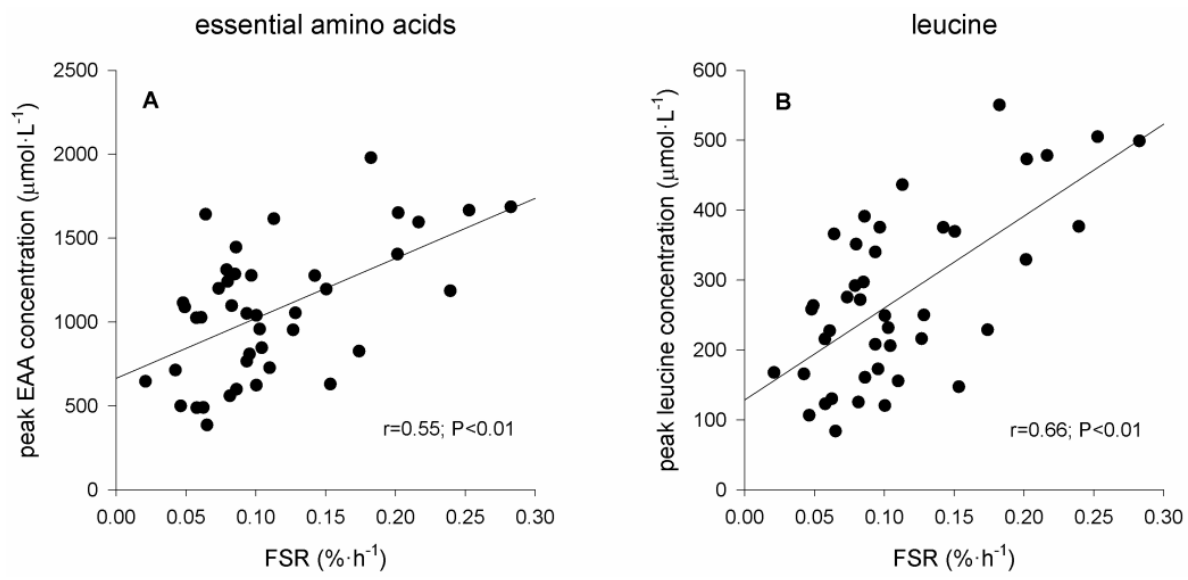

Figure 6. Correlations between postprandial FSR values and delta $(\Delta)$ peak plasma EAA $(A)$ and leucine (B) concentrations: EAA $(r=0.55 ; P<0.01)$ and leucine $(r=0.66 ; P<0.01)$. Data were analyzed with twotailed tests of significance using Pearson's correlation coefficients $(n=48)$.

In older adults, ingestion of whey protein has been suggested to effectively increase postprandial protein retention when compared with casein ingestion (11, 12). Much of this effect can be attributed to apparent differences in digestion and absorption kinetics between these proteins $(13,14)$. Following ingestion of whey and casein protein we observed a more rapid rise in plasma phenylalanine, leucine, as well as total essential amino acid concentrations in WHEY vs CAS (Figure 2). In addition, a more rapid rise in plasma $\mathrm{L}-\left[1-{ }^{13} \mathrm{C}\right]$ phenylalanine enrichment was observed following WHEY compared with CAS ingestion (Figure 3). In agreement, whole-body tracer kinetics showed a much greater appearance rate of proteinderived phenylalanine in the circulation during the first $2 \mathrm{~h}$ after WHEY vS CAS ingestion (Figure 4A). These findings are in line with previous work that identified whey as a fast and casein as a slow digestible protein $(13,14)$.

Besides differences in digestion and absorption kinetics, whey and casein also differ markedly in their amino acid composition (Table 2). Consequently, the proposed greater anabolic properties of whey versus casein could be attributed to differences in digestion and absorption kinetics as well as differences in amino acid composition between these proteins. In trying to define the characteristics responsible for the proposed greater anabolic properties of whey versus casein admin- 
istration, we hydrolysed part of the intrinsically labeled casein to obtain a casein hydrolysate. The latter provided us with an important tool to investigate the impact of differences in amino acid composition and digestion and absorption kinetics on postprandial muscle protein synthesis, because a casein hydrolysate shows similar digestion and absorption kinetics when compared with a whey protein $(13,17)$ while retaining its unique amino acid composition (Table 2). In accordance, we observed similar dietary protein-derived phenylalanine appearance rates following ingestion of WHEY and CASH (Figure 4A). Furthermore, the amount of dietary phenylalanine that appeared in the circulation directly following protein intake (0-2 h) did not differ between WHEY and CASH ingestion and was higher when compared with CAS. However, plasma dietary phenylalanine availability over the total 6

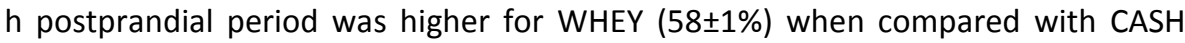
$(55 \pm 1 \%$; $P<0.05)$ and CAS $(53 \pm 1 \% ; P<0.01)$ ingestion. The latter implies that more dietary amino acids became available following WHEY compared with CASH and CAS ingestion.

In the postprandial phase, a rapid increase in plasma essential amino acid (EAA) concentrations was observed in all groups, with peak EAA concentrations reaching higher plasma levels following WHEY and CASH compared with CAS ingestion (Figure $2 \mathrm{C}$ ). Specific differences in plasma EAA concentrations following protein ingestion were observed when looking at individual EAA. In particular peak plasma leucine concentrations differed significantly between treatments, with the highest and lowest peak concentrations observed following WHEY and CAS ingestion, respectively (Figure $2 \mathrm{~B}$ ). As the dietary amino acid rate of appearance from the gut was greater following CASH compared with CAS ingestion (Figure 4A), it is evident that the greater rise in plasma leucine concentration following CASH administration (Figure $2 \mathrm{~B}$ ) is entirely attributed to its accelerated digestion and absorption kinetics. However, despite similar protein digestion and absorption kinetics following WHEY and CASH ingestion, a greater rise in plasma leucine concentration was observed following WHEY compared with CASH. The latter is largely attributed to the greater leucine content of WHEY (12.5\%) versus CASH (8.5\%). This difference might be of substantial relevance, as the postprandial rise in plasma leucine concentration has been proposed to be responsible for the increase in mixed muscle protein synthetic rate (18-21).

To study the postprandial muscle protein synthetic response to the ingestion of the different proteins sources, mixed muscle protein fractional synthetic rates (FSR) were calculated based on the ingested $\mathrm{L}-\left[1-{ }^{13} \mathrm{C}\right]$ phenylalanine tracer. This allowed us to compare the capacity of the different protein sources to stimulate de novo postprandial muscle protein accretion. Mixed muscle protein FSR values assessed following WHEY ingestion were higher when compared with CAS $(P<0.01)$ and CASH $(P<0.05$; Figure 5$)$. These FSR values clearly demonstrate that WHEY ingestion 
stimulates postprandial muscle protein accretion more effectively than do CAS and CASH in older men.

In this study, we report significant correlations between the postprandial rise ( $\Delta$ peak) in plasma EAA concentrations and FSR values (Figure 6A). The postprandial rise in plasma leucine concentrations showed the strongest positive correlation $(r=0.66 ; P<0.01)$ with postprandial FSR values (Figure $6 B$ ). This seems to be in line with the suggestion that leucine forms a key-factor regulating postprandial muscle protein synthesis (18-21). We speculate that the postprandial rise in plasma EAA concentration, with leucine in particular, defines the subsequent postprandial rate of muscle protein synthesis. In the present study, we observed a greater rise in plasma leucine concentration following WHEY versus CAS and CASH ingestion. This difference was attributed to faster digestion and absorption kinetics as well as a higher leucine content of the protein and also resulted in peak plasma leucine concentrations that were considerably higher following WHEY when compared with CAS and CASH ingestion $\left(526 \pm 21,282 \pm 13\right.$, and $381 \pm 14 \mu \mathrm{mol} \cdot \mathrm{L}^{-1}$, respectively). The present study is the first to compare in vivo dietary protein digestion and absorption kinetics and subsequent postprandial muscle protein accretion following the ingestion of a meal-like amount of whey, intact casein, and hydrolysed casein in healthy, older men. Whey protein is more effective than casein and casein hydrolysate in promoting postprandial muscle protein accretion in healthy, older men. The greater muscle protein synthetic response to whey ingestion is likely attributed to both its faster digestion and absorption kinetics and higher leucine content, thereby further increasing the postprandial rise in plasma leucine concentration. These data are of great clinical relevance to define more effective nutritional strategies to attenuate the age-related loss of muscle mass.

\section{Acknowledgements}

We gratefully acknowledge the assistance of Patrick Dubbelman and Antoine Zorenc in performing the experiments, Zouhair Ariss for skilfull technical assistance, and the enthusiastic support of the subjects who volunteered to participate in these experiments.

BP and LJCVL designed the study. BP organized and carried out the clinical experiments with the assistance of JMGS. JMGS and APG performed the stable isotope analyses. BP performed the (statistical) analysis of the data and wrote the manuscript together with LJCVL and YB. HK provided medical assistance. None of the authors had a personal or financial conflict of interest. 


\section{References}

1. Cruz-Jentoft AJ, Baeyens JP, Bauer JM, et al. Sarcopenia: European consensus on definition and diagnosis: Report of the European Working Group on Sarcopenia in Older People. Age Ageing 2010;39:412-23.

2. Cuthbertson $D$, Smith $K$, Babraj J, et al. Anabolic signaling deficits underlie amino acid resistance of wasting, aging muscle. FASEB J 2005;19:422-4.

3. Guillet $C$, Prod'homme M, Balage $M$, et al. Impaired anabolic response of muscle protein synthesis is associated with S6K1 dysregulation in elderly humans. FASEB J 2004;18:1586-7.

4. Volpi E, Mittendorfer B, Rasmussen BB, Wolfe RR. The response of muscle protein anabolism to combined hyperaminoacidemia and glucose-induced hyperinsulinemia is impaired in the elderly. $J$ Clin Endocrinol Metab 2000;85:4481-90.

5. Mosoni L, Valluy MC, Serrurier B, et al. Altered response of protein synthesis to nutritional state and endurance training in old rats. Am J Physiol 1995;268:E328-35.

6. Volpi E, Kobayashi H, Sheffield-Moore M, Mittendorfer B, Wolfe RR. Essential amino acids are primarily responsible for the amino acid stimulation of muscle protein anabolism in healthy elderly adults. Am J Clin Nutr 2003;78:250-8.

7. Volpi E, Mittendorfer B, Wolf SE, Wolfe RR. Oral amino acids stimulate muscle protein anabolism in the elderly despite higher first-pass splanchnic extraction. Am J Physiol 1999;277:E513-20.

8. Koopman $\mathrm{R}$, Walrand $\mathrm{S}$, Beelen $\mathrm{M}$, et al. Dietary protein digestion and absorption rates and the subsequent postprandial muscle protein synthetic response do not differ between young and elderly men. J Nutr 2009;139:1707-13.

9. Symons TB, Schutzler SE, Cocke TL, Chinkes DL, Wolfe RR, Paddon-Jones D. Aging does not impair the anabolic response to a protein-rich meal. Am J Clin Nutr 2007;86:451-6.

10. Tang JE, Phillips SM. Maximizing muscle protein anabolism: the role of protein quality. Curr Opin Clin Nutr Metab Care 2009;12:66-71.

11. Dangin $M$, Boirie $Y$, Guillet $C$, Beaufrere B. Influence of the protein digestion rate on protein turnover in young and elderly subjects. J Nutr 2002;132:3228S-33S.

12. Dangin M, Guillet C, Garcia-Rodenas $C$, et al. The rate of protein digestion affects protein gain differently during aging in humans. J Physiol 2003;549:635-44.

13. Boirie $\mathrm{Y}$, Dangin M, Gachon P, Vasson MP, Maubois JL, Beaufrere B. Slow and fast dietary proteins differently modulate postprandial protein accretion. Proc Natl Acad Sci U S A 1997;94:14930-5.

14. Dangin M, Boirie $Y$, Garcia-Rodenas $C$, et al. The digestion rate of protein is an independent regulating factor of postprandial protein retention. Am J Physiol Endocrinol Metab 2001;280:E340-8.

15. Bohe J, Low A, Wolfe RR, Rennie MJ. Human muscle protein synthesis is modulated by extracellular, not intramuscular amino acid availability: a dose-response study. J Physiol 2003;552:315-24.

16. Tang JE, Moore DR, Kujbida GW, Tarnopolsky MA, Phillips SM. Ingestion of whey hydrolysate, casein, or soy protein isolate: effects on mixed muscle protein synthesis at rest and following resistance exercise in young men. J Appl Physiol 2009;107:987-92.

17. Koopman R, Crombach N, Gijsen AP, et al. Ingestion of a protein hydrolysate is accompanied by an accelerated in vivo digestion and absorption rate when compared with its intact protein. Am J Clin Nutr 2009;90:106-15.

18. Buse MG, Reid SS. Leucine. A possible regulator of protein turnover in muscle. J Clin Invest 1975;56:1250-61.

19. Katsanos CS, Kobayashi H, Sheffield-Moore M, Aarsland A, Wolfe RR. A high proportion of leucine is required for optimal stimulation of the rate of muscle protein synthesis by essential amino acids in the elderly. Am J Physiol Endocrinol Metab 2006;291:E381-7.

20. Rieu I, Balage $M$, Sornet $C$, et al. Leucine supplementation improves muscle protein synthesis in elderly men independently of hyperaminoacidaemia. J Physiol 2006;575:305-15.

21. Leenders $M$, van Loon LC. Leucine as a pharmaconutrient to prevent and/or treat sarcopenia and type 2 diabetes. Nutr Rev. 2011 Nov;69(11):675-89. 
22. Boirie Y, Gachon P, Corny S, Fauquant J, Maubois JL, Beaufrere B. Acute postprandial changes in leucine metabolism as assessed with an intrinsically labeled milk protein. Am J Physiol 1996;271:E1083-91.

23. van Loon $\mathrm{L}$, Boirie $\mathrm{Y}$, Gijsen AP, et al. The production of intrinsically labeled milk protein provides a functional tool for human nutrition research. J Dairy Sci 2009;92:4812-22.

24. ADA. Standards of medical care in diabetes--2010. Diabetes Care 2010;33 Suppl 1:S11-61.

25. Alberti KG, Zimmet PZ. Definition, diagnosis and classification of diabetes mellitus and its complications. Part 1: diagnosis and classification of diabetes mellitus provisional report of a WHO consultation. Diabet Med 1998;15:539-53.

26. Abumrad NN, Rabin D, Diamond MP, Lacy WW. Use of a heated superficial hand vein as an alternative site for the measurement of amino acid concentrations and for the study of glucose and alanine kinetics in man. Metabolism 1981;30:936-40.

27. Bergstrom J. Percutaneous needle biopsy of skeletal muscle in physiological and clinical research. Scand J Clin Lab Invest 1975;35:609-16.

28. van Eijk HM, Rooyakkers DR, Deutz NE. Rapid routine determination of amino acids in plasma by high-performance liquid chromatography with a 2-3 microns Spherisorb ODS II column. J Chromatogr 1993;620:143-8.

29. Wolfe RR. Radioactive and stable isotope tracers in biomedicine: principles and practice of kinetic analysis. New York: Wiley-Liss 1992.

30. Biolo $G$, Tessari $P$, Inchiostro $S$, et al. Leucine and phenylalanine kinetics during mixed meal ingestion: a multiple tracer approach. Am J Physiol 1992;262:E455-63.

31. Husek P. Amino acid derivatization and analysis in five minutes. FEBS Lett 1991;280:354-6.

32. Zhang XJ, Chinkes DL, Wolfe RR. Measurement of muscle protein fractional synthesis and breakdown rates from a pulse tracer injection. Am J Physiol Endocrinol Metab 2002;283:E753-64. 



\section{Chapter 4}

\section{Amino acid absorption and subsequent muscle protein accretion following graded intakes of whey protein in elderly men}

American Journal of Physiology - Endocrinology and Metabolism 2012 Apr 15;302(8):E992-9 


\section{Abstract}

Whey protein ingestion has been shown to effectively stimulate postprandial muscle protein accretion in older adults. However, the impact of the amount of whey protein ingested on protein digestion and absorption kinetics, whole-body protein balance, and postprandial muscle protein accretion remains to be established. We aimed to fill this gap by including 33 healthy, older men $(73 \pm 2 \mathrm{y})$ which were randomly assigned to ingest 10,20 , or $35 \mathrm{~g}$ of intrinsically L-[1${ }^{13} \mathrm{C}$ ]phenylalanine-labeled whey protein; $\mathrm{n}=11$ per treatment. Ingestion of labeled whey protein was combined with continuous intravenous L-[ring- ${ }^{2} \mathrm{H}_{5}$ ]phenylalanine and $\mathrm{L}$-[ring- ${ }^{2} \mathrm{H}_{2}$ ]tyrosine infusion to assess the metabolic fate of whey proteinderived amino acids. Dietary protein digestion and absorption rapidly increased following ingestion of 10, 20, and $35 \mathrm{~g}$ whey protein, with the lowest and highest (peak) values observed following 10 and $35 \mathrm{~g}$, respectively $(P<0.05)$. Whole-body net protein balance was positive in all groups $\left(19 \pm 1,37 \pm 2\right.$, and $\left.58 \pm 2 \mu \mathrm{mol} \cdot \mathrm{kg}^{-1}\right)$, with the lowest and highest values observed following ingestion of 10 and $35 \mathrm{~g}$, respectively $(\mathrm{P}<0.05)$. Postprandial muscle protein accretion, assessed by L-[1${ }^{13} \mathrm{C}$ ]phenylalanine incorporation in muscle protein, was higher following ingestion of $35 \mathrm{~g}$ when compared with $10(\mathrm{P}<0.01)$ or $20 \mathrm{~g}(\mathrm{P}<0.05)$. We conclude that ingestion of $35 \mathrm{~g}$ whey protein results in greater amino acid absorption and subsequent stimulation of de novo muscle protein synthesis when compared with the ingestion of 10 or $20 \mathrm{~g}$ whey protein in healthy, older men. 


\section{Introduction}

Aging is accompanied by a progressive decline in skeletal muscle mass, termed sarcopenia (1). Data have been obtained to suggest that the skeletal muscle protein synthetic response to food intake is impaired in older adults $(2,3)$. This proposed anabolic resistance is now regarded a key-factor in the etiology of sarcopenia. Consequently, we as well as other labs have been trying to define effective interventional strategies to compensate for this anabolic resistance by improving postprandial muscle protein accretion in older adults (4-7). Recently, we assessed the impact of protein digestion and absorption kinetics as well as amino acid composition on postprandial muscle protein synthesis rates in older men. The results showed that whey protein was more effective than either casein or casein hydrolysate protein in stimulating postprandial muscle protein accretion (8).

Besides the quality of dietary protein, i.e. its amino acid composition and digestion and absorption kinetics, also the amount of dietary protein ingested likely modulates postprandial muscle protein synthesis rates $(5,8)$. So far, no study has assessed the impact of ingesting different amounts of whey protein on protein digestion and absorption kinetics, whole-body protein balance, and postprandial muscle protein synthesis rates in older adults. As the metabolic fate of amino acids ingested as dietary protein cannot be assessed by oral or intravenous administration of labeled free amino acids $(9,10)$, we specifically produced intrinsically labeled whey protein by infusing cows with large quantities of $\mathrm{L}-\left[1-{ }^{13} \mathrm{C}\right]$ phenylalanine, collecting milk, and purifying the whey protein fraction (11). The use of intrinsically labeled whey protein allowed us to assess the impact of ingesting different amounts of whey protein on in vivo protein digestion and absorption kinetics and subsequent muscle protein accretion without the need for extensive assumptions and extrapolations.

In the present study, 33 elderly men ingested a single bolus of 10, 20, or $35 \mathrm{~g}$ intrinsically $\mathrm{L}-\left[1-{ }^{13} \mathrm{C}\right]$ phenylalanine-labeled whey protein. Ingestion of labeled whey protein was combined with continuous intravenous L-[ring- ${ }^{2} \mathrm{H}_{5}$ ]phenylalanine and L-[ring- ${ }^{2} \mathrm{H}_{2}$ ]tyrosine infusion, during which blood and muscle tissue samples were collected. This study is the first to describe the impact of the amount of whey protein ingested on subsequent protein digestion and absorption kinetics, splanchnic sequestration, whole-body protein metabolism, and postprandial muscle protein accretion in vivo in older males.

\section{Methods}

\section{Subjects}

Thirty-three healthy, older men ( $73 \pm 2$ y) participated in this study. Subjects were randomly assigned to ingest a single bolus of 10,20 , or $35 \mathrm{~g}$ intrinsically L-[1- 
$\left.{ }^{13} \mathrm{C}\right]$ phenylalanine-labeled whey protein; $\mathrm{n}=11$ per treatment. Subjects' characteristics are presented in Table 1. None of the subjects had a history of participating in any regular exercise program. All subjects were informed on the nature and possible risk of the experimental procedures before their written informed consent was obtained. This study was approved by the Medical Ethics Committee of the Academic Hospital Maastricht.

Table 1. Subjects' characteristics

\begin{tabular}{lccc}
\hline & $\begin{array}{c}10 \mathrm{~g} \\
\text { whey protein } \\
(\mathrm{n}=11)\end{array}$ & $\begin{array}{c}20 \mathrm{~g} \\
\text { whey protein } \\
(\mathrm{n}=11)\end{array}$ & $\begin{array}{c}35 \mathrm{~g} \\
\text { whey protein } \\
(\mathrm{n}=11)\end{array}$ \\
\hline Age $(\mathrm{y})$ & $73 \pm 2$ & $73 \pm 2$ & $73 \pm 1$ \\
Weight $(\mathrm{kg})$ & $77.2 \pm 1.6$ & $78.0 \pm 1.7$ & $77.2 \pm 1.3$ \\
BMI $\left(\mathrm{kg} \cdot \mathrm{m}^{-2}\right)$ & $25.2 \pm 0.5$ & $25.6 \pm 0.5$ & $25.4 \pm 0.6$ \\
Fat \% & $21.1 \pm 0.9$ & $21.1 \pm 1.0$ & $20.8 \pm 1.3$ \\
Lean body mass $(\mathrm{kg})$ & $60.9 \pm 1.3$ & $61.4 \pm 1.0$ & $61.1 \pm 1.2$ \\
HbA1c $(\%)$ & $5.7 \pm 0.1$ & $5.9 \pm 0.1$ & $5.6 \pm 0.1$ \\
Basal glucose $\left(\mathrm{mmol} \cdot \mathrm{L}^{-1}\right)$ & $5.5 \pm 0.1$ & $5.6 \pm 0.1$ & $5.5 \pm 0.1$ \\
Basal insulin $\left(\mathrm{mU} \cdot \mathrm{L}^{-1}\right)$ & $17.1 \pm 1.6$ & $19.1 \pm 2.8$ & $16.3 \pm 1.1$ \\
\hline
\end{tabular}

Values are expressed as means \pm SEM. Data were analyzed with ANOVA. No differences were observed between groups.

\section{Pretesting}

Before selection in the study, an oral glucose tolerance test (OGTT) was performed to assess glucose tolerance and screen for type 2 diabetes prevalence according to World Health Organization criteria (12). Prior to the OGTT, body weight and height were assessed and body composition was determined by DXA (Discovery A, Hologic Corporate, Bedford, MA, USA).

\section{Diet and activity prior to testing}

All subjects consumed a standardized meal $\left(32 \pm 2 \mathrm{~kJ} \cdot \mathrm{kg}^{-1}\right.$ body weight, providing 55 $\mathrm{E} \%$ carbohydrate, $15 \mathrm{E} \%$ protein and $30 \mathrm{E} \%$ fat) the evening prior to the experiment. All volunteers were instructed to refrain from any sort of exhaustive physical activity and to keep their diet as constant as possible $3 \mathrm{~d}$ before the experiments.

\section{Protocol}

At 8.00 am, following an overnight fast, subjects arrived at the laboratory by car or public transportation. A Teflon catheter was inserted into an antecubital vein for stable isotope infusion. A second Teflon catheter was inserted in a heated dorsal hand vein of the contralateral arm and placed in a hot-box $\left(60^{\circ} \mathrm{C}\right)$ for arterialized blood sampling (13). Following basal blood collection ( $t=-240 \mathrm{~min}$ ), the plasma 
phenylalanine and tyrosine pools were primed with a single intravenous dose L[ring- ${ }^{2} \mathrm{H}_{5}$ ]phenylalanine $\left(2 \mu \mathrm{mol} \cdot \mathrm{kg}^{-1}\right)$ and $\mathrm{L}-\left[\operatorname{ring}_{-}{ }^{2} \mathrm{H}_{2}\right.$ ]tyrosine $\left(0.775 \mu \mathrm{mol} \cdot \mathrm{kg}^{-1}\right)$, after which continuous L-[ring- $\left.{ }^{2} \mathrm{H}_{5}\right]$-phenylalanine and $\mathrm{L}$-[ring- $\left.{ }^{2} \mathrm{H}_{2}\right]$ tyrosine infusion was started $\left(0.050 \pm 0.001\right.$ and $0.019 \pm 0.001 \mu \mathrm{mol} \cdot \mathrm{kg}^{-1} \cdot \mathrm{min}^{-1}$, respectively). After resting in a supine position for $120 \mathrm{~min}$, a second arterialized blood sample was drawn and the first muscle biopsy was collected from the vastus lateralis muscle $(t=-120 \mathrm{~min})$, marking the start of a fasted, baseline period. During this period, additional blood samples were drawn every $30 \mathrm{~min}$ and a second muscle biopsy was taken at $\mathrm{t}=0 \mathrm{~min}$. Directly following the second biopsy, subjects ingested $\mathrm{a}$ single bolus of 10,20 , or $35 \mathrm{~g}$ intrinsically L-[1- $\left.{ }^{13} \mathrm{C}\right]$ phenylalanine-labeled whey protein dissolved in $400 \mathrm{~mL}$ water, which was uniformly flavored by adding $5 \mathrm{~mL}$ vanilla flavor (Givaudan, Naarden, The Netherlands) per Liter beverage. Arterialized blood samples were collected at $\mathrm{t}=15,30,45,60,90,120,180$, and $240 \mathrm{~min}$ with a third muscle biopsy taken from the contralateral limb at $\mathrm{t}=240 \mathrm{~min}$. Blood samples were collected in EDTA containing tubes and centrifuged at $1000 \mathrm{~g}$ for $5 \mathrm{~min}$ at $4^{\circ} \mathrm{C}$. Aliquots of plasma were frozen in liquid nitrogen and stored at $-80^{\circ} \mathrm{C}$. Muscle biopsies were obtained from the middle region of the vastus lateralis. Biopsies from the same incision were taken in a distal and proximal direction, respectively. Muscle samples were dissected carefully and freed from any visible non-muscle material. The muscle samples were immediately frozen in liquid nitrogen and stored at $-80^{\circ} \mathrm{C}$ until further analysis.

\section{Preparation of intrinsically labeled whey protein}

Intrinsically L-[1- $\left.{ }^{13} \mathrm{C}\right]$ phenylalanine-labeled whey protein was obtained by infusing a Holstein cow with large quantities of L-[1- $\left.{ }^{13} \mathrm{C}\right]$ phenylalanine, collecting milk, and purifying the whey protein fraction as described previously (11). The whey protein fraction consisted of $93 \%$ native whey protein and $7 \%$ casein and denatured whey protein and did not provide other sources of nutrients, i.e. during processing, milk fat and lactose were removed to $\sim 1 \%$ of original milk content. The L-[1${ }^{13} \mathrm{C}$ ]phenylalanine enrichment of labeled whey protein, which was assessed by gas chromatography-mass spectrometry after hydrolysis, was 31.3 mole percent excess (MPE). The labeled protein met all chemical and bacteriologic specifications for human consumption.

\section{Plasma analyses}

Plasma glucose (Uni Kit III, 07367204, Roche, Basel, Switzerland) concentrations were analyzed with the COBAS-FARA semi-automatic analyzer (Roche). Insulin was analyzed by radio-immunoassay (Insulin RIA kit, LINCO Research Inc., St. Charles, MO, USA). Plasma (100 $\mu \mathrm{L}$ ) for amino acid analyses was deproteinized on ice with $10 \mathrm{mg}$ dry 5-sulphosalicylic acid, mixed and the clear supernatant was collected after centrifugation. Plasma amino acid concentrations were determined by HPLC, 
after precolumn derivatization with o-phthaldialdehyde (14). For plasma phenylalanine and tyrosine enrichment measurements, plasma phenylalanine and tyrosine were derivatized to their t-butyldimethylsilyl (TBDMS) derivatives and their ${ }^{13} \mathrm{C}$ and ${ }^{2} \mathrm{H}$ enrichments were determined by electron ionization GC-MS (Agilent 6890N GC/5973N MSD Little Falls, DE, USA) using selected ion monitoring of masses 336, 337 and 341 for unlabeled and labeled $\left(1-{ }^{13} \mathrm{C}\right.$ and ring- $\left.{ }^{2} \mathrm{H}_{5}\right)$ phenylalanine, respectively; and masses $466,467,468$ and 470 for unlabeled and labeled $\left(1-{ }^{13} \mathrm{C}\right.$, ring- ${ }^{2} \mathrm{H}_{2}$ and ring $-{ }^{2} \mathrm{H}_{4}$ ) tyrosine, respectively (15). Standard regression curves were applied in all isotopic enrichment analysis to assess linearity of the mass spectrometer and to control for the loss of tracer. Phenylalanine and tyrosine enrichments were corrected for the presence of both the ${ }^{13} \mathrm{C}$ and ${ }^{2} \mathrm{H}$ isotopes (16).

\section{Muscle tissue analyses}

For measurement of L- $\left[1-{ }^{13} \mathrm{C}\right]$ phenylalanine and L-[ring $\left.-{ }^{2} \mathrm{H}_{5}\right]$ phenylalanine enrichment in mixed muscle protein, $55 \mathrm{mg}$ of wet muscle was freeze-dried. Collagen, blood, and other non-muscle fiber material were removed from the muscle fibers under a light microscope. The isolated muscle fiber mass $(10-15 \mathrm{mg})$ was weighed and 8 volumes ( $8 x$ dry weight of isolated muscle fibers $x$ wet/dry ratio) ice-cold $2 \%$ perchloric acid (PCA) were added. The tissue was then homogenized and centrifuged. The protein pellet was washed with 3 additional $1.5 \mathrm{~mL}$ washes of $2 \%$ PCA, dried and hydrolyzed in $6 \mathrm{M} \mathrm{HCl}$ at $120^{\circ} \mathrm{C}$ for $15-18 \mathrm{~h}$. The hydrolyzed protein fraction was dried under a nitrogen stream while heated to $120^{\circ} \mathrm{C}$, then $50 \%$ acetic acid solution was added and the hydrolyzed protein was passed over a Dowex exchange resin (AG 50W-X8, 100-200 mesh hydrogen form, Biorad, Hercules, CA, USA) using $2 \mathrm{M} \mathrm{NH}_{4} \mathrm{OH}$. The eluate was divided over 2 vials for separate measurement of both $\mathrm{L}-\left[1-{ }^{13} \mathrm{C}\right]$ phenylalanine and L-[ring- $\left.{ }^{2} \mathrm{H}_{5}\right]$ phenylalanine enrichment in mixed muscle protein as described previously (5). In short, L- $\left[1-{ }^{13} \mathrm{C}\right]$ phenylalanine and L-[ring${ }^{2} \mathrm{H}_{5}$ ] phenylalanine were derivatized to their $\mathrm{N}(\mathrm{O}, \mathrm{S})$-ethoxycarbonyl ethyl esters and MTBSTFA-phenylethylamines, respectively (17). Thereafter, the ratios labeled/unlabeled derivatives were determined by GC-C-IRMS (Finnigan MAT 252, Bremen, Germany) and GC-MS, respectively. Standard regression curves were applied to assess linearity of the mass spectrometer and to control for loss of tracer.

\section{Calculations}

Ingestion of L-[1- $\left.{ }^{13} \mathrm{C}\right]$ phenylalanine-labeled protein, intravenous infusion of L-[ring${ }^{2} \mathrm{H}_{5}$ ]phenylalanine and L-[ring- ${ }^{2} \mathrm{H}_{2}$ ]tyrosine, and arterialized blood sampling were used to assess whole-body protein metabolism in non-steady state conditions. Total, exogenous, and endogenous phenylalanine rate of appearance $\left(R_{a}\right)$ and plasma availability of dietary phenylalanine (i.e., fraction of dietary phenylalanine 
that appeared in the systemic circulation, $P$ Phe plasma $_{\text {) }}$ were calculated using modified Steele's equations $(9,18)$. These parameters were calculated as follows:

$$
\begin{aligned}
& \text { Total } R_{a}=\frac{F-p V \cdot C(t) \cdot \mathrm{d} E_{i v} / \mathrm{d} t}{E_{i v}(t)} \\
& \text { Exo } R_{a}=\frac{\text { Total }_{\mathrm{a}} \cdot E_{p o}(t)+p V \cdot \mathrm{d} E_{p o} / \mathrm{d} t}{E_{p r o t}} \\
& \text { Endo } R_{a}=\text { Total } \mathrm{R}_{\mathrm{a}}-\text { Exo } \mathrm{R}_{\mathrm{a}}-\mathrm{F} \\
& \text { Phe } e_{\text {plasma }}=\left(\frac{\mathrm{AUC}_{\text {ExoRa }}}{\operatorname{Phe}_{\text {Prot }}}\right) \cdot B W \cdot 100
\end{aligned}
$$

where $F$ is the intravenous tracer infusion rate $\left(\mu \mathrm{mol} \cdot \mathrm{kg}^{-1} \cdot \mathrm{min}^{-1}\right), p V(0.125)$ is the distribution volume for phenylalanine (9). $C(t)$ is the mean plasma phenylalanine concentration between two time points. $d E_{i v} / d t$ represents the time-dependent variations of plasma phenylalanine enrichment derived from the intravenous tracer and $E_{i v}(t)$ is the mean plasma phenylalanine enrichment from the intravenous tracer between two consecutive time points. Exo $R_{a}$ represents the plasma entry rate of dietary phenylalanine, $E_{p o}(t)$ is the mean plasma phenylalanine enrichment for the oral tracer, $d E_{p o} / d t$ represents the time-dependent variations of plasma phenylalanine enrichment derived from the oral tracer and $E_{\text {prot }}$ is the L-[1${ }^{13} \mathrm{C}$ ]phenylalanine enrichment in the dietary protein. Phe $e_{\text {Prot }}$ is the amount of dietary phenylalanine ingested, $A \cup C_{\text {ExoRa }}$ represents the area under the curve (AUC) of Exo $R_{a}$, which corresponds to the amount of dietary phenylalanine that appeared in the blood over the $4 \mathrm{~h}$ period following drink intake. BW represents the subjects' body weight in $\mathrm{kg}$.

Total rate of disappearance of phenylalanine (Total $R_{d}$ ) equals the rate of phenylalanine (PHE) to tyrosine (TYR) conversion by hydroxylation (first step in phenylalanine oxidation) and utilization for protein synthesis. These parameters can be calculated as follows:

$$
\begin{aligned}
& \text { Total } R_{d}=\text { Total } R_{a}-p V \cdot \frac{\mathrm{d} C}{\mathrm{~d} t} \\
& \text { PHE to TYR conversion }=\operatorname{Tyr} R_{a} \cdot \frac{E_{t}(t)}{E_{p}(t)} \cdot \frac{\operatorname{Phe} R_{d}}{\left(F_{p}+\operatorname{Phe} R_{d}\right)}
\end{aligned}
$$


where Phe $R_{d}$ and Tyr $R_{a}$ are the flux rates for phenylalanine and tyrosine, respectively, $E_{t}(t)$ and $E_{p}(t)$ are the mean plasma enrichments of L-[ring- ${ }^{2} \mathrm{H}_{4}$ ]tyrosine and L[ring- ${ }^{2} \mathrm{H}_{5}$ ]phenylalanine, respectively, and $F_{p}$ is the infusion rate of the phenylalanine tracer.

The fractional rate of mixed muscle protein synthesis (FSR) was calculated in $\% \cdot \mathrm{h}^{-1}$ by the precursor-product method (15):

$$
F S R=\frac{\Delta E_{p}}{E_{\text {precursor }} \cdot t} \cdot 100
$$

where $\Delta E_{p}$ is the delta increment of muscle protein-bound L-[ring${ }^{2} \mathrm{H}_{5}$ ]phenylalanine during the incorporation period. $E_{\text {precursor }}$ is the average plasma L[ring- ${ }^{2} \mathrm{H}_{5}$ ]phenylalanine enrichment during the time period for determination of amino acid incorporation. $t$ indicates the time interval $(h)$ between biopsies.

\section{Statistics}

All data are expressed as means \pm SEM. A two-way repeated measures ANOVA with time and treatment as factors was used to compare differences between treatments over time. In case of a significant interaction between time and treatment, a Bonferroni post-hoc test was applied to locate these differences. For non-time dependent variables, one-way ANOVA with treatment as factor was used to compare differences between treatments. Statistical significance was set at $P<0.05$. All calculations were performed using the SPSS 15.0.1.1 software package.

\section{Results}

\section{Plasma analyses}

Plasma insulin concentrations showed a rapid, but short-lived, increase following whey protein ingestion in all groups (Figure 1A). Peak plasma insulin concentrations were higher following ingestion of $35 \mathrm{~g}$ when compared with 10 and $20 \mathrm{~g}$ whey protein $(P<0.05)$. Plasma glucose concentrations did not change over time or between treatments and averaged $5.2 \pm 0.1,5.1 \pm 0.1$, and $5.1 \pm 0.1 \mathrm{mmol} \cdot \mathrm{L}^{-1}$ in the 10 , 20, and 35 g experiment, respectively (Figure 1B). 

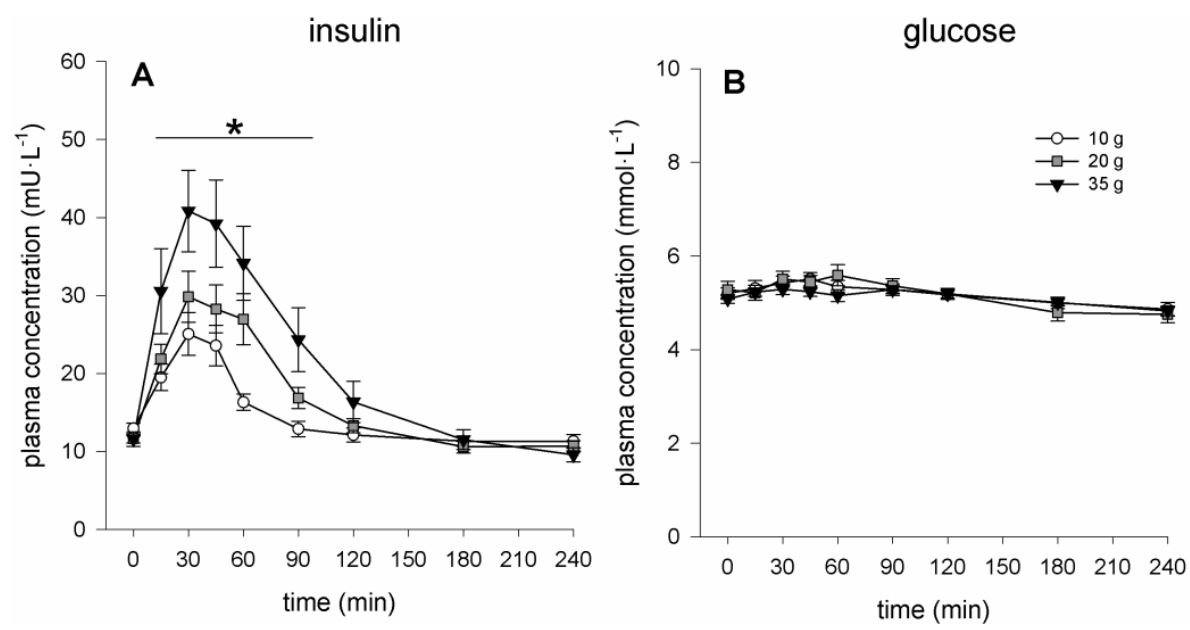

Figure 1. Plasma insulin $\left(A ; m U \cdot \mathrm{L}^{-1}\right)$ and glucose $\left(B ; \mathrm{mmol} \cdot \mathrm{L}^{-1}\right)$ concentrations following ingestion of 10 $(n=11), 20(n=11)$, and $35 \mathrm{~g}(\mathrm{n}=11)$ whey protein. Values represent means \pm SEM. Data were analyzed with repeated measures ANOVA (time $x$ treatment). In case of a significant interaction, a Bonferroni post-hoc test was applied to locate these differences. Time effect, $\mathrm{P}<0.001$; treatment effect, $\mathrm{P}<0.05$; time $\mathrm{x}$ treatment interaction, $\mathrm{P}<0.01$. *35 g significantly higher when compared with $10 \mathrm{~g}, \mathrm{P}<0.05$.

Plasma phenylalanine, leucine, and essential amino acid (EAA) concentrations over time are illustrated in Figure $\mathbf{2}$.
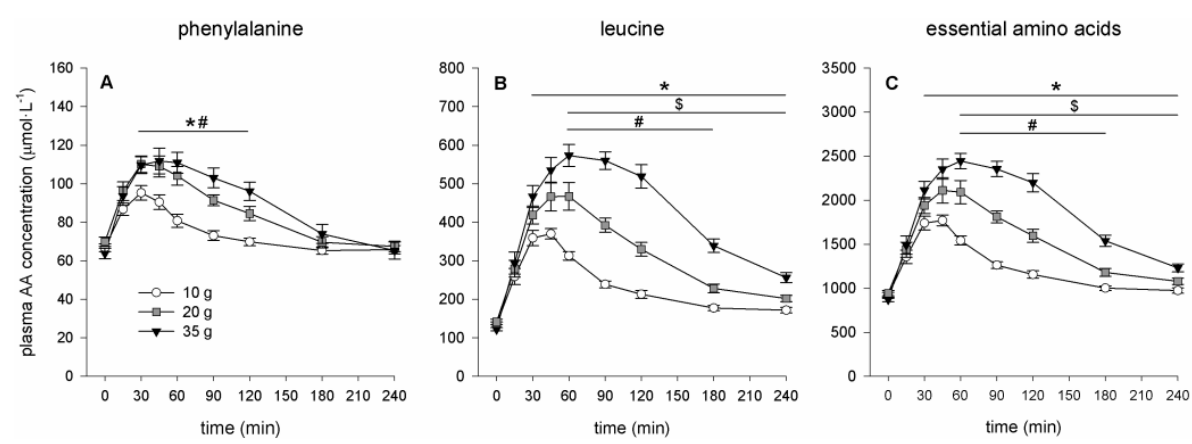

Figure 2. Plasma phenylalanine $(A)$, leucine $(B)$, and essential amino acid (EAA; $C$ ), concentrations $\left(\mu \mathrm{mol} \cdot \mathrm{L}^{-1}\right)$ following ingestion of $10(n=11), 20(n=11)$, and $35 \mathrm{~g}(\mathrm{n}=11)$ whey protein. Values represent means \pm SEM. Data were analyzed with repeated measures ANOVA (time $x$ treatment). In case of a significant interaction, a Bonferroni post-hoc test was applied to locate these differences. Plasma EAA concentrations: time effect, $\mathrm{P}<0.001$; treatment effect, $\mathrm{P}<0.001$; time $\mathrm{x}$ treatment interaction, $\mathrm{P}<0.001$. Plasma phenylalanine concentrations: time effect, $\mathrm{P}<0.001$; treatment effect, $\mathrm{P}<0.01$; time $\mathrm{x}$ treatment interaction, $P<0.001$. Plasma leucine concentrations: time effect, $P<0.001$; treatment effect, $P<0.001$; time $\mathrm{x}$ treatment interaction, $\mathrm{P}<0.001$. ${ }^{*} 35 \mathrm{~g}$ significantly different when compared with $10 \mathrm{~g}, \mathrm{P}<0.05$; $\$ 35$ g significantly different when compared with $20 \mathrm{~g}, \mathrm{P}<0.05 ;{ }^{*} 20 \mathrm{~g}$ significantly different when compared with $10 \mathrm{~g}, \mathrm{P}<0.05$. 
Following whey protein ingestion, a rapid increase in plasma EAA concentrations was observed in all groups, with the lowest and highest concentrations following ingestion of 10 and $35 \mathrm{~g}$ whey protein, respectively $(\mathrm{P}<0.01)$. Plasma phenylalanine concentrations were significantly higher following ingestion of 20 and $35 \mathrm{~g} \mathrm{com-}$ pared with the ingestion of $10 \mathrm{~g}$ whey protein $(P<0.05)$. The lowest and highest (peak) plasma leucine concentrations were observed in the 10 and $35 \mathrm{~g}$ experiment, respectively $(P<0.01)$.

The time course of plasma L-[1- $\left.-{ }^{13} \mathrm{C}\right]$ phenylalanine and L-[ring- $\left.{ }^{2} \mathrm{H}_{5}\right]$-phenylalanine enrichments are illustrated in Figure 3. Plasma L- $\left[1-{ }^{13} \mathrm{C}\right]$-phenylalanine enrichments (ingested tracer) rapidly increased after ingestion of the test drinks, with the lowest and highest enrichments following ingestion of 10 and $35 \mathrm{~g}$ whey protein, respectively $(\mathrm{P}<0.01)$. The plasma $\mathrm{L}-\left[\mathrm{ring}-{ }_{-}{ }^{2} \mathrm{H}_{5}\right.$ ] phenylalanine enrichment (infused tracer) decreased following whey protein ingestion in all groups, with lower values observed during the early stages following ingestion of 20 and $35 \mathrm{~g}$ when compared with $10 \mathrm{~g}$ whey protein $(\mathrm{P}<0.05)$. Following this initial decrease, plasma L-[ring${ }^{2} \mathrm{H}_{5}$ ]phenylalanine enrichments slowly returned to baseline levels, with higher values following ingestion of $10 \mathrm{~g}$ compared with 20 and $35 \mathrm{~g}$ whey protein $(P<0.05)$.

$\mathrm{L}-\left[1-{ }^{13} \mathrm{C}\right]$ phenylalanine

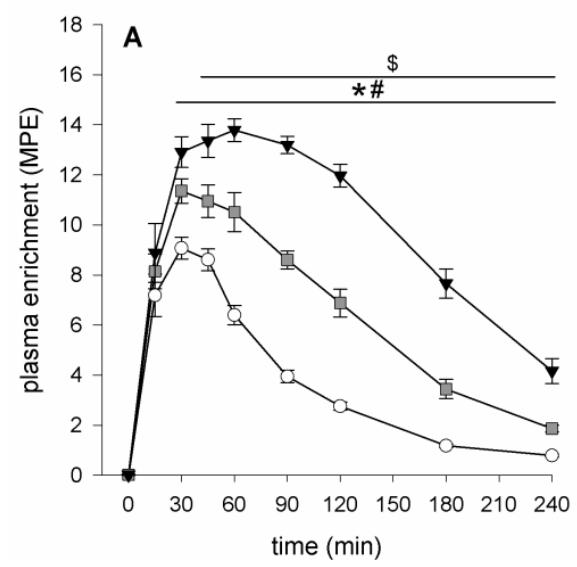

L-[ring- ${ }^{2} \mathrm{H}_{5}$ ]phenylalanine

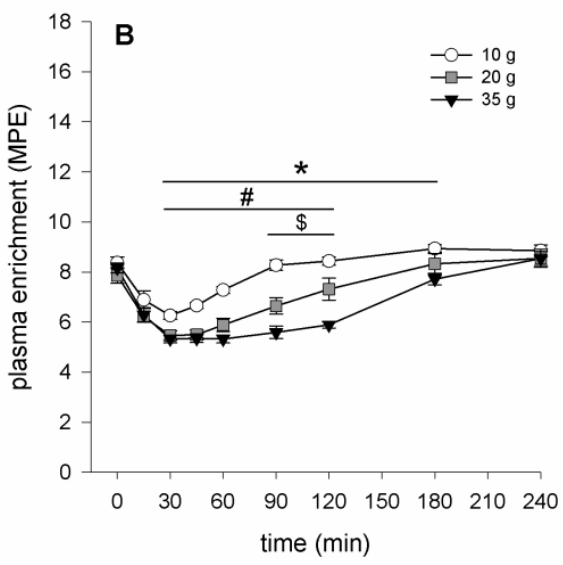

Figure 3. Plasma L- $\left[1-{ }^{13} \mathrm{C}\right]$ phenylalanine $(\mathrm{A})$ and $\mathrm{L}-\left[\right.$ ring- $\left.{ }^{2} \mathrm{H}_{5}\right]$ phenylalanine $(\mathrm{B})$ enrichments expressed as mole percent excess (MPE) following ingestion of $10(n=11), 20(n=11)$, and $35 \mathrm{~g}(n=11)$ whey protein. Values represent means \pm SEM. Data were analyzed with repeated measures ANOVA (time $x$ treatment). In case of a significant interaction, a Bonferroni post-hoc test was applied to locate these differences. Plasma $L-\left[1{ }^{13} C\right]$ phenylalanine enrichments: time effect, $P<0.001$; treatment effect, $P<0.001$; time $x$ treatment interaction, $\mathrm{P}<0.001$. Plasma $\mathrm{L}-\left[\right.$ ring $\left.{ }^{2} \mathrm{H}_{5}\right]$ phenylalanine enrichments: time effect, $\mathrm{P}<0.001$; treatment effect, $P<0.001$; time $x$ treatment interaction, $P<0.001$. *35 g significantly different when compared with $10 \mathrm{~g}, \mathrm{P}<0.05 ;{ }^{\$} 35 \mathrm{~g}$ significantly different when compared with $20 \mathrm{~g}, \mathrm{P}<0.05 ;{ }^{*} 20 \mathrm{~g}$ significantly different when compared with $10 \mathrm{~g}, \mathrm{P}<0.05$. 


\section{Whole-body protein metabolism}

Whole-body protein metabolism over time is presented in Figure 4. Ingestion of the labeled whey protein resulted in a rapid rise in exogenous phenylalanine appearance rate (Figure 4A), with the lowest and highest (peak) values observed following ingestion of 10 and $35 \mathrm{~g}$ whey protein, respectively $(P<0.05)$.

exogenous PHE Ra

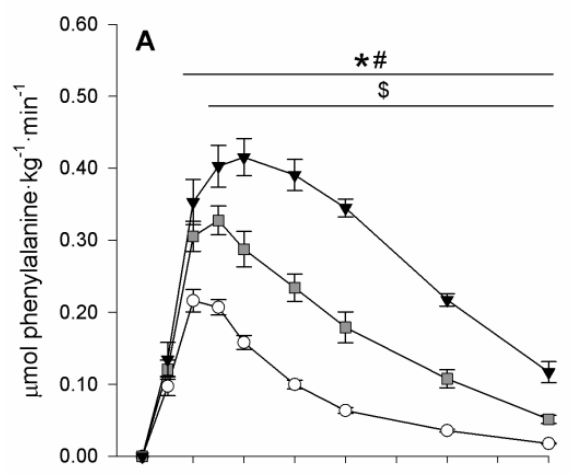

total PHE Rd

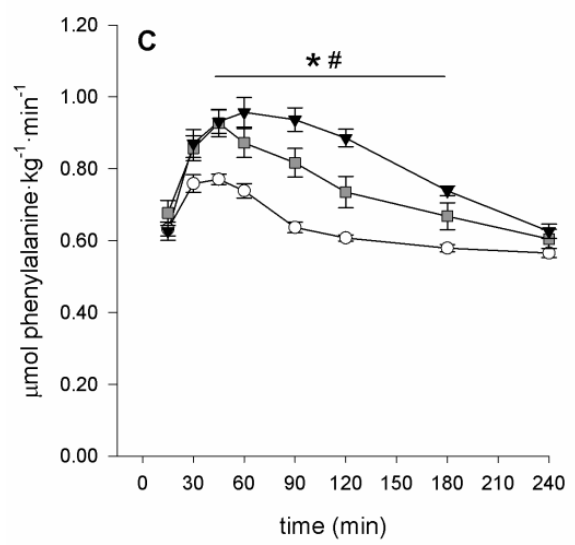

endogenous PHE Ra

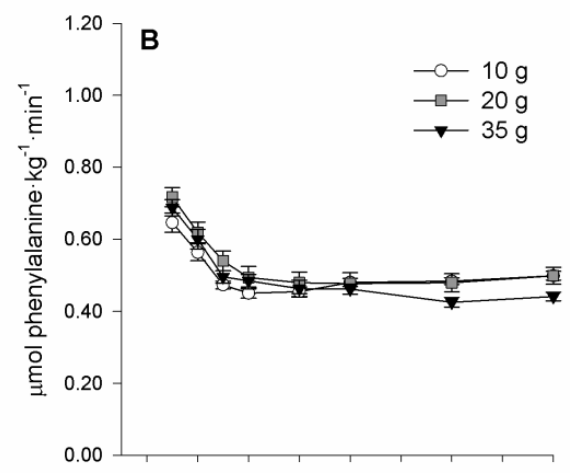

PHE oxidation

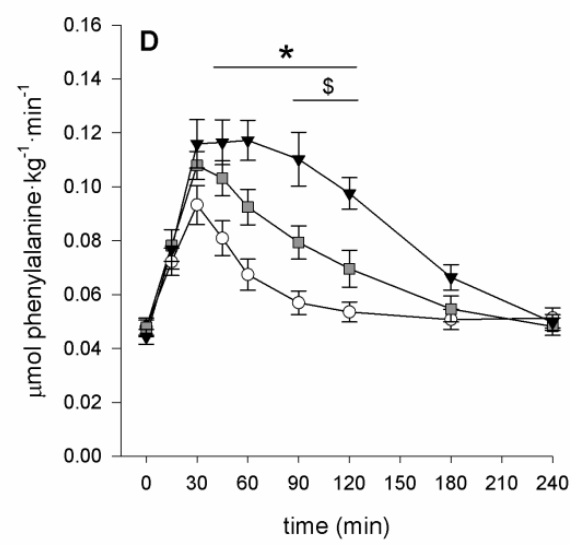

Figure 4. Whole-body phenylalanine kinetics over time following ingestion of $10(n=11), 20$ ( $n=11)$, and $35 \mathrm{~g}(\mathrm{n}=11)$ whey protein $\left(\mu \mathrm{mol}\right.$ phenylalanine $\left.\cdot \mathrm{kg}^{-1} \cdot \mathrm{min}^{-1}\right)$. Exogenous phenylalanine (PHE) appearance rates $(A)$, endogenous phenylalanine (PHE) appearance rates $(B)$, Total phenylalanine (PHE) disappearance rates $(C)$, and phenylalanine (PHE) to tyrosine (TYR) conversion rates (D). Values represent means \pm SEM and are expressed as $\mu \mathrm{mol} \cdot \mathrm{kg}^{-1} \cdot \mathrm{min}^{-1}$. Data were analyzed with repeated measures ANOVA (time $x$ treatment). In case of a significant interaction, a Bonferroni post-hoc test was applied to locate these differences. Exogenous PHE $\mathrm{R}_{\mathrm{a}}$ : time effect, $\mathrm{P}<0.001$; treatment effect, $\mathrm{P}<0.001$; time $\mathrm{x}$ treatment interaction, $\mathrm{P}<0.001$. Endogenous $\mathrm{PHE} \mathrm{R}_{\mathrm{a}}$ : time effect, $\mathrm{P}<0.001$; treatment effect, $\mathrm{P}=0.34$; time $x$ treatment interaction, $\mathrm{P}<0.05$. Total $\mathrm{PHE} \mathrm{R}_{d}$ : time effect, $\mathrm{P}<0.001$; treatment effect, $\mathrm{P}<0.001$; time $\mathrm{x}$ treatment interaction, $\mathrm{P}<0.001$. $\mathrm{PHE}$ to TYR conversion rates: time effect, $\mathrm{P}<0.001$; treatment effect, $\mathrm{P}<0.001$; time $x$ treatment interaction, $\mathrm{P}<0.001$. ${ }^{*} 35 \mathrm{~g}$ significantly different when compared with $10 \mathrm{~g}, \mathrm{P}<0.05$; \$3 g significantly different when compared with $20 \mathrm{~g}, \mathrm{P}<0.05 ;{ }^{\#} 20 \mathrm{~g}$ significantly different when compared with $10 \mathrm{~g}, \mathrm{P}<0.05$. 
Total exogenous phenylalanine appearance, expressed as AUC over $4 \mathrm{~h}$, was calculated as a fraction of the total amount of phenylalanine that was ingested (Equation 4). The fraction of dietary phenylalanine that appeared in the systemic circulation during the $4 \mathrm{~h}$ postprandial period was $61 \pm 1,63 \pm 3$, and $59 \pm 2 \%$ following ingestion of 10, 20, and $35 \mathrm{~g}$ whey protein and did not differ among treatments.

Endogenous phenylalanine appearance rates decreased following whey protein ingestion and did not differ among treatments, though a trend $(P=0.08)$ towards lower values following $35 \mathrm{~g}$ compared with $10 \mathrm{~g}$ was observed at $\mathrm{t}=180-240 \mathrm{~min}$ (Figure 4B). Total phenylalanine disappearance rate (Figure 4C) equals the rate of phenylalanine to tyrosine conversion, which is the first step in phenylalanine oxidation (Figure 4D), and the utilization for protein synthesis. Phenylalanine to tyrosine conversion rates directly increased following whey protein ingestion in all treatments and returned to baseline values by the end of the $4 \mathrm{~h}$ period. The highest amount ( $35 \mathrm{~g}$ ) showed greater values at $\mathrm{t}=45-120$ and $\mathrm{t}=90-120$ min compared with the ingestion of 10 and $20 \mathrm{~g}$ whey protein $(P<0.01)$, respectively.

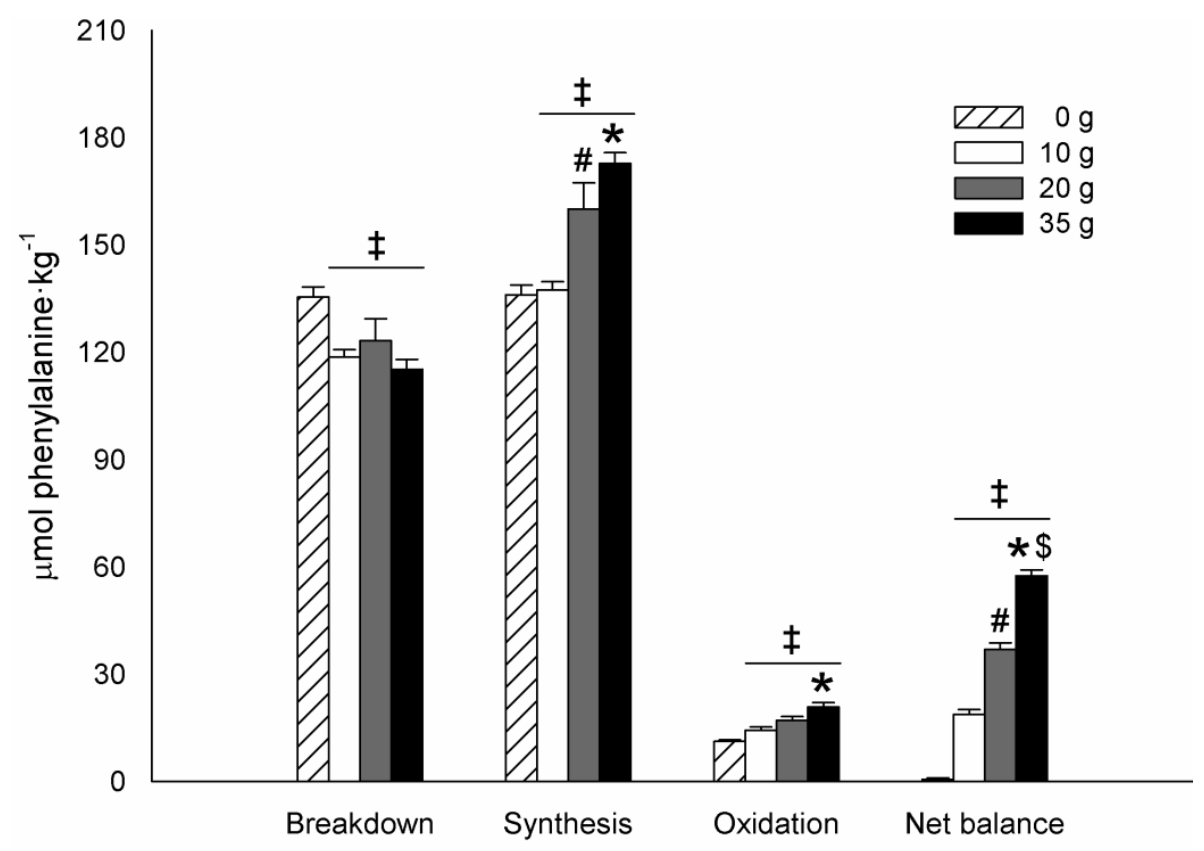

Figure 5. Whole-body protein metabolism expressed as area under the curve (AUC; $\mu$ mol phenylalanine $\left.\cdot \mathrm{kg}^{-1}\right)$ following ingestion of $10(n=11), 20(n=11)$, and $35 \mathrm{~g}(\mathrm{n}=11)$ whey protein. Values represent means \pm SEM. Data were analyzed with ANOVA with Bonferroni correction. *35 g significantly different when compared with $10 \mathrm{~g}, \mathrm{P}<0.05 ;{ }^{\$} 35 \mathrm{~g}$ significantly different when compared with $20 \mathrm{~g}, \mathrm{P}<0.05 ;{ }^{*} 20 \mathrm{~g}$ significantly different when compared with $10 \mathrm{~g}, \mathrm{P}<0.05$; ${ }^{\ddagger}$ significantly different when compared with baseline $(0 \mathrm{~g})$. 
Whole-body protein metabolism expressed as AUC in the basal and postprandial period is presented in Figure 5. Phenylalanine released into the circulation from whole-body protein breakdown, expressed as AUC of Endo $R_{a}$, decreased in all groups to the same extent following protein ingestion when compared with basal values $(P<0.01)$. Phenylalanine utilized for whole-body protein synthesis, expressed as AUC of total $R_{d}$ minus phenylalanine to tyrosine conversion rate, increased in all groups following protein ingestion when compared with basal values $(P<0.05)$. Whole-body protein synthesis was higher following ingestion of 20 and $35 \mathrm{~g}$ when compared with $10 \mathrm{~g}$ whey protein $(\mathrm{P}<0.01)$. Protein oxidation, expressed as AUC of phenylalanine to tyrosine conversion rate, increased in all groups following protein ingestion when compared with basal values $(P<0.01)$. Protein oxidation was higher following ingestion of $35 \mathrm{~g}$ compared with $10 \mathrm{~g}(\mathrm{P}<0.01)$. Whole-body net protein balance increased in all groups following protein ingestion when compared with basal values $(P<0.01)$, with the lowest and highest values observed following ingestion of 10 and $35 \mathrm{~g}$, respectively $(\mathrm{P}<0.01)$.

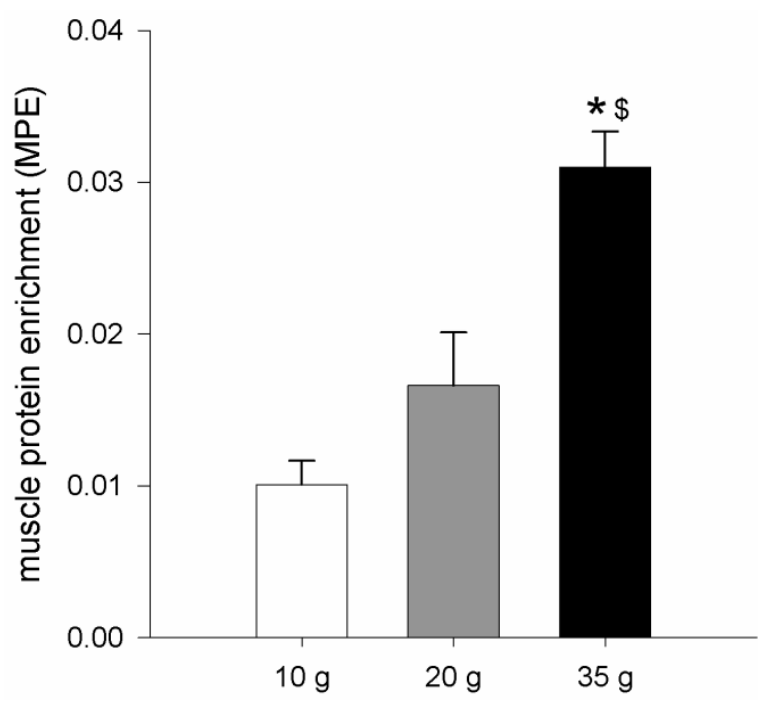

Figure 6. Muscle protein-bound $\mathrm{L}-\left[1-{ }^{13} \mathrm{C}\right]$ phenylalanine enrichments (MPE) following ingestion of 10 $(n=11), 20(n=11)$, and $35 \mathrm{~g}(\mathrm{n}=11)$ whey protein. Values represent means \pm SEM. Data were analyzed with ANOVA with Bonferroni correction. *35 g significantly different when compared with $10 \mathrm{~g}, \mathrm{P}<0.01$; $\$ 35$ g significantly different when compared with $20 \mathrm{~g}, \mathrm{P}<0.05$

\section{Muscle tracer analysis}

The increment in muscle protein-bound L-[ring- $\left.{ }^{2} \mathrm{H}_{5}\right]$ phenylalanine enrichment during the basal period (between the first and the second biopsy) was $0.0059 \pm 0.0005,0.0059 \pm 0.0005$, and $0.0065 \pm 0.0006 \mathrm{MPE}$ in the groups that ingested 10,20 , and $35 \mathrm{~g}$ whey protein, respectively, and did not differ among treat- 
ments. The increment in muscle protein-bound L-[ring- $\left.{ }^{2} \mathrm{H}_{5}\right]$-phenylalanine enrichments in the postprandial period (between the second and third biopsy) was $0.0102 \pm 0.0010,0.0119 \pm 0.0012$, and $0.0136 \pm 0.0009 \mathrm{MPE}$ in the 10, 20, and $35 \mathrm{~g}$ experiment, respectively $(\mathrm{P}=0.08)$. The increment in muscle protein-bound $\mathrm{L}-[1-$ ${ }^{13} \mathrm{C}$ ]phenylalanine enrichments in the postprandial period differed substantially among experiments $(P<0.01$; Figure 6) and was higher following ingestion of $35 \mathrm{~g}$ when compared with $10(P<0.01)$ or $20 \mathrm{~g}(\mathrm{P}<0.05)$ whey protein.

\section{Mixed muscle protein synthesis rates}

Mixed muscle protein synthesis rates are expressed as fractional synthetic rates (FSR) and presented in Table 2. In the basal period, FSR values did not differ among treatments. In contrast, FSR values were significantly different among treatments in the postprandial period $(\mathrm{P}<0.01)$. Ingestion of $35 \mathrm{~g}$ resulted in significantly higher FSR values when compared with basal values $(P<.0 .05)$ or ingestion of $10 \mathrm{~g}$ whey protein $(P<0.05)$.

Table 2. Mixed muscle protein FSR

\begin{tabular}{lccc}
\hline & $\begin{array}{c}10 \mathrm{~g} \\
\text { whey protein } \\
(\mathrm{n}=11)\end{array}$ & $\begin{array}{c}20 \mathrm{~g} \\
\text { whey protein } \\
(\mathrm{n}=11)\end{array}$ & $\begin{array}{c}35 \mathrm{~g} \\
\text { whey protein } \\
(\mathrm{n}=11)\end{array}$ \\
\hline Basal FSR $\left(\% \cdot \mathrm{h}^{-1}\right)$ & $0.035 \pm 0.002$ & $0.037 \pm 0.003$ & $0.039 \pm 0.003$ \\
Postprandial FSR $\left(\% \cdot \mathrm{h}^{-1}\right)$ & $0.029 \pm 0.004$ & $0.041 \pm 0.004$ & $0.052 \pm 0.004^{*} \ddagger$ \\
Difference from basal $(\%)$ & $-1 \pm 14$ & $16 \pm 13$ & $44 \pm 16^{*}$ \\
\hline
\end{tabular}

Mixed muscle protein fractional synthetic rates (FSR) in the fasted, basal period and following ingestion of $10(n=11), 20(n=11)$, and $35 \mathrm{~g}(\mathrm{n}=11)$ whey protein. Values are expressed as means \pm SEM. Data were analyzed with ANOVA. *35 g significantly different when compared with $10 \mathrm{~g}, \mathrm{P}<0.05$; ${ }^{\ddagger}$ significantly different when compared with basal, $\mathrm{P}<0.05$.

\section{Discussion}

In the present study, intrinsically L-[1- $\left.{ }^{13} \mathrm{C}\right]$ phenylalanine-labeled whey protein was used to assess digestion and absorption kinetics of whey protein and its subsequent incorporation in newly synthesized muscle protein in vivo in older males. The present study shows that ingestion of $35 \mathrm{~g}$ whey protein results in greater amino acid absorption and subsequent stimulation of de novo muscle protein synthesis when compared with the ingestion of 10 or $20 \mathrm{~g}$ whey protein in healthy, older men.

Whey protein ingestion has been shown to effectively promote postprandial muscle protein accretion in older adults (8). However, information on the impact of the amount of whey protein ingested by older adults on protein digestion, amino acid absorption, and postprandial muscle protein accretion has not been established. Following the ingestion of 10,20 , and $35 \mathrm{~g}$ intrinsically $\mathrm{L}-\left[1-{ }^{13} \mathrm{C}\right]$ phenylalanine- 
labeled whey protein, a rapid increase in plasma insulin concentrations (Figure 1A), plasma amino acid concentrations (Figure 2), and plasma L- $\left[1-{ }^{13} \mathrm{C}\right]$ phenylalanine enrichments (Figure $3 \mathrm{~A}$ ) was found, with the lowest and highest values observed following ingestion of 10 and $35 \mathrm{~g}$, respectively. By combining plasma phenylalanine concentrations and tracer enrichments, the fraction of dietary phenylalanine that appeared in the circulation was calculated (Equation 4). These fractions were $61 \pm 1,63 \pm 3$, and $59 \pm 2 \%$ in the groups that received 10,20 , and $35 \mathrm{~g}$ whey protein, respectively, and did not differ among treatments. Previous work has suggested that first pass clearance of amino acids by visceral tissues increases with increasing amounts of protein consumed (19). In agreement, when expressed as absolute amounts, $4 \pm 1,8 \pm 1$ and $14 \pm 1 \mathrm{~g}$ of whey-protein derived amino acids were retained in the gut and did not appear in the circulation during the $4 \mathrm{~h}$ postprandial period after ingesting 10, 20, and $35 \mathrm{~g}$ of whey protein, respectively. Despite greater retention in the gut, more amino acids became available in the circulation following ingestion of $35 \mathrm{~g}$ whey protein when compared with the ingestion of 10 or $20 \mathrm{~g}$ whey protein in older men.

Exogenous phenylalanine rates of appearance increased rapidly following whey protein ingestion in all groups, with peak values being reached within 30-60 min (Figure 4A). No other macronutrients were included because we aimed to assess the postprandial response of different amounts of whey protein without possible confounding effects of carbohydrate and/or fat intake on protein digestion and absorption kinetics $(20,21)$. Consequently, non-isocaloric protein drinks were compared and, as a result, different insulin responses were observed between experiments (Figure 1A). Differences in the insulin response are unlikely to have modulated the observed muscle protein synthetic response because increases in plasma EAA concentrations, and not insulin per se, are responsible for stimulating postprandial muscle protein synthesis $(22,23)$. Circulating insulin levels are regarded permissive rather than modulatory with concentrations of $\sim 10-15 \mathrm{mU} \cdot \mathrm{mL}^{-1}$ being required to allow a maximal muscle protein synthetic response $(2,22-24)$. In the present study, plasma insulin levels exceeded these concentrations in all treatments (Figure 1A). In agreement, the observed plasma insulin levels were also sufficient to maximize the inhibition of protein breakdown in all treatments (Figure 5).

Muscle protein fractional synthetic rates (FSR) following whey protein ingestion were calculated under non-steady state conditions which may underestimate (peak) postprandial muscle protein synthesis rates (Table 2). As we more interested in an aggregated $4 \mathrm{~h}$ postprandial response, we also assessed the metabolic fate of whey protein-derived amino acids in de novo muscle protein (Figure 6). Only ingestion of $35 \mathrm{~g}$ whey protein significantly increased muscle protein synthesis rates when compared with baseline values. The latter seems to be at odds with the whole-body kinetics (Figure 5), showing a positive whole-body protein balance in 
all treatments. However, whole-body protein kinetics do not necessarily represent skeletal muscle tissue, as splanchnic tissues and other organs contribute largely to postprandial protein metabolism (19).

The present study shows that ingestion of $35 \mathrm{~g}$ whey protein results in greater amino acid absorption and subsequent use for de novo muscle protein synthesis when compared with the ingestion of 10 or $20 \mathrm{~g}$ whey protein. With habitual protein ingestion in a single meal varying between $10 \mathrm{~g}$ (breakfast) and $35 \mathrm{~g}$ (dinner) in institutionalized and independently living elderly (25), it has been suggested that increasing the amount of protein at breakfast and/or lunch may represent an effective dietary strategy to stimulate postprandial muscle protein accretion and, as such, improve muscle mass preservation in older adults. It should be noted that the dose-response relationship is likely specific for more rapidly digestible protein sources. Previous work from our lab suggests that ingesting greater amounts of more slowly digestible protein does not result in greater amino acid absorption (5, 8). In agreement, we observed a dose-response effect between the amount of protein ingested and subsequent amino acid absorption rates following ingestion of a casein hydrolysate but not intact casein. Besides protein digestion and absorption kinetics, amino acid composition as well as co-ingestion of other macronutrients are likely to modulate the muscle protein synthetic response following meal ingestion. Nonetheless, the presented work clearly underlines the impact of the amount of protein ingested on subsequent amino acid availability and muscle protein synthesis.

In conclusion, the ingestion of $35 \mathrm{~g}$ whey protein results in more amino acids being absorbed and subsequently used for de novo muscle protein synthesis when compared with the ingestion of 10 or $20 \mathrm{~g}$ whey protein. These observations imply that anabolic resistance to food intake in older adults can, at least partly, be compensated for by ingesting a greater amount of whey protein.

\section{Acknowledgements}

We gratefully acknowledge the help of Alexandra Kiskini and Zouhair Ariss for skillful technical assistance and the enthusiastic support of the subjects who volunteered to participate in these experiments.

BP and LJCVL designed the study. BP organized and carried out the clinical experiments with the assistance of BBG, AdL, and AHZ. APG and JMGS performed the stable isotope analyses. BP performed the (statistical) analysis of the data and wrote the manuscript together with LJCVL. None of the authors had a personal or financial conflict of interest. 


\section{References}

1. Koopman R, van Loon UC. Aging, exercise and muscle protein metabolism. J Appl Physiol 2009;106:2040-8.

2. Cuthbertson $D$, Smith $K$, Babraj J, et al. Anabolic signaling deficits underlie amino acid resistance of wasting, aging muscle. FASEB J 2005;19:422-4.

3. Guillet $C$, Prod'homme $M$, Balage $M$, et al. Impaired anabolic response of muscle protein synthesis is associated with S6K1 dysregulation in elderly humans. FASEB J 2004;18:1586-7.

4. Pennings B, Koopman R, Beelen M, Senden JM, Saris WH, van Loon L. Exercising before protein intake allows for greater use of dietary protein-derived amino acids for de novo muscle protein synthesis in both young and elderly men. Am J Clin Nutr 2011;93:322-31.

5. Koopman R, Crombach N, Gijsen AP, et al. Ingestion of a protein hydrolysate is accompanied by an accelerated in vivo digestion and absorption rate when compared with its intact protein. Am J Clin Nutr 2009;90:106-15.

6. Smith GI, Atherton P, Reeds DN, et al. Dietary omega-3 fatty acid supplementation increases the rate of muscle protein synthesis in older adults: a randomized controlled trial. Am J Clin Nutr 2011;93:402-12.

7. Rieu I, Balage $M$, Sornet $C$, et al. Leucine supplementation improves muscle protein synthesis in elderly men independently of hyperaminoacidaemia. J Physiol 2006;575:305-15.

8. Pennings B, Boirie $Y$, Senden JM, Gijsen AP, Kuipers $H$, van Loon $L$. Whey protein stimulates postprandial muscle protein accretion more effectively than do casein and casein hydrolysate in older men. Am J Clin Nutr 2011;93:997-1005.

9. Boirie Y, Gachon P, Corny S, Fauquant J, Maubois JL, Beaufrere B. Acute postprandial changes in leucine metabolism as assessed with an intrinsically labeled milk protein. Am J Physiol 1996;271:E1083-91.

10. Dangin $M$, Boirie $Y$, Guillet $C$, Beaufrere B. Influence of the protein digestion rate on protein turnover in young and elderly subjects. J Nutr 2002;132:3228S-33S.

11. Pennings B, Pellikaan WF, Senden JM, van Vuuren AM, Sikkema J, van Loon LJ. The production of intrinsically labeled milk and meat protein is feasible and provides functional tools for human nutrition research. J Dairy Sci 2011;94:4366-73.

12. Alberti KG, Zimmet PZ. Definition, diagnosis and classification of diabetes mellitus and its complications. Part 1: diagnosis and classification of diabetes mellitus provisional report of a WHO consultation. Diabet Med 1998;15:539-53.

13. Abumrad NN, Rabin D, Diamond MP, Lacy WW. Use of a heated superficial hand vein as an alternative site for the measurement of amino acid concentrations and for the study of glucose and alanine kinetics in man. Metabolism 1981;30:936-40.

14. Van Eijk HM, Rooyakkers DR, Deutz NE. Rapid routine determination of amino acids in plasma by high-performance liquid chromatography with a 2-3 microns Spherisorb ODS II column. J Chromatogr 1993;620:143-8.

15. Wolfe RR, Chinkes DL. Isotope tracers in metabolic research. Wiley-Liss, New York. 2005.

16. Biolo $G$, Tessari $P$, Inchiostro $S$, et al. Leucine and phenylalanine kinetics during mixed meal ingestion: a multiple tracer approach. Am J Physiol 1992;262:E455-63.

17. Husek P. Amino acid derivatization and analysis in five minutes. FEBS Lett 1991;280:354-6.

18. Dangin M, Guillet C, Garcia-Rodenas C, et al. The rate of protein digestion affects protein gain differently during aging in humans. J Physiol 2003;549:635-44.

19. Waterlow JC. Protein turnover. CABI, Oxfordshire 2006.

20. Low AG. Nutritional regulation of gastric secretion, digestion and emptying. Nutr Res Rev 1990;3:229-52.

21. Fouillet H, Gaudichon C, Mariotti F, Bos C, Huneau JF, Tome D. Energy nutrients modulate the splanchnic sequestration of dietary nitrogen in humans: a compartmental analysis. Am J Physiol Endocrinol Metab 2001;281:E248-60. 
22. Bohe J, Low A, Wolfe RR, Rennie MJ. Human muscle protein synthesis is modulated by extracellular, not intramuscular amino acid availability: a dose-response study. J Physiol 2003;552:315-24.

23. Liu Z, Barrett EJ. Human protein metabolism: its measurement and regulation. Am J Physiol Endocrinol Metab 2002;283:E1105-12.

24. Greenhaff PL, Karagounis LG, Peirce N, et al. Disassociation between the effects of amino acids and insulin on signaling, ubiquitin ligases, and protein turnover in human muscle. Am J Physiol Endocrinol Metab 2008;295:E595-604.

25. Tieland M, Borgonjen-Van den Berg KJ, van Loon LJ, de Groot LC. Dietary protein intake in community-dwelling, frail, and institutionalized elderly people: scope for improvement. Eur J Nutr. 2012 Mar;51(2):173-9. 



\section{Chapter 5}

\section{The production of intrinsically labeled milk and meat protein is feasible and provides functional tools for human nutrition research}

Journal of Dairy Science 2011 Sep;94(9):4366-73 


\section{Abstract}

Administration of labeled, free amino acids does not allow direct assessment of in vivo dietary protein digestion and absorption kinetics. Consequently, dietary protein sources with labeled amino acids incorporated within their protein matrix are required. The aim of the present study was to produce intrinsically L-[1${ }^{13} \mathrm{C}$ ]phenylalanine-labeled milk and meat protein that would allow the in vivo assessment of postprandial protein digestion and absorption kinetics in humans. One lactating dairy cow was continuously infused with $420 \mu \mathrm{mol} L$-[1${ }^{13} \mathrm{C}$ ]phenylalanine $\cdot \min ^{-1}$ for $96 \mathrm{~h}$, with plasma and milk being collected before, during, and after isotope infusion. Twenty-four $h$ after infusion, the cow was slaughtered to produce intrinsically labeled meat. Levels of L-[1- $\left.{ }^{13} \mathrm{C}\right]$ phenylalanine enrichment as high as 40 mole percent excess (MPE) in milk and 1.5 MPE in meat protein were achieved. In a subsequent human proof-of-principle experiment, 2 healthy young males ( $25 \pm 1 \mathrm{y} ; 66.2 \pm 5.2 \mathrm{~kg}$ ) each ingested $135 \mathrm{~g}$ intrinsically L-[1${ }^{13} \mathrm{C}$ ]phenyl-alanine-labeled minced beef, after which plasma samples were collected at regular time-intervals. Plasma L- $\left[1-{ }^{13} \mathrm{C}\right]$ phenylalanine enrichments increased during the first 90 min following beef ingestion reaching peak plasma enrichment levels of $0.61 \pm 0.04 \mathrm{MPE}$. Whole-body net protein balance, assessed by continuous infusion of $\mathrm{L}-\left[\right.$ ring- ${ }^{2} \mathrm{H}_{5}$ ]phenylalanine and L-[ring- ${ }^{2} \mathrm{H}_{2}$ ]tyrosine, was higher in the postprandial period when compared with basal values $(6.4 \pm 0.1 \mathrm{vs}-4.5 \pm 0.1 \mu \mathrm{mol} \cdot \mathrm{kg}$ $\left.{ }^{1} \cdot \mathrm{h}^{-1}\right)$. In conclusion, the production of intrinsically $\mathrm{L}-\left[1-{ }^{13} \mathrm{C}\right]$ phenylalanine labeled milk and meat protein is feasible and provides functional tools to investigate in vivo protein digestion and absorption kinetics in humans. 


\section{Introduction}

For many years, stable isotope labeled amino acids have been applied to study protein metabolism in vivo in humans (1). This work has led to important physiological insights and has provided a wealth of practical information on the impact of nutrition in maintaining or increasing lean tissue mass in both health and disease (2). In general, the turnover of a specific amino acid is investigated through isotope dilution via continuous intravenous administration of a labeled amino acid. However, when investigating the impact of feeding on protein metabolism, most groups generally apply a research design in which labeled leucine or phenylalanine is coingested, with or without continuous infusion of an intravenous amino acid tracer. The fact that the oral tracer is being administered as a free amino acid and the bulk of amino acids are provided as intact dietary protein introduces substantial methodological limitations (3). Free amino acids and protein-derived amino acids exhibit an entirely different timing and efficiency of intestinal absorption (4). Therefore, dietary protein with a labeled amino acid incorporated within its protein matrix is warranted to directly assess the digestion and absorption kinetics of dietary protein in vivo in humans. However, such intrinsically labeled dietary protein is not commercially available and only few reports describe the production of stable isotope labeled proteins for more specific purposes (5-8).

Previously, intrinsically labeled milk protein has been produced by intravenous infusion of L-[1- $\left.{ }^{13} \mathrm{C}\right]$ leucine (6) or L- $\left[1-{ }^{13} \mathrm{C}\right]$ phenylalanine (9) in lactating dairy cows. In the latter experiment, L-[1- $\left.{ }^{13} \mathrm{C}\right]$ phenylalanine enrichments in the collected milk protein as high as 29.4 mole percent excess (MPE) were achieved. Such high enrichment levels are necessary when aiming to assess both in vivo protein digestion and absorption kinetics as well as the subsequent postprandial muscle protein synthetic response following ingestion of meal-like amounts (20-35 g) of protein $(10,11)$. As the latter becomes challenging with smaller amounts of dietary protein, we aimed to produce milk proteins with an even greater enrichment level. To allow maintenance of high plasma L- $\left[1-{ }^{13} \mathrm{C}\right]$ phenylalanine levels, a single Holstein-Friesian dairy cow was continuously infused with $400 \mathrm{~g}$ of $\mathrm{L}-\left[1-{ }^{13} \mathrm{C}\right]$ phenylalanine for as much as 4 days ( $96 \mathrm{~h}$ ). Furthermore, an isotonic glucose solution was infused simultaneously to increase the mean extraction rate of plasma L- $\left[1-{ }^{13} \mathrm{C}\right]$ phenylalanine by the mammary gland (12) and improve milk protein production by minimizing the loss of tracer due to hepatic amino acid oxidation (13).

The maximal recovery rate of tracer in milk protein has been estimated to be 25 $28 \%(6,9)$. We hypothesized that the current infusion protocol would also allow a large amount of L-[1- $\left.{ }^{13} \mathrm{C}\right]$ phenylalanine to be incorporated in the skeletal muscle tissue of the animal. As a consequence we speculated whether the L-[1${ }^{13} \mathrm{C}$ ]phenylalanine enrichment of meat protein would be detectable and potentially even allow subsequent application in human nutrition research. Therefore, the cow 
was slaughtered $24 \mathrm{~h}$ after cessation of the stable isotope infusion procedure and the meat was subsequently used in a human proof-of-principle study to determine the potential of assessing beef protein digestion and absorption kinetics in vivo in humans.

In the present study, we extend on our previous work (9) by investigating the potential to produce intrinsically L-[1- $\left.{ }^{13} \mathrm{C}\right]$ phenylalanine-labeled milk protein with an enrichment level that is greater than any previously produced batch of labeled milk protein. Furthermore, we tested the applicability of this approach to produce intrinsically L-[1- $\left.{ }^{13} \mathrm{C}\right]$ phenylalanine-labeled meat protein that would allow the in vivo assessment of protein digestion and absorption kinetics following beef ingestion in humans.

\section{Methods}

\section{Production of intrinsically labeled protein}

\section{Animal}

One lactating Holstein-Friesian dairy cow ( $5^{\text {th }}$ parity, $642 \mathrm{~kg}$ live weight, 40 days in milk at the start of the infusion period) was selected for the production of intrinsically $\mathrm{L}-\left[1-{ }^{13} \mathrm{C}\right]$ phenylalanine-labeled milk and meat protein. During the infusion period, the cow produced $48.6 \pm 0.6 \mathrm{~kg} \mathrm{milk} \cdot \mathrm{day}^{-1}$, with an equivalent amount of $2.05 \pm 0.002$ and $1.38 \pm 0.002 \mathrm{~kg}$ fat and protein $\cdot$ day $^{-1}$, respectively. The animal was fed a mixed ratio of grass silage $(50.8 \% \mathrm{w} / \mathrm{w})$, maize silage $(33.9 \% \mathrm{w} / \mathrm{w})$, corn cob $(11.3 \% \mathrm{w} / \mathrm{w})$, soy-rape seed $\operatorname{mix}(3.4 \% \mathrm{w} / \mathrm{w})$, lime $(0.1 \% \mathrm{w} / \mathrm{w})$, salt $(0.1 \% \mathrm{w} / \mathrm{w})$, and a mineral $\operatorname{mix}(0.3 \% \mathrm{w} / \mathrm{w})$. During the experiment, the cow consumed $23.5 \pm 1.0 \mathrm{~kg}$ dry matter (DM) $\cdot$ day $^{-1}$, which covered $82 \%$ of the net energy lactation (NEL) requirements and $80 \%$ of the protein requirements $(14,15)$. The forage mixture was offered ad libitum 3 times daily allowing $10 \%$ orts. Equal portions of concentrate $\left(7.1 \mathrm{~kg} \mathrm{DM} \cdot \mathrm{day}^{-1}\right)$ were given at 6:00, 14:00, and 22:00. The animal was housed in an individual tie stall and had free access to water. The experiment and animal handling procedures were approved by the Ethics Committee of the Wageningen University under the Dutch Law on Animal Experimentation.

\section{Stable isotope infusion}

The stable isotope $\mathrm{L}-\left[1-{ }^{13} \mathrm{C}\right]$ phenylalanine (99\% enriched) was purchased from Cambridge Isotopes Laboratories (Andover, MA, USA). A total of $400 \mathrm{~g}$ L-[1${ }^{13} \mathrm{C}$ ]phenylalanine tracer was dissolved in $40 \mathrm{~L}$ of an isotonic glucose $(5 \% \mathrm{w} / \mathrm{v})$ solution (Braun Melsungen AG, Germany) with a final concentration of $278 \mathrm{mmol}$ glucose $\cdot \mathrm{L}^{-1}$ and $60.5 \mathrm{mmol} \mathrm{L-}\left[1-{ }^{13} \mathrm{C}\right]$ phenyl-alanine $\cdot \mathrm{L}^{-1}$. Infusates were stored at $4^{\circ} \mathrm{C}$ pending further use. Prior to use, the infusion bags were allowed to warm up to room temperature. 
An outline of the applied infusion protocol is shown in Figure 1. Five days before the start of the tracer infusion ( $d-5)$ the cow was adapted to 3 milkings day $^{-1}(6: 00$, 14:00, and 22:00). Two days prior to tracer infusion (d-2), catheters (Careflow 16 $\mathrm{GA} \times 300 \mathrm{~mm}$ with $18 \mathrm{GA} \times 70 \mathrm{~mm}$ needle introducer; Becton Dickinson, BD, Netherlands) were inserted percutaneously in the right and left jugular vein for intravenous infusion (6.94 $\mathrm{mL} \cdot \mathrm{min}^{-1}$ ) and blood sampling, respectively, as described previously (9). Directly following catheterization, glucose was infused at a rate of 116 $\mathrm{mmol} \cdot \mathrm{h}^{-1}$. After 2 days, the milk from 22:00 (d-1) and 6:00 (d0) was collected (unlabeled milk) and the continuous infusion of glucose and $L\left[1-{ }^{13} \mathrm{C}\right]$ phenylalanine was started directly following the 6:00 milking at d0. This combined glucose and tracer infusion was continued for $96 \mathrm{~h}$ to $6: 00$ at $\mathrm{d} 4$, with $\mathrm{L}-\left[1-{ }^{13} \mathrm{C}\right]$ phenylalanine infused at a rate of $420 \mu \mathrm{mol} \cdot \mathrm{min}^{-1}$. General health of the cow was monitored continuously and all procedures were well-tolerated.

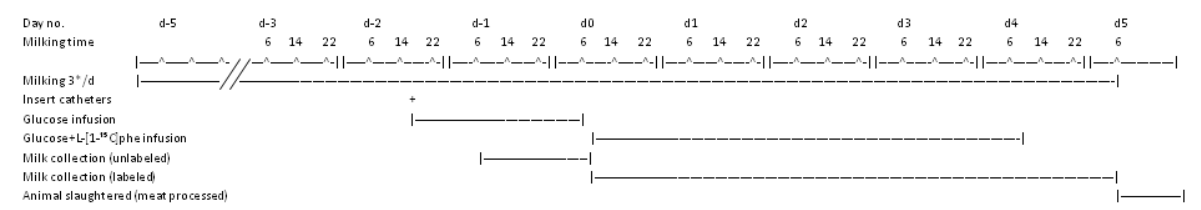

Figure 1. Outline of the cow infusion protocol.

\section{Milk collection}

The cow was milked every $8 \mathrm{~h}$ until $24 \mathrm{~h}$ following cessation of the infusion (d5), with blood samples being obtained at each milking. Milk obtained during each milking was separately collected in $25 \mathrm{~L}$ containers which were directly cooled to $<7^{\circ} \mathrm{C}$, frozen within $24 \mathrm{~h}$ and stored at $-40^{\circ} \mathrm{C}$ within $48 \mathrm{~h}$ until further processing. The processing of the milk was performed at NIZO food research (Ede, The Netherlands) as previously described (9). In short, intrinsically L- $\left[1-{ }^{13} \mathrm{C}\right]$ phenylalaninelabeled milk was fractionated into a casein and a whey protein concentrate. Before the fractionation procedure, collected milk was thawed and pooled in a low and highly labeled batch. The highly labeled batch consisted of milk collected from 22:00 at d0 to 06:00 at d4, i.e. from 16 to $96 \mathrm{~h}$ following the onset of the tracer infusion, respectively. The lower labeled batch consisted of milk collected from 22:00 at d-1 to 06:00 at d0 (unlabeled milk), milk collected at 14:00 at d0 (8 $\mathrm{h}$ following the start of the tracer infusion), and milk collected from 14:00 at d4 to 06:00 at $\mathrm{d} 5$ (24 $\mathrm{h}$ following cessation of the tracer infusion).

\section{Meat collection}

Twenty-four $h$ following the infusion period, the cow was transported to a commercial abattoir (Henk Worst, Nijkerk, The Netherlands) and slaughtered. The carcass was refrigerated at $4 \stackrel{\circ}{ } \mathrm{C}$ for $2 \mathrm{~d}$ postmortem. Thereafter, the carcass was 
deboned and meat cuts from the loin rib, shoulder and leg were weighted in portions of $135 \mathrm{~g}$ and stored at $-18^{\circ} \mathrm{C}$. Before packaging, part of the lean beef was minced. Slaughter and processing of the meat followed strict Food and Consumer Product Safety Authority regulations to assure that no contamination occurred during processing of the meat and that meat products were fully qualified for human consumption.

\section{Cow plasma and protein analyses}

Plasma phenylalanine and tyrosine were derivatized to their t-butyldimethylsilyl (TBDMS) derivatives and their ${ }^{13} \mathrm{C}$ enrichments were determined by electron ionization gas chromatography-mass spectrometry (GC-MS, Agilent 6890N GC/5973N MSD Little Falls, DE, USA) using selected ion monitoring of masses 336 and 337 for unlabeled and labeled L-[1- $\left.{ }^{13} \mathrm{C}\right]$ phenylalanine, respectively; and masses 466, 467, for unlabeled and labeled L-[1- $\left.{ }^{13} \mathrm{C}\right]$ tyrosine, respectively (16).

For measurement of $\mathrm{L}-\left[1-{ }^{13} \mathrm{C}\right]$ phenylalanine and $\mathrm{L}-\left[1-{ }^{13} \mathrm{C}\right]$ tyrosine enrichments in the intrinsically labeled milk protein, $100 \mu \mathrm{L}$ milk was added to $900 \mu \mathrm{L} 2 \%$ ice-cold perchloric acid (PCA). The mixture was vortexed, kept on ice for $10 \mathrm{~min}$ and centrifuged.

The protein pellet was washed with 3 additional $1.5 \mathrm{~mL}$ washes of $2 \%$ PCA, dried and hydrolyzed in $6 \mathrm{M} \mathrm{HCl}$ at $120^{\circ} \mathrm{C}$ for $15-18 \mathrm{~h}$. The hydrolyzed protein fraction was dried under a nitrogen stream while heated to $120^{\circ} \mathrm{C}$, after which $50 \%$ acetic acid solution was added. The hydrolyzed protein was passed over a Dowex exchange resin (AG 50W-X8, 100-200 mesh hydrogen form, Biorad, Hercules, CA, USA) using $2 \mathrm{M} \mathrm{NH}_{4} \mathrm{OH}$. Thereafter, the eluate was dried and the purified amino acids were derivatized to their $\mathrm{N}(\mathrm{O}, \mathrm{S})$-ethoxycarbonyl ethyl esters for the determination of ${ }^{13} \mathrm{C} /{ }^{12} \mathrm{C}$ ratios of milk protein-bound phenylalanine and tyrosine (17). Thereafter, the derivative was measured by GC-C-IRMS (Finnigan MAT 252, Bremen, FRG) using HP Ultra I GC-column (\#19091A-112, Hewlett-Packard, Palo Alto, CA), combustion interface II and monitoring of ion masses 44 and 45.

For measurement of L-[1- $\left.{ }^{13} \mathrm{C}\right]$ phenylalanine enrichment in the intrinsically labeled meat protein, $55 \mathrm{mg}$ meat was freeze-dried. Collagen, blood, and other non-muscle fiber material were removed from the meat under a light microscope. The isolated muscle fiber mass (10-15 mg) was weighed and 8 volumes ( $8 x$ dry weight of isolated muscle fibers $x$ wet/dry ratio) ice-cold $2 \%$ perchloric acid (PCA) were added. The tissue was then homogenized and centrifuged and the meat protein pellet was analyzed similarly as the milk protein pellet.

The protein-bound enrichments of phenylalanine and tyrosine were determined by establishing the relationship between the enrichment of a series of L-[1$\left.{ }^{13} \mathrm{C}\right]$ phenylalanine and $\mathrm{L}-\left[1-{ }^{13} \mathrm{C}\right]$ tyrosine standards of variable enrichment and the enrichment of the $\mathrm{N}(\mathrm{O}, \mathrm{S})$-ethoxycarbonyl ethyl esters of these standards. Standard 
regression curves were applied in all isotopic enrichment analysis to assess for linearity of the mass spectrometer and to control for the loss of tracer.

\section{Human proof-of-principle study}

\section{Subjects}

Two healthy young male volunteers (age: $25 \pm 1 \mathrm{y}$; weight: $66.2 \pm 5.2 \mathrm{~kg}$; BMI: $20.8 \pm 1.6 \mathrm{~kg} \cdot \mathrm{m}^{-2}$; basal glucose: $5.2 \pm 0.3 \mathrm{mmol} \cdot \mathrm{L}^{-1}$; basal insulin: $8.5 \pm 1.8 \mathrm{mU} \cdot \mathrm{L}^{-1}$ ) with no history of participating in any regular exercise program were selected to participate in the present study. Both subjects were informed on the nature and possible risks of the experimental procedures, before their written informed consent was obtained. This study was approved by the Medical Ethics Committee of the Academic Hospital Maastricht.

\section{Protocol}

At 8:00 am, following an overnight fast, subjects arrived at the laboratory by car. A Teflon catheter was inserted into an antecubital vein for stable isotope infusion. A second Teflon catheter was inserted in a heated dorsal hand vein of the contralateral arm and placed in a hot-box $\left(60^{\circ} \mathrm{C}\right)$ for arterialized blood sampling (18). Stable isotopes L-[ring- ${ }^{2} \mathrm{H}_{5}$ ]phenylalanine and L-[ring- ${ }^{2} \mathrm{H}_{2}$ ]-tyrosine were purchased from Cambridge Isotopes (Andover, MA) and dissolved in $0.9 \%$ saline before infusion. Tracer solutions were prepared by the pharmacy of the Academic Hospital Maastricht (Maastricht, The Netherlands) following GMP-standards. Following basal blood collection, the plasma phenylalanine and tyrosine pools were primed with a single intravenous dose of $2 \mu \mathrm{mol} \cdot \mathrm{kg}^{-1} \mathrm{~L}-\left[\mathrm{ring}_{-}{ }^{2} \mathrm{H}_{5}\right.$ ]phenylalanine and $0.775 \mu \mathrm{mol} \cdot \mathrm{kg}$ ${ }^{1} \mathrm{~L}$-[ring- ${ }^{2} \mathrm{H}_{2}$ ]tyrosine. Thereafter, continuous tracer infusion was started with an infusion rate of 0.050 and $0.019 \mu \mathrm{mol} \cdot \mathrm{kg}^{-1} \cdot \mathrm{min}^{-1}$ for L-[ring- ${ }^{2} \mathrm{H}_{5}$ ]phenylalanine and L[ring- ${ }^{2} \mathrm{H}_{2}$ ]tyrosine, respectively. After resting in a supine position for $60 \mathrm{~min}, \mathrm{a}$ second arterialized blood sample was drawn ( $\mathrm{t}=-90 \mathrm{~min})$, marking the start of the post-absorptive period. During the post-absorptive period, arterialized blood samples were collected at $\mathrm{t}=-60,-30$, and $0 \mathrm{~min}$. Subjects then received $135 \mathrm{~g}$ minced beef (containing $26 \mathrm{~g}$ protein). During the postprandial period, arterialized blood samples were collected at $\mathrm{t}=30,60,90,120,150,180,240,300$, and $360 \mathrm{~min}$.

\section{Beef preparation}

Subjects received a portion of $135 \mathrm{~g}$ minced lean beef. Meat was prepared in the kitchen of the department of Human Movement Sciences on the morning of the test day. In short, the minced beef (overnight-thawed in a refrigerator at $4 \circ \mathrm{C}$ ) was grilled until the inner temperature reached $65 \circ \mathrm{C}$. Subjects ingested the beef within $15 \mathrm{~min}$. Subjects were allowed to add salt $(0.5 \mathrm{~g})$ to the beef and drink a glass of water $(200 \mathrm{~mL})$. 


\section{Plasma Analyses}

Plasma $(100 \mu \mathrm{L})$ for amino acid analyses was deproteinized on ice with $10 \mathrm{mg}$ dry 5sulphosalicylic acid, mixed and the clear supernatant was collected after centrifugation. Plasma amino acid concentrations were determined by HPLC, after precolumn derivatization with o-phthaldialdehyde (19). For plasma ring- ${ }^{2} \mathrm{H}$ enrichment measurements, phenylalanine and tyrosine were derivatized to their t-butyldimethylsilyl (TBDMS) derivatives and their ${ }^{2} \mathrm{H}$ enrichments were determined by electron ionization gas chromatography-mass spectrometry (GC-MS, Agilent 6890N GC/5973N MSD Little Falls,DE, USA) using selected ion monitoring of masses 336 and 341 for unlabeled and labeled ( ring- $^{2} \mathrm{H}_{5}$ ) phenylalanine, respectively, and masses 466, 468 and 470 for unlabeled and labeled ( $\mathrm{ring}-{ }^{2} \mathrm{H}_{2}$ and ring- ${ }^{2} \mathrm{H}_{4}$ ) tyrosine, respectively (16). For plasma $1-{ }^{13} \mathrm{C}$ enrichment measurements, phenylalanine was derivatized to its $\mathrm{N}(\mathrm{O}, \mathrm{S})$-ethoxycarbonyl ethyl esters (17). Thereafter, the ratios labeled/unlabeled derivatives were determined by GC-C-IRMS (Finnigan MAT 252, Bremen, Germany). Standard regression curves were applied in all isotopic enrichment analyses to assess for linearity of the mass spectrometer and to control for the loss of tracer. Enrichments were corrected for the presence of all isotopes of the same moiety (20).

\section{Calculations}

Ingestion of L-[1- $\left.{ }^{13} \mathrm{C}\right]$ phenylalanine-labeled beef, intravenous infusion of L-[ring${ }^{2} \mathrm{H}_{5}$ ]phenylalanine and L-[ring- ${ }^{2} \mathrm{H}_{2}$ ]tyrosine, and arterialized blood sampling were used to assess whole-body phenylalanine kinetics in non-steady state conditions. Total, exogenous, and endogenous rate of appearance $\left(R_{a}\right)$ and plasma availability of dietary phenylalanine (i.e., fraction of dietary phenylalanine that appeared in the systemic circulation, Phe $e_{\text {plasmal }}$ ) were calculated using modified Steele's equations $(3,21)$. These parameters were calculated as follows:

$$
\begin{aligned}
& \text { Total } R_{a}=\frac{F-p V \cdot C(t) \cdot \mathrm{d} E_{i v} / \mathrm{d} t}{E_{i v}(t)} \\
& \text { Exo } R_{a}=\frac{\text { Total } \mathrm{R}_{\mathrm{a}} \cdot E_{p o}(t)+p V \cdot \mathrm{d} E_{p o} / \mathrm{d} t}{E_{p r o t}} \\
& \text { Endo } R_{a}=\text { Total } \mathrm{R}_{\mathrm{a}}-\text { Exo } \mathrm{R}_{\mathrm{a}}-\mathrm{F} \\
& \text { Phe } e_{\text {plasma }}=\left(\frac{\mathrm{AUC}_{\text {ExoRa }}}{\text { Phe }_{\text {Prot }}}\right) \cdot B W \cdot 100
\end{aligned}
$$


where $F$ is the intravenous tracer infusion rate $\left(\mu \mathrm{mol} \cdot \mathrm{kg}^{-1} \cdot \mathrm{min}^{-1}\right), p V(0.125)$ is the distribution volume for phenylalanine (3). $C(t)$ is the mean plasma phenylalanine concentration between two time points. $d E_{i v} / d t$ represents the time-dependent variations of plasma phenylalanine enrichment derived from the intravenous tracer and $E_{i v}(t)$ is the mean plasma phenylalanine enrichment from the intravenous tracer between 2 consecutive time points. Exo $R_{a}$ represents the plasma entry rate of dietary phenylalanine, $E_{p o}(t)$ is the mean plasma phenylalanine enrichment for the oral tracer, $d E_{p o} / d t$ represents the time-dependent variations of plasma phenylalanine enrichment derived from the oral tracer and $E_{\text {prot }}$ is the L-[1${ }^{13} \mathrm{C}$ ]phenylalanine enrichment in the dietary protein. Phe $e_{\text {Prot }}$ is the amount of dietary phenylalanine ingested, $A \cup C_{\text {ExoRa }}$ represents the area under the curve (AUC) of Exo $R_{a}$, which corresponds to the amount of dietary phenylalanine that appeared in the blood over a $6 \mathrm{~h}$ period following beef ingestion. BW represents the subjects' body weight in $\mathrm{kg}$.

Total rate of disappearance of phenylalanine (Total $R_{d}$ ) equals the rate of phenylalanine (PHE) to tyrosine (TYR) conversion by hydroxylation (first step in phenylalanine oxidation) and utilization for protein synthesis. These parameters can be calculated as follows:

$$
\begin{aligned}
& \text { Total } R_{d}=\text { Total } R_{a}-p V \cdot \frac{\mathrm{d} C}{\mathrm{~d} t} \\
& \text { PHE to TYR conversion }=\operatorname{Tyr} R_{a} \cdot \frac{E_{t}(t)}{E_{p}(t)} \cdot \frac{\mathrm{Phe} R_{d}}{\left(F_{p}+\mathrm{Phe} R_{d}\right)} \\
& \text { Protein synthesis }=\text { Total } R_{d}-\mathrm{PHE} \text { to TYR conversion } \\
& \text { PHE net balance }=\text { Protein synthesis - Endo } R_{a} \\
& \text { where } P \text { Phe } R_{d} \text { and } T y r R_{a} \text { are the flux rates for phenylalanine and tyrosine, respec- } \\
& \text { tively, } \left.E_{t}(t) \text { and } E_{p}(t) \text { are the mean plasma enrichments of L-[ring- }{ }^{2} \mathrm{H}_{4}\right] \text { tyrosine and L- } \\
& \text { [ring- } \left.{ }_{-}^{2} \mathrm{H}_{5}\right] \text { phenylalanine, respectively, and } F_{p} \text { is the infusion rate of the phenylala- }
\end{aligned}
$$
nine tracer. 


\section{Results}

\section{Production of intrinsically labeled protein}

\section{Plasma analyses}

Infusion of L-[1- $\left.{ }^{13} \mathrm{C}\right]$ phenylalanine in the cow substantially increased plasma L-[1$\left.{ }^{13} \mathrm{C}\right]$ phenylalanine enrichment (Figure 2). During the infusion period, mean plasma $\mathrm{L}-\left[1{ }^{13} \mathrm{C}\right]$ phenylalanine enrichment averaged $37.4 \pm 1.2 \mathrm{MPE}$. As a result of the L-[1$\left.{ }^{13} \mathrm{C}\right]$ phenylalanine infusion, plasma L-[1- $\left.{ }^{13} \mathrm{C}\right]$ tyrosine enrichment also increased during the experiment and averaged 7.0 $\pm 0.4 \mathrm{MPE}$.

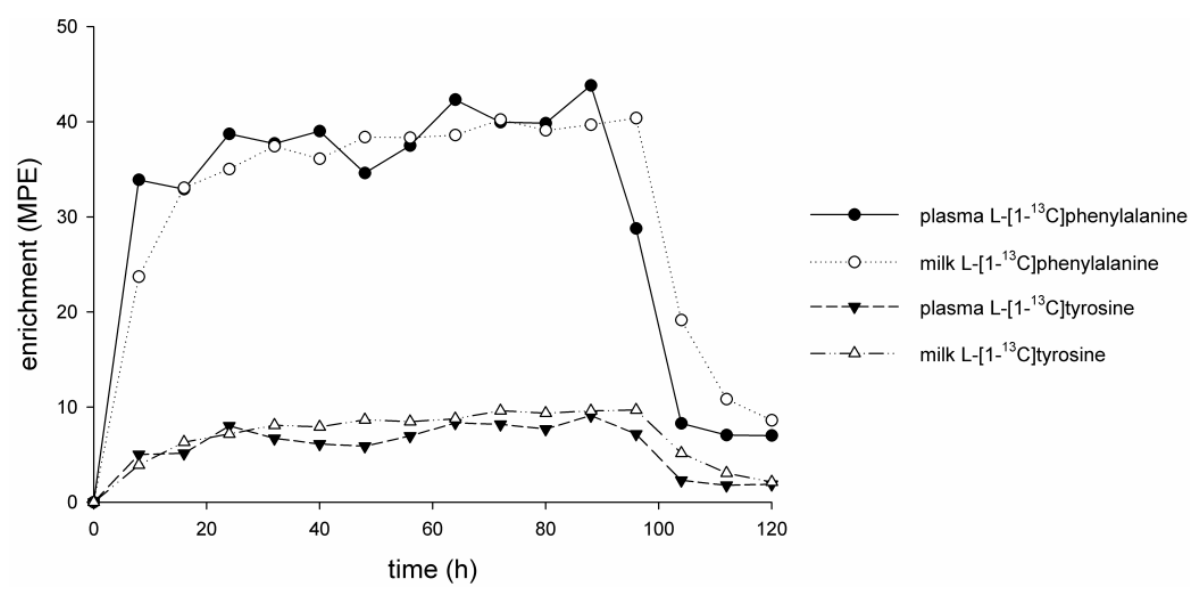

Figure 2. Cow plasma and milk enrichments of L- $\left[1-{ }^{13} \mathrm{C}\right]$ phenylalanine and $\mathrm{L}-\left[1-{ }^{13} \mathrm{C}\right]$ tyrosine obtained before, during, and after the infusion protocol. Values are expressed as mole percent excess (MPE)

\section{Milk analyses}

$\mathrm{L}-\left[1-{ }^{13} \mathrm{C}\right]$ phenylalanine and $\mathrm{L}-\left[1-{ }^{13} \mathrm{C}\right]$ tyrosine enrichments over time are illustrated in Figure 2. Milk L- $\left[1-{ }^{13} \mathrm{C}\right]$ phenylalanine enrichment averaged $36.2 \pm 0.7$ and $10.3 \pm 0.2$ MPE in the high and low labeled batches, respectively. Milk L- $\left[1-{ }^{13} \mathrm{C}\right]$ tyrosine enrichment averaged 8.0 \pm 0.2 and $2.4 \pm 0.1 \mathrm{MPE}$, respectively. The labeled batches provided 178 and $86 \mathrm{~kg}$ milk, respectively. Both batches were successfully fractionated into a high and low labeled casein protein concentrate (36 and $16 \mathrm{~kg}$, respectively) and high and low labeled whey protein concentrate (15 and $13 \mathrm{~kg}$, respectively). The composition of the milk protein concentrates are shown in Table 1 . The total yield of intrinsically L- $\left[1-{ }^{13} \mathrm{C}\right]$ phenylalanine-labeled casein was 3.3 and $1.6 \mathrm{~kg}$ in the high and low labeled batch, respectively. A total of 0.6 and $0.3 \mathrm{~kg}$ of intrinsically $\mathrm{L}-\left[1-{ }^{13} \mathrm{C}\right]$ phenylalanine-labeled whey protein was isolated from the high and low 
labeled batch, respectively. The produced protein concentrates met all food-grade specifications and were subsequently released for human consumption.

Of the $400 \mathrm{~g} \mathrm{~L}-\left[1-{ }^{13} \mathrm{C}\right]$ phenylalanine that were infused in the cow, approximately $105 \mathrm{~g}$ were recovered in the collected milk. Consequently, the recovery rate of tracer in milk protein was calculated to be $26 \%$

Table 1. Composition of the milk protein concentrates

\begin{tabular}{lccc}
\hline Protein concentrate & $\begin{array}{c}\text { Total } \\
\text { protein (\%) }\end{array}$ & $\begin{array}{c}\text { Casein and denatured } \\
\text { whey protein }\end{array}$ & $\begin{array}{c}\text { Native } \\
\text { whey protein (\%) }\end{array}$ \\
\hline High L- $\left[1-{ }^{13} \mathrm{C}\right]$ phe-labeled casein & 9.03 & $8.75(97 \%)$ & $0.28(3 \%)$ \\
Low L- $\left[1-{ }^{13} \mathrm{C}\right]$ phe-labeled casein & 10.40 & $10.10(97 \%)$ & $0.31(3 \%)$ \\
High L- $\left[1-{ }^{13} \mathrm{C}\right]$ phe-labeled whey & 3.81 & $0.28(7 \%)$ & $3.53(93 \%)$ \\
Low L- $\left[1-{ }^{13} \mathrm{C}\right]$ phe-labeled whey & 2.55 & $0.29(11 \%)$ & $2.26(89 \%)$ \\
\hline
\end{tabular}

The amounts of casein of whey protein in the protein concentrates are shown between brackets. ${ }^{1}$ The presence of denatured whey proteins is regarded as nil as the temperature during processing was below the denaturation temperature of whey protein.

\section{Meat analyses}

The mean $\left( \pm\right.$ SEM) L- $\left[1-{ }^{13} \mathrm{C}\right]$ phenylalanine enrichment of the collected lean beef was 1.38 \pm 0.05 MPE. The enrichment of the different meat cuts are shown in Table 2 . Subjects in the human experiment ingested minced beef (from the leg) which had a $\mathrm{L}-\left[1-{ }^{13} \mathrm{C}\right]$ phenylalanine enrichment of $1.47 \pm 0.02 \mathrm{MPE}$.

Table 2. L-[1- $\left.{ }^{13} \mathrm{C}\right]$ phenylalanine enrichment of different meat cuts (loin rib, shoulder and leg) after the labeling procedure.

\begin{tabular}{lc}
\hline & ${\text { Enrichment }(\mathrm{MPE})^{1}}^{1}$ \\
\hline Loin rib & $1.30 \pm 0.03$ \\
Shoulder & $1.37 \pm 0.12$ \\
Leg & $1.47 \pm 0.06$ \\
\hline
\end{tabular}

${ }^{1}$ Enrichments are expressed as mole percent excess (MPE; mean \pm SEM).

Based on a total body mass of $642 \mathrm{~kg}$, the estimated skeletal muscle mass of our cow was $\sim 200 \mathrm{~kg}$. As beef contains $7.5 \mathrm{~g}$ of phenylalanine $\cdot \mathrm{kg}^{-1}(22)$, the recovery rate of tracer in the total skeletal muscle protein pool was approximately $6 \%$.

\section{Human proof-of-principle study}

\section{Plasma analyses}

The time course of the plasma $\mathrm{L}-\left[1-{ }^{13} \mathrm{C}\right]$ phenylalanine and $\mathrm{L}-\left[\mathrm{ring}-{ }^{2} \mathrm{H}_{5}\right]-$ phenylalanine enrichments in the human experiment are illustrated in Figure $\mathbf{3 A}$. 
Plasma L- $\left[1-{ }^{13} \mathrm{C}\right]$ phenylalanine enrichment (derived from the intrinsically labeled meat) rapidly increased following beef ingestion, reaching peak levels after $90 \mathrm{~min}$ $(0.61 \pm 0.04 \mathrm{MPE})$, after which they subsequently declined. The plasma L-[ring${ }^{2} \mathrm{H}_{5}$ ]phenylalanine enrichment decreased following the ingestion of the beef, after which levels returned towards basal values.

\section{Whole-body phenylalanine kinetics}

Ingestion of the intrinsically labeled beef resulted in a rapid increase in the appearance rates of exogenous phenylalanine, reaching peak levels after $120 \mathrm{~min}$ $\left(0.42 \pm 0.01 \mu \mathrm{mol} \cdot \mathrm{kg}^{-1} \cdot \mathrm{h}^{1}\right)$, after which they subsequently declined over time (Figure 3B). In contrast, appearance rates of endogenous phenylalanine decreased over time following ingestion of the beef (Figure $\mathbf{3 C}$ ). The calculated percentage of ingested phenylalanine that appeared in the circulation was $79 \pm 1 \%$. Whole-body net protein balance, calculated using plasma phenylalanine kinetics, was $-4.5 \pm 0.1$ $\mu \mathrm{mol} \cdot \mathrm{kg}^{-1} \cdot \mathrm{h}^{1}$ in the post-absorptive period and $6.4 \pm 0.1 \mu \mathrm{mol} \cdot \mathrm{kg}^{-1} \cdot \mathrm{h}^{1}$ in the postprandial period.
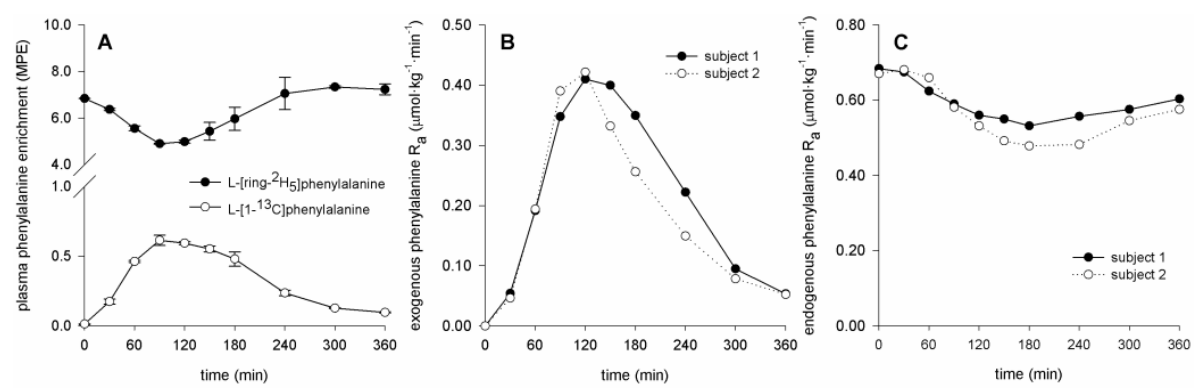

Figure 3. (A) Plasma L-[ring- $\left.{ }^{2} \mathrm{H}_{5}\right]$ phenylalanine and $\mathrm{L}-\left[1-{ }^{13} \mathrm{C}\right]$ phenylalanine enrichments expressed as mole percent excess (MPE); and (B) Exogenous and (C) Endogenous rates of phenylalanine appearance expressed as $\mu \mathrm{mol} \cdot \mathrm{kg}^{-1} \cdot \mathrm{min}^{-1}$ following beef ingestion in the human experiment $(n=2)$. All values represent means \pm SEM.

\section{Discussion}

The present study shows that intrinsically L-[1- $\left.{ }^{13} \mathrm{C}\right]$ phenylalanine-labeled milk and meat protein can be successfully produced by infusing a large amount of L-[1$\left.{ }^{13} \mathrm{C}\right]$ phenylalanine in a lactating dairy cow. Levels of $\mathrm{L}-\left[1-{ }^{13} \mathrm{C}\right]$ phenylalanine enrichment as high as 40 MPE in milk and 1.5 MPE in meat protein were achieved. This level of milk protein enrichment is greater than any previously produced batch of intrinsically labeled milk protein. In addition, this is the first study to report the production of intrinsically labeled meat protein and show its applicability as a functional tool to assess in vivo protein digestion and absorption kinetics following beef ingestion in humans. 
In the present study, we extend on our previous work by investigating the potential to produce intrinsically $\mathrm{L}-\left[1-{ }^{13} \mathrm{C}\right]$ phenylalanine-labeled milk protein with an enrichment level that is greater than any previously produced batch of intrinsically labeled milk protein $(6,9,23)$. Therefore, we applied a different regimen of L-[1${ }^{13} \mathrm{C}$ ]phenylalanine isotope tracer administration to a lactating dairy cow. During tracer infusion, cow plasma L- $\left[1-{ }^{13} \mathrm{C}\right]$ phenyl-alanine enrichments reached levels as high as 37-44 MPE (Figure 2) which were considerably higher than the highest plasma enrichments that have been published previously (9). The high plasma enrichments were closely matched by a comparable rise in milk L-[1${ }^{13} \mathrm{C}$ ]phenylalanine enrichment during tracer infusion (Figure 2). Consequently, the absolute L-[1- $\left.{ }^{13} \mathrm{C}\right]$-phenylalanine enrichment of the milk protein batches obtained in the current experiment were greater than previously reported, and averaged 36.2 versus 29.4 and 10.3 versus 6.1 MPE, in the high and low labeled batches, respectively. The higher tracer enrichment could be attributed to both the longer tracer infusion (i.e. 96 vs 48 h) as well as the co-infusion of glucose. The latter should reduce plasma amino acid oxidation and, as such, maximize the tracer incorporation in endogenous protein (13). Of course, we can only speculate on the impact of glucose co-infusion on the proposed inhibition of amino acid oxidation. As the first step in phenylalanine oxidation is the hydroxylation to tyrosine, the magnitude of this process could be estimated from the accompanying increase in L$\left[1-{ }^{13} \mathrm{C}\right]$ tyrosine enrichment in both cow plasma and milk (Figure 2). The plasma L-[1$\left.{ }^{13} \mathrm{C}\right]$ tyrosine enrichments averaged $5.4 \pm 0.6$ and $7.5 \pm 0.8 \mathrm{MPE}$ in the previous and current experiment, respectively. The latter suggests that there were no large differences in plasma amino acid oxidation between both protocols. Therefore, the higher label enrichment of the milk batches in the present study is likely attributed to the longer tracer infusion protocol. This protocol allowed for a longer time period during which highly labeled milk could be collected, which is of particular relevance as $\mathrm{L}-\left[1-{ }^{13} \mathrm{C}\right]$ phenylalanine milk enrichment takes about $32 \mathrm{~h}$ to reach peak enrichment levels (Figure 2).

The recovery rate of tracer in milk protein was calculated to be $26 \%$, which is in agreement with previous observations $(6,9)$. As only $26 \%$ of the infused tracer was retrieved in the labeled milk, $74 \%$ of the tracer had been directed to other tissues and metabolic processes. We speculated that with a $4 \mathrm{~d}$ infusion protocol a large amount of tracer would also have been incorporated in the muscle protein pool of the cow. Therefore, lean beef was harvested to evaluate whether this isotope tracer administration protocol would also allow the production of intrinsically labeled meat. As a result, labeled beef was obtained with a L- $\left[1-{ }^{13} \mathrm{C}\right]$ phenylalanine enrichment of $1.38 \pm 0.05 \mathrm{MPE}$. This is the first study to report the successful production of intrinsically isotope labeled meat. The level of enrichment is much lower than that observed in the milk protein, which is not surprising considering the relatively low protein turnover rate of skeletal muscle protein when compared with 
the rate of milk protein production in a lactating dairy cow. However, despite a total body mass of $642 \mathrm{~kg}$ and an estimated skeletal muscle mass of more than 200 $\mathrm{kg}$, we obtained a considerable level of muscle tissue $\mathrm{L}-\left[1{ }^{13} \mathrm{C}\right]$ phenylalanine enrichment (Table 2). Theoretically, this level of enrichment should be sufficient to allow assessment of in vivo protein digestion and absorption kinetics following beef ingestion. To confirm the applicability of the intrinsically labeled meat in studying in vivo protein digestion and absorption kinetics, a subsequent proof-of-principle experiment was performed in humans.

In the human experiment, 2 healthy young men were selected to ingest $135 \mathrm{~g}$ of L$\left[1-{ }^{13} \mathrm{C}\right]$ phenylalanine-labeled minced beef. Immediately after ingestion of the minced beef, plasma amino acid concentrations (data not shown) and plasma L-[1${ }^{13} \mathrm{C}$ ]phenylalanine enrichments (Figure $3 \mathrm{~A}$ ) increased. Calculation of the exogenous phenylalanine appearance rate allowed for the direct assessment of dietary phenylalanine that appeared in the circulation during the $6 \mathrm{~h}$ postprandial period (Figure $3 \mathrm{~B}$ ). The percentage of dietary phenylalanine that became available in the circulation was $79 \%$. This percentage tends to be much higher when compared with label retention reported following the ingestion of milk protein (10). Future research, therefore, should compare the bioavailability of dietary protein-derived amino acids between different protein sources. As plasma amino acid availability increased due to the digestion and absorption of the ingested meat, endogenous phenylalanine appearance rates decreased (Figure $3 \mathrm{C}$ ). These changes were indicative for a shift to a more anabolic situation. In fact, when subtracting whole-body protein synthesis rates from whole-body breakdown rates it became apparent that beef ingestion strongly increased whole-body net protein balance $(-4.5 \pm 0.1$ vs $6.4 \pm 0.1 \mu \mathrm{mol} \cdot \mathrm{kg}^{-1} \cdot \mathrm{h}^{-1}$ in the post-absorptive and postprandial period, respectively). Such an increase is in line with previous work that assessed whole-body net protein balance following amino acid or milk protein ingestion $(1,3,4,11,20,21,24)$.

The present study shows that intrinsically L-[1- $\left.{ }^{13} \mathrm{C}\right]$ phenylalanine-labeled milk and meat protein can be successfully produced by infusing a large amount of L-[1$\left.{ }^{13} \mathrm{C}\right]$ phenylalanine in a lactating dairy cow. Levels of $\mathrm{L}-\left[1-{ }^{13} \mathrm{C}\right]$ phenylalanine enrichment as high as 40 MPE in milk and 1.5 MPE in meat protein were achieved. This level of milk protein enrichment is greater than any previously produced batch of intrinsically labeled milk protein. In addition, this is the first study to report the production of intrinsically labeled meat protein and show its applicability as a functional tool to assess in vivo protein digestion and absorption kinetics following beef ingestion in humans. Because dairy and meat are considered high quality and widely consumed protein sources, the applicability of intrinsically labeled milk and meat protein will be instrumental to obtain further insight in human nutrition research. 


\section{Acknowledgements}

The suggestions and help of Miss Ger de Vries-Reijling (Adaptation Physiology Group, Wageningen University) and Miss Inge van Geijlswijk (Veterinary Pharmacy, Utrecht University) to prepare the infusates are highly appreciated, as is true for the discussions with Mr Rob Steenmans (advisor to the committee on the use of experimental animals at Wageningen University) to optimize the experimental conditions. The expert technical assistance of Miss. Marleen Scheer, Mr. Daniel Warner, Mr. Alexandre Carlu, and the staff of the experimental farm 'De Ossekampen' is highly acknowledged. 


\section{References}

1. Wagenmakers AJ. Tracers to investigate protein and amino acid metabolism in human subjects. Proc Nutr Soc 1999;58:987-1000.

2. Koopman R, Saris WH, Wagenmakers AJ, van Loon $\mathrm{U}$. Nutritional interventions to promote postexercise muscle protein synthesis. Sports Med 2007;37:895-906.

3. Boirie Y, Gachon P, Corny S, Fauquant J, Maubois JL, Beaufrere B. Acute postprandial changes in leucine metabolism as assessed with an intrinsically labeled milk protein. Am J Physiol 1996;271:E1083-91.

4. Dangin $M$, Boirie $Y$, Guillet $C$, Beaufrere B. Influence of the protein digestion rate on protein turnover in young and elderly subjects. J Nutr 2002;132:3228S-33S.

5. Berthold HK, Hachey DL, Reeds PJ, Thomas OP, Hoeksema S, Klein PD. Uniformly ${ }^{13}$ C-labeled algal protein used to determine amino acid essentiality in vivo. Proc Natl Acad Sci U S A 1991;88:8091-5.

6. Boirie $\mathrm{Y}$, Fauquant J, Rulquin H, Maubois JL, Beaufrere B. Production of large amounts of $\left[{ }^{13} \mathrm{C}\right]$ leucine-enriched milk proteins by lactating cows. J Nutr 1995;125:92-8.

7. Evenepoel $P$, Hiele $M$, Luypaerts $A$, et al. Production of egg proteins, enriched with L-leucine- ${ }^{13} C_{1}$, for the study of protein assimilation in humans using the breath test technique. J Nutr 1997; 127:327-31.

8. Deglaire A, Moughan PJ, Bos C, Petzke K, Rutherfurd SM, Tome D. A casein hydrolysate does not enhance gut endogenous protein flows compared with intact casein when fed to growing rats. J Nutr 2008;138:556-61.

9. Van Loon LJ, Boirie $\mathrm{Y}, \mathrm{Gijsen} \mathrm{AP}$, et al. The production of intrinsically labeled milk protein provides a functional tool for human nutrition research. J Dairy Sci 2009;92:4812-22.

10. Pennings B, Boirie $Y$, Senden JM, Gijsen AP, Kuipers $H$, van Loon $L$. Whey protein stimulates postprandial muscle protein accretion more effectively than do casein and casein hydrolysate in older men. Am J Clin Nutr 2011.

11. Koopman R, Crombach N, Gijsen AP, et al. Ingestion of a protein hydrolysate is accompanied by an accelerated in vivo digestion and absorption rate when compared with its intact protein. Am J Clin Nutr 2009;90:106-15.

12. Schei I, Danfær A, Boman IA, Volden H. Post-ruminal or intravenous infusions of carbohydrates or amino acids to dairy cows 1 . Early lactation. Animal 2007;1:501-514.

13. Vanhatalo A, Varvikko T, Huhtanen P. Effects of casein and glucose on responses of cows fed diets based on restrictively fermented grass silage. J Dairy Sci 2003;86:3260-70.

14. Tamminga S, Van Straalen WM, Subnel APJ, et al. The Dutch protein evaluation system: the DVE/OEB-system. Livest. Prod. Sci. 1994:139-155.

15. Van Es AJH. Feed evaluation for ruminants. I. The systems in use from May 1977 onwards in The Netherlands. Livestock Prod. Sci. 1978;5:331-345.

16. Wolfe RR, Chinkes DL. Isotope tracers in metabolic research. Wiley-Liss, New York. 2005.

17. Husek P. Amino acid derivatization and analysis in five minutes. FEBS Lett 1991;280:354-6.

18. Abumrad NN, Rabin D, Diamond MP, Lacy WW. Use of a heated superficial hand vein as an alternative site for the measurement of amino acid concentrations and for the study of glucose and alanine kinetics in man. Metabolism 1981;30:936-40.

19. Van Eijk HM, Rooyakkers DR, Deutz NE. Rapid routine determination of amino acids in plasma by high-performance liquid chromatography with a 2-3 microns Spherisorb ODS II column. J Chromatogr 1993;620:143-8.

20. Biolo $G$, Tessari $P$, Inchiostro $S$, et al. Leucine and phenylalanine kinetics during mixed meal ingestion: a multiple tracer approach. Am J Physiol 1992;262:E455-63.

21. Dangin M, Guillet C, Garcia-Rodenas C, et al. The rate of protein digestion affects protein gain differently during aging in humans. J Physiol 2003;549:635-44.

22. Symons TB, Schutzler SE, Cocke TL, Chinkes DL, Wolfe RR, Paddon-Jones D. Aging does not impair the anabolic response to a protein-rich meal. Am J Clin Nutr 2007;86:451-6. 
23. Reitelseder S, Agergaard J, Doessing S, et al. Whey and casein labeled with L- $\left[1-{ }^{13} \mathrm{C}\right]$ leucine and muscle protein synthesis: effect of resistance exercise and protein ingestion. Am J Physiol Endocrinol Metab 2011;300:E231-42.

24. Koopman R, Walrand S, Beelen $\mathrm{M}$, et al. Dietary protein digestion and absorption rates and the subsequent postprandial muscle protein synthetic response do not differ between young and elderly men. J Nutr 2009;139:1707-13. 



\title{
Chapter 6
}

\author{
Minced beef is more rapidly digested and \\ absorbed when compared with beef steak, \\ resulting in greater postprandial protein \\ retention in older men
}

Under review

Bart Pennings

Bart B.L. Groen Jan-Willem van Dijk Anneke de Lange Alexandra Kiskini Marjan Kuklinski Joan M.G. Senden

Luc J.C. van Loon 


\begin{abstract}
Older individuals generally experience a reduced food chewing efficiency. As a consequence, food texture may represent an important factor that modulates dietary protein digestion and absorption kinetics and subsequent postprandial protein balance. The aim of the present study was assess the impact of meat texture on protein digestion and absorption kinetics, exogenous amino acid availability, and subsequent postprandial protein balance in vivo in older men. Ten older men $(74 \pm 2$ y) were randomly assigned to a cross-over experiment that involved 2 treatments in which they consumed $135 \mathrm{~g}$ specifically produced intrinsically L-[1${ }^{13} \mathrm{C}$ ]phenylalanine-labeled beef, provided as beef steak or minced beef. Meat consumption was combined with continuous intravenous L-[ring- ${ }^{2} \mathrm{H}_{5}$ ]phenylalanine and L-[ring- ${ }^{2} \mathrm{H}_{2}$ ]tyrosine infusion to assess beef protein digestion and absorption kinetics as well as whole-body protein synthesis, breakdown, and oxidation rates. Meat protein-derived phenylalanine appeared more rapidly in the circulation following minced beef vs beef steak consumption $(P<0.05)$. Furthermore, a greater amount of meat-derived phenylalanine became available in the systemic circulation during the $6 \mathrm{~h}$ postprandial period following consumption of minced beef vs beef steak ( $61 \pm 3$ vs $49 \pm 3 \%$, respectively; $P<0.01$ ). Whole-body protein balance was more positive following minced beef vs beef steak consumption ( $29 \pm 2$ vs $19 \pm 3 \mu \mathrm{mol}$ phenylalanine $\cdot \mathrm{kg}^{-1}$, respectively; $\mathrm{P}<0.01$ ).

In conclusion, consumption of minced beef is followed by more rapid protein digestion and absorption kinetics when compared with the consumption of beef steak, resulting in increased amino acid availability and greater postprandial protein retention in older men.
\end{abstract}




\section{Introduction}

Aging is accompanied by a progressive decline in skeletal muscle mass, termed sarcopenia (1). Recent work shows that the anabolic response to food intake is impaired in older adults (2-5). This proposed anabolic resistance is now regarded a key-factor in the etiology of sarcopenia.

Dietary protein-derived amino acids serve as the main building blocks for de novo muscle protein synthesis (6). As such, the muscle protein synthetic response to food intake strongly depends on the quantity $(7,8)$ and quality $(9,10)$ of dietary protein consumed. Ingestion of dietary protein stimulates whole-body protein synthesis and inhibits protein breakdown rates, resulting in a positive net protein balance (11). However, the magnitude of this positive protein balance seems to depend on both the rate at which dietary proteins are digested as well as the age of the consumer $(9,12-14)$. Whereas young adults generally show a more positive whole-body protein balance after consumption of slowly digestible protein sources, older adults show a more positive whole-body protein balance after ingestion of more rapidly digestible protein sources $(9,12-14)$.

Meat is considered a high quality and widely consumed protein source. The texture of the consumed meat plays a key-role in chewing efficiency and subsequent bolus formation during mastication (15). Aging has been associated with decreased chewing efficiency, leading to a lower disruption of swallowed meat pieces (16). The consequences of meat texture on dietary protein digestion rate, plasma amino acid availability, and subsequent postprandial protein retention, however, remain to be established.

To directly and accurately assess the appearance rate of dietary protein-derived amino acids from the gut into the circulation, dietary protein with a labeled amino acid incorporated within its protein matrix is warranted (17). However, such intrinsically labeled dietary protein is not commercially available and only few reports describe the production of intrinsic stable isotope-labeled dietary proteins for the purpose of nutrition research (18-20). Recently, we succeeded in producing intrinsically labeled protein by infusing large amounts of $\mathrm{L}-\left[1-{ }^{13} \mathrm{C}\right]$ phenylalanine in a Holstein cow. Besides collecting intrinsically L- $\left[1-{ }^{13} \mathrm{C}\right]$ phenylalanine-labeled milk, we also butchered the cow, thereby obtaining intrinsically labeled meat certified for human consumption (21). The latter is the unique feature of this study and allows us to directly assess meat protein digestion and absorption kinetics in vivo in humans.

In the present study, 10 older men were randomly assigned to a cross-over experiment in which they consumed 135 -g intrinsically L- $\left[1-{ }^{13} \mathrm{C}\right]$-phenylalanine-labeled beef, provided either as a minced beef paddy or as a beef steak. We hypothesized that minced beef is more rapidly digested and absorbed when compared with beef 
steak, resulting in increased amino acid availability and greater postprandial protein retention in older males

\section{Methods}

\section{Subjects}

Ten elderly men (age: $74 \pm 2$ y; weight: $79.3 \pm 3.3 \mathrm{~kg}$; BMI: $26.2 \pm 0.8 \mathrm{~kg} \cdot \mathrm{m}^{-2}$; basal glucose: $5.7 \pm 0.1 \mathrm{mmol} \cdot \mathrm{L}^{-1}$; basal insulin: $16.0 \pm 1.2 \mathrm{mU} \cdot \mathrm{L}^{-1}$ ) participated in this study. All subjects wore dentures for $\geq 6$ months. None of the subjects had a history of participating in any regular exercise program. All subjects were informed on the nature and possible risk of the experimental procedures before their written informed consent was obtained. This study was approved by the Medical Ethics Committee of the Academic Hospital Maastricht.

\section{Pretesting}

Before selection in the study an oral glucose tolerance test (OGTT) was performed to assess glucose tolerance and screen for type 2 diabetes prevalence according to World Health Organization criteria (22). Prior to the OGTT, body weight and height were assessed and body composition was determined by dual-energy X-ray absorptiometry (DXA, Discovery A, Hologic Corporate, Bedford, MA, USA).

\section{Diet and activity prior to testing}

All subjects consumed a standardized meal $\left(32 \pm 2 \mathrm{~kJ} \cdot \mathrm{kg}^{-1}\right.$ body weight, consisting of 55 energy\% (E\%) carbohydrate, $15 \mathrm{E} \%$ protein and $30 \mathrm{E} \%$ fat) the evening prior to the experiment. All volunteers were instructed to refrain from any sort of exhaustive physical activity and to keep their diet as constant as possible $3 \mathrm{~d}$ prior to the experiments.

\section{Protocol}

All subjects were randomly assigned to a cross-over experiment that involved 2 treatments in which they consumed a piece of $135 \mathrm{~g}$ intrinsically L-[1${ }^{13} \mathrm{C}$ ]phenylalanine-labeled beef, either minced as a beef patty or intact as a steak. Both treatments were separated by at least 14 days. Each treatment started at 8.00 am, when overnight-fasted subjects arrived at the laboratory by car or public transportation. A Teflon catheter was then inserted into an antecubital vein for stable isotope infusion. A second Teflon catheter was inserted in a heated dorsal hand vein of the contralateral arm and placed in a hot-box $\left(60^{\circ} \mathrm{C}\right)$ for arterialized blood sampling (23). Following basal blood collection ( $t=-150 \mathrm{~min}$ ), the plasma phenylalanine and tyrosine pools were primed with a single intravenous dose of L[ring- ${ }^{2} \mathrm{H}_{5}$ ]-phenylalanine $\left(2 \mu \mathrm{mol} \cdot \mathrm{kg}^{-1}\right)$ and L-[ring- ${ }^{2} \mathrm{H}_{2}$ ]tyrosine $\left(0.615 \mu \mathrm{mol} \cdot \mathrm{kg}^{-1}\right)$, after which continuous L-[ring- ${ }^{2} \mathrm{H}_{5}$ ]phenylalanine and L-[ring- ${ }^{2} \mathrm{H}_{2}$ ]-tyrosine infusion 
was started $\left(0.050 \pm 0.001\right.$ and $0.015 \pm 0.002 \mu \mathrm{mol} \cdot \mathrm{kg}^{-1} \cdot \mathrm{min}^{-1}$, respectively). After resting in a supine position for $60 \mathrm{~min}$, a second arterialized blood sample was drawn and a muscle biopsy was collected from the vastus lateralis muscle ( $\mathrm{t}=-90$ $\mathrm{min})$. Additional arterialized blood samples $(6 \mathrm{~mL})$ were collected at $\mathrm{t}=-60,-30$, and 0 min with a second muscle biopsy taken at $\mathrm{t}=0 \mathrm{~min}$, marking the end of the fasting, basal period. Subjects then received the meat meal to which they were allowed to add (the same amount of) salt and drink a glass of water. The time that the subjects needed to consume the entire meal was recorded. Following the consumption of the entire meal, subjects filled in a visual analogue scaled (VAS) questionnaire on the effort and time perceived of chewing the meat before swallowing. Arterialized blood samples were collected at $\mathrm{t}=30,60,90,120,150,180,240,300$, and $360 \mathrm{~min}$ following the complete consumption of the meat meal. A third muscle biopsy taken from the vastus lateralis of the contra-lateral limb was obtained at 360 min to mark the end of the postprandial period. Blood samples were collected in EDTA containing tubes and centrifuged at $1000 \mathrm{~g}$ for $5 \mathrm{~min}$ at $4^{\circ} \mathrm{C}$. Aliquots of plasma were frozen in liquid nitrogen and stored at $-80^{\circ} \mathrm{C}$. Muscle biopsies were obtained from the middle region of the vastus lateralis, $15 \mathrm{~cm}$ above the patella and approximately 3 $\mathrm{cm}$ below entry through the fascia, using the percutaneous needle biopsy technique. Muscle samples were dissected carefully and freed from any visible nonmuscle material. The muscle samples were immediately frozen in liquid nitrogen and stored at $-80^{\circ} \mathrm{C}$ until further analysis.

\section{Preparation of intrinsically labeled meat}

Intrinsically L- $\left[1-{ }^{13} \mathrm{C}\right]$ phenylalanine-labeled meat was obtained by infusing a Holstein cow with large quantities of L-[1- $\left.{ }^{13} \mathrm{C}\right]$ phenylalanine as described previously (21). Twenty-four $h$ following the infusion period, the cow was transported to a commercial abattoir (Henk Worst, Nijkerk, The Netherlands) and slaughtered. The carcass was refrigerated at 4 으 $\mathrm{C}$ for $2 \mathrm{~d}$ postmortem. Thereafter, the carcass was deboned and meat cuts from the right leg were weighted in portions of $135 \mathrm{~g}$ and stored at $-18^{\circ} \mathrm{C}$. Before packaging and storage, part of the lean beef was minced to guarantee that meat from the same cut could be provided as a minced beef paddy as well as a beef steak. On the morning of the test day, meat meals were prepared in the kitchen of the department of Human Movement Sciences. In short, the meat meals (overnight-thawed in a refrigerator at 4 으) were grilled until the inner temperature reached $65^{\circ} \mathrm{C}$. The meat met all chemical and bacteriologic specifications for human consumption. The L-[1- $\left.{ }^{13} \mathrm{C}\right]$ phenylalanine enrichment, assessed by gas chromatography combustion isotope ratio mass spectrometry (GC-C-IRMS) after hydrolysis, was $1.47 \pm 0.03$ mole percent excess (MPE). The protein content was $\sim 19$ $\mathrm{g}$ protein per $100 \mathrm{~g}$ (raw) beef. As such, $135 \mathrm{~g}$ beef provided $\sim 26 \mathrm{~g}$ protein and $\sim 2 \mathrm{~g}$ leucine. 


\section{VAS questionnaire}

Following the consumption of the entire meal, subjects filled in a VAS questionnaire on the effort perceived of chewing the meat before swallowing. They specified their answer by indicating a position along a continuous $10-\mathrm{cm}$ line between two end-points, i.e. not much effort $(0 \mathrm{~cm})$ and a lot of effort $(10 \mathrm{~cm})$.

\section{Plasma analyses}

Plasma glucose (Uni Kit III, 07367204, Roche, Basel, Switzerland) concentrations were analyzed with the COBAS-FARA semi-automatic analyzer (Roche). Insulin was analyzed by radio-immunoassay (Insulin RIA kit, LINCO Research Inc., St. Charles, MO, USA). Plasma (100 $\mu \mathrm{L}$ ) for amino acid analyses was deproteinized on ice with $10 \mathrm{mg}$ dry 5-sulphosalicylic acid, mixed and the clear supernatant was collected after centrifugation. Plasma amino acid concentrations were determined by HPLC, after precolumn derivatization with $\mathrm{o}$-phthaldialdehyde (24). For plasma $\operatorname{ring}{ }_{-}{ }^{2} \mathrm{H}$ enrichment measurements, plasma phenylalanine and tyrosine were derivatized to their t-butyldimethylsilyl (TBDMS) derivatives and analyzed by gas chromatography mass spectrometry (GC-MS, Agilent 6890N GC/5973N MSD Little Falls, DE, USA) using selected ion monitoring of masses 336 and 341 for unlabeled and labeled (ring- ${ }^{2} \mathrm{H}_{5}$ ) phenylalanine, respectively; and masses 466, 468 and 470 for unlabeled and labeled (ring- ${ }^{2} \mathrm{H}_{2}$ and ring- ${ }^{2} \mathrm{H}_{4}$ ) tyrosine, respectively (25). For plasma $1-{ }^{13} \mathrm{C}$ enrichment measurements, phenylalanine was derivatized to its $N(O, S)$ ethoxycarbonyl ethyl ester (26). Thereafter, the ratios labeled/unlabeled derivatives were analyzed by gas chromatography combustion isotope ratio mass spectrometry (GC-C-IRMS, Finnigan MAT 252, Bremen, Germany). Standard regression curves were applied in all isotopic enrichment analyses to assess linearity of the mass spectrometer and to control for the loss of tracer.

\section{Muscle analyses}

For measurement of L-[ring- ${ }^{2} \mathrm{H}_{5}$ ]phenylalanine enrichment in the muscle tissue-free amino acid pool and mixed muscle protein, $55 \mathrm{mg}$ of wet muscle was freeze-dried. Collagen, blood, and other non-muscle fiber material were removed from the muscle fibers under a light microscope. The isolated muscle fiber mass (10-15 mg) was weighed and 8 volumes ( $8 \mathrm{x}$ dry weight of isolated muscle fibers $\mathrm{x}$ wet/dry ratio) of ice-cold $2 \%$ perchloric acid (PCA) were added. The tissue was then homogenized and centrifuged. The supernatant was collected and processed in the same manner as the plasma samples, such that tissue-free L-[ring- ${ }^{2} \mathrm{H}_{5}$ ]phenylalanine enrichments could be measured using their TBDMS derivatives on a GC-MS.

The protein pellet was washed with 3 additional $1.5 \mathrm{~mL}$ washes of $2 \%$ PCA, dried and hydrolyzed in $6 \mathrm{M} \mathrm{HCl}$ at $120^{\circ} \mathrm{C}$ for $15-18 \mathrm{~h}$. The hydrolyzed protein fraction was dried under a nitrogen stream while heated to $120^{\circ} \mathrm{C}$, then $50 \%$ acetic acid solution was added, and the hydrolyzed protein was passed over a Dowex exchange resin 
(AG 50W-X8, 100-200 mesh hydrogen form, Biorad, Hercules, CA, USA) using 2M $\mathrm{NH}_{4} \mathrm{OH}$. The eluate was collected and L-[ring- ${ }^{2} \mathrm{H}_{5}$ ] phenylalanine was derivatized to MTBSTFA-phenylethylamine (26). Thereafter, the ratios labeled/unlabeled derivatives were determined by GC-MS. Standard regression curves were applied to assess linearity of the mass spectrometer and to control for loss of tracer.

\section{Calculations}

Ingestion of $\mathrm{L}-\left[1-{ }^{13} \mathrm{C}\right]$ phenylalanine-labeled meat, intravenous infusion of L-[ring${ }^{2} \mathrm{H}_{5}$ ]phenylalanine and L-[ring- ${ }^{2} \mathrm{H}_{2}$ ]tyrosine, and arterialized blood sampling were used to assess whole-body protein metabolism in non-steady state conditions. Total, exogenous, and endogenous phenylalanine rate of appearance $\left(R_{a}\right)$ and plasma availability of dietary phenylalanine (i.e., fraction of dietary phenylalanine that appeared in the systemic circulation, $P$ Phe plasma $_{\text {l }}$ were calculated using modified Steele's equations $(13,27)$. These parameters were calculated as follows:

$$
\begin{aligned}
& \text { Total } R_{a}=\frac{F-p V \cdot C(t) \cdot \mathrm{d} E_{i v} / \mathrm{d} t}{E_{i v}(t)} \\
& \text { Exo } R_{a}=\frac{\text { Total } \mathrm{R}_{\mathrm{a}} \cdot E_{p o}(t)+p V \cdot \mathrm{d} E_{p o} / \mathrm{d} t}{E_{p r o t}} \\
& \text { Endo } R_{a}=\text { Total } \mathrm{R}_{\mathrm{a}}-\text { Exo } \mathrm{R}_{\mathrm{a}}-\mathrm{F} \\
& \text { Phe }_{\text {plasma }}=\left(\frac{\mathrm{AUC}_{\text {ExoRa }}}{\text { Phe }_{\text {Prot }}}\right) \cdot B W \cdot 100
\end{aligned}
$$

where $F$ is the intravenous tracer infusion rate $\left(\mu \mathrm{mol} \cdot \mathrm{kg}^{-1} \cdot \mathrm{min}^{-1}\right), p V(0.125)$ is the distribution volume for phenylalanine (27). $C(t)$ is the mean plasma phenylalanine concentration between two time points. $d E_{i v} / d t$ represents the time-dependent variations of plasma phenylalanine enrichment derived from the intravenous tracer and $E_{i v}(t)$ is the mean plasma phenylalanine enrichment from the intravenous tracer between two consecutive time points. Exo $R_{a}$ represents the plasma entry rate of dietary phenylalanine, $E_{p o}(t)$ is the mean plasma phenylalanine enrichment for the oral tracer, $d E_{p o} / d t$ represents the time-dependent variations of plasma phenylalanine enrichment derived from the oral tracer and $E_{\text {prot }}$ is the L-[1${ }^{13} \mathrm{C}$ ]phenylalanine enrichment in the dietary protein. Phe $e_{\text {Prot }}$ is the amount of dietary phenylalanine ingested, $A \cup C_{\text {ExoRa }}$ represents the area under the curve (AUC) of Exo $R_{a}$, which corresponds to the amount of dietary phenylalanine that appeared in 
the blood over the $6 \mathrm{~h}$ period following meat consumption. BW represents the subjects' body weight in $\mathrm{kg}$.

Total rate of disappearance of phenylalanine (Total $R_{d}$ ) equals the rate of phenylalanine (PHE) to tyrosine (TYR) conversion by hydroxylation (first step in phenylalanine oxidation) and utilization for protein synthesis. These parameters can be calculated as follows:

$$
\begin{aligned}
& \text { Total } R_{d}=\text { Total } R_{a}-p V \cdot \frac{\mathrm{d} C}{\mathrm{~d} t} \\
& \text { PHE to TYR conversion }=\operatorname{Tyr} R_{a} \cdot \frac{E_{t}(t)}{E_{p}(t)} \cdot \frac{\text { Phe } R_{d}}{\left(F_{p}+\text { Phe } R_{d}\right)} \\
& \text { Protein synthesis }=\text { Total } R_{d}-\text { PHE to TYR conversion } \\
& \text { PHE net balance }=\text { Protein synthesis }- \text { Endo } R_{a}
\end{aligned}
$$

where Phe $R_{d}$ and Tyr $R_{a}$ are the flux rates for phenylalanine and tyrosine, respectively, $E_{t}(t)$ and $E_{p}(t)$ are the mean plasma enrichments of L-[ring- ${ }^{2} \mathrm{H}_{4}$ ]tyrosine and L[ring- ${ }^{2} \mathrm{H}_{5}$ ]phenylalanine, respectively, and $F_{p}$ is the infusion rate of the phenylalanine tracer.

The fractional rate of mixed muscle protein synthesis (FSR) was calculated in $\% \cdot \mathrm{h}^{-1}$ by the precursor-product method (25):

$$
F S R=\frac{\Delta E_{p}}{E_{\text {precursor }} \cdot t} \cdot 100
$$

where $\Delta E_{p}$ is the delta increment of muscle protein-bound L-[ring${ }^{2} \mathrm{H}_{5}$ ]phenylalanine during the incorporation period. $E_{\text {precursor }}$ is the average plasma L[ring- ${ }^{2} \mathrm{H}_{5}$ ]phenylalanine enrichment during the time period for determination of amino acid incorporation. $t$ indicates the time interval $(h)$ between biopsies.

\section{Statistics}

A two-way repeated measures ANOVA with time and treatment as within-subject factors was used to assess differences between treatments over time (time $x$ treatment interaction). In case of a significant time $x$ treatment interaction, pairwise comparisons for individual time points were applied to locate differences between treatments. For non-time dependent variables, a paired t-test was used to compare differences between treatments. 
We hypothesized that minced beef is more rapidly digested and absorbed when compared with beef steak, resulting in increased amino acid availability and greater postprandial protein retention in older males. As such, the primary outcomes for evaluating the study hypothesis were exogenous PHE $R_{a}$ and whole-body net protein balance.

The sample size calculation, with a two-sided significance level of 0.05 and a power of 0.8 , was based on differences in protein digestion and absorption kinetics as described previously (14). Sample size was estimated at $n=10$. Statistical significance was set at $\mathrm{P}<0.05$. All calculations were performed using the SPSS 19.0.1.1 software package. All data are expressed as means \pm SEM.

\section{Results}

\section{Meal consumption time and VAS questionnaire}

The subjects required more time to consume the beef steak than the minced beef, $14.4 \pm 2.6$ and $5.1 \pm 0.4 \mathrm{~min}$, respectively $(P<0.01)$. In addition, the subjects reported via the VAS questionnaires that it took them more effort to chew the beef steak before swallowing when compared with the minced beef, $7.8 \pm 0.9$ vs $1.0 \pm 0.4 \mathrm{~cm}$ $(P<0.01)$.

\section{Plasma analyses}

Plasma insulin concentrations increased following meat consumption, peaking at 90 min and returning back to baseline levels by 240 min with no differences between treatments (Figure 1).

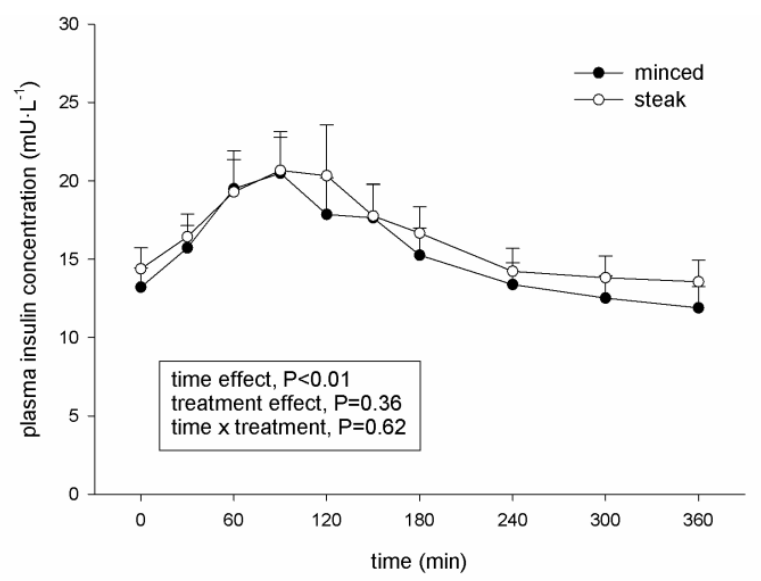

Figure 1. Plasma insulin concentrations (mU $L-1)$ after consumption of minced beef (minced) or beef steak (steak) in older adults $(n=10)$. Values represent means+SEM. Data were analyzed with a two-way repeated measures ANOVA with time and treatment as within subject factors. 
Plasma glucose concentrations did not change over time or between treatments and averaged $5.1 \pm 0.1 \mathrm{mmol} \cdot \mathrm{L}^{-1}$ for both treatments. Plasma phenylalanine, leucine, and essential amino acid (EAA) concentrations over time are illustrated in Figure 2. Plasma EAA concentrations increased following meat consumption and peaked at $120 \mathrm{~min}$. No differences were observed between treatments.
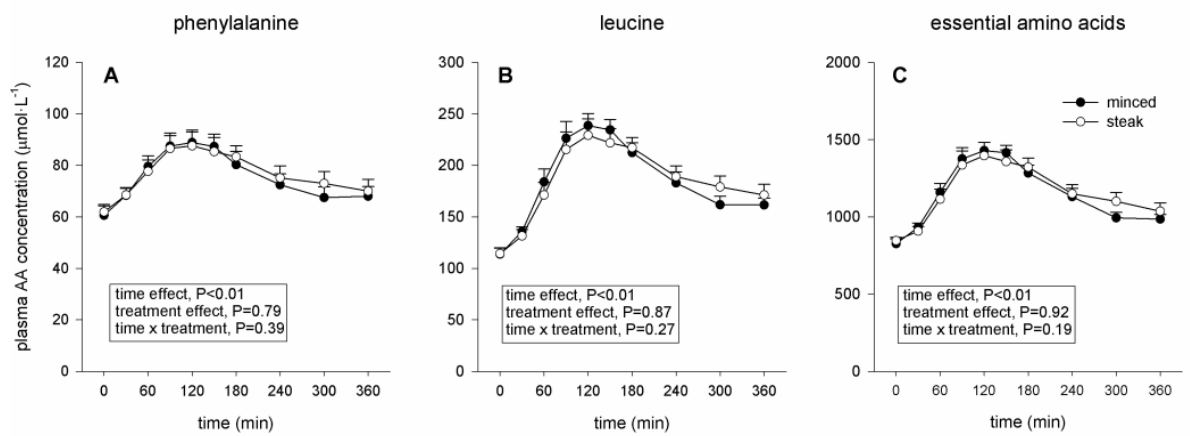

Figure 2. Plasma phenylalanine (A), leucine (B), and essential amino acid (EAA; $C$ ), concentrations $\left(\mu \mathrm{mol} \cdot \mathrm{L}^{-1}\right)$ after consumption of minced beef (minced) or beef steak (steak) in older adults $(n=10)$. Values represent means+SEM. Data were analyzed with a two-way repeated measures ANOVA with time and treatment as within subject factors.

The time course of plasma L-[1- $\left.{ }^{13} \mathrm{C}\right]$ phenylalanine and L-[ring- $\left.{ }^{2} \mathrm{H}_{5}\right]$-phenylalanine enrichments are illustrated in Figure 3.

L- $\left[1-{ }^{13}\right.$ C]phenylalanine

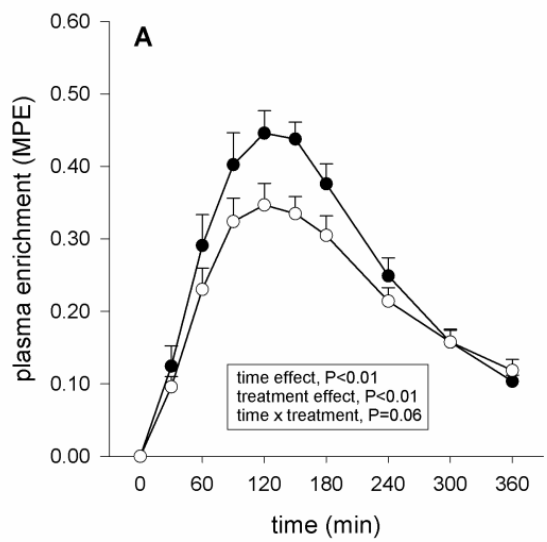

L-[ring- $\left.{ }^{2} \mathrm{H}_{5}\right]$ phenylalanine

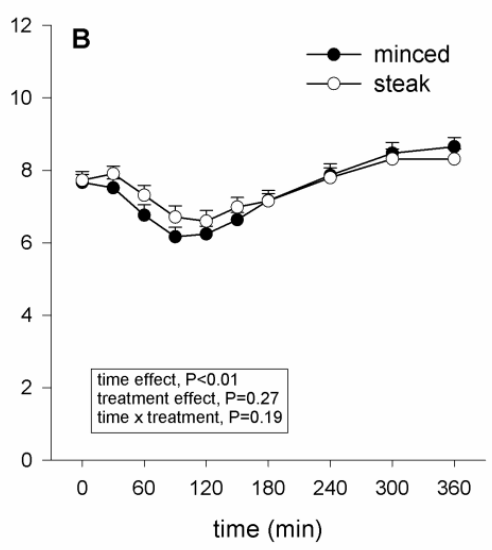

Figure 3. Plasma L- $\left[1-{ }^{13} \mathrm{C}\right]$ phenylalanine $(\mathrm{A})$ and $\mathrm{L}-\left[\mathrm{ring}_{-}{ }^{2} \mathrm{H}_{5}\right]$ phenylalanine $(\mathrm{B})$ enrichments expressed as molar percent excess (MPE) after consumption of minced beef (minced) or beef steak (steak) in older adults $(n=10)$. Values represent means+SEM. Data were analyzed with a two-way repeated measures ANOVA with time and treatment as within subject factors. 
Plasma L-[1- $\left.{ }^{13} \mathrm{C}\right]$ phenylalanine enrichments (intrinsically labeled meat proteinderived phenylalanine) rapidly increased after consumption of the test meals, with a higher average enrichment observed after minced beef consumption when compared with beef steak $(\mathrm{P}<0.01)$. The plasma $\mathrm{L}$-[ring- $\left.{ }^{2} \mathrm{H}_{5}\right]$-phenylalanine enrichments (from continuous L-[ring- ${ }^{2} \mathrm{H}_{5}$ ] phenylalanine infusion) initially decreased following beef consumption but slowly returned to baseline levels by the end of the postprandial period. No differences were observed in plasma L-[ring- ${ }^{2} \mathrm{H}_{5}$ ]phenylalanine enrichments between treatments.

\section{Whole-body protein kinetics}

Whole-body protein kinetics over time are presented in Figure 4. Total PHE $R_{a}$ (Figure 4A) equals the rate of exogenous PHE $R_{a}$ (Figure 4B) and endogenous PHE $R_{a}$ (Figure $4 \mathrm{C}$ ). Consumption of the labeled beef resulted in a rapid rise in exogenous PHE $R_{a}$, with higher (peak) values observed between 60 and 180 min for minced beef when compared with beef steak $(P=0.03)$.
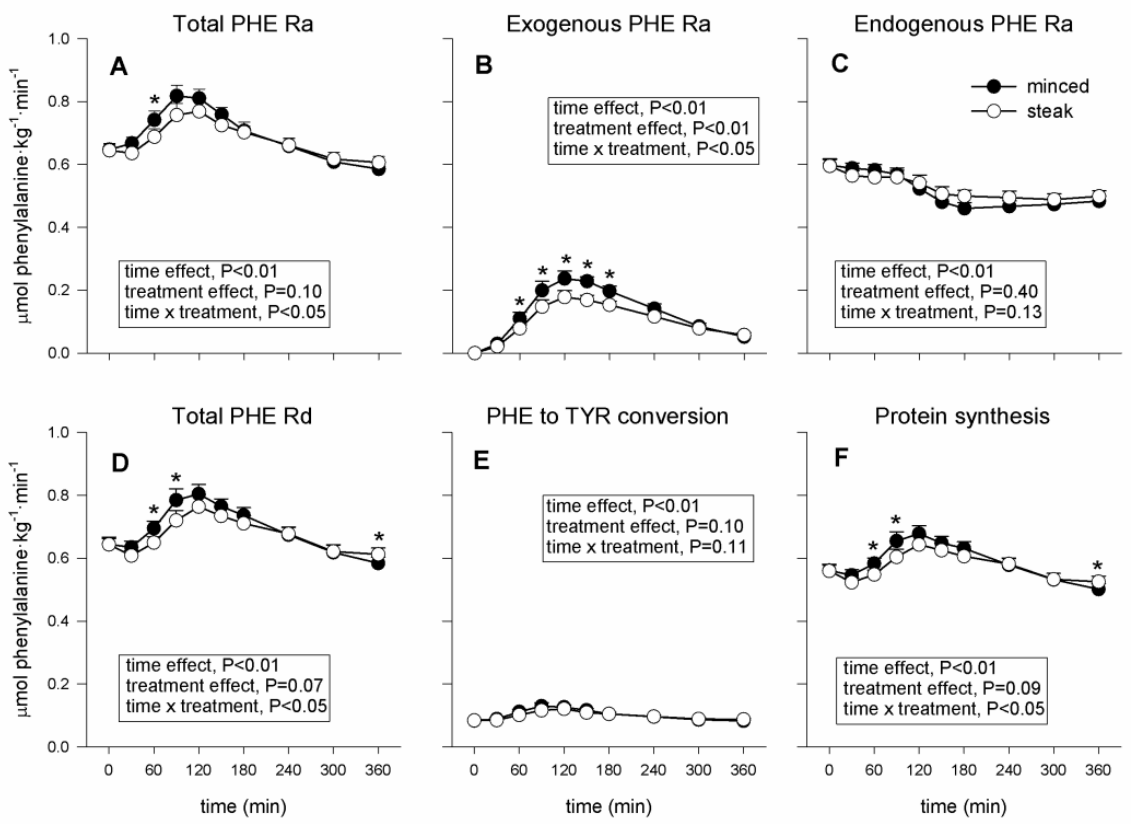

Figure 4. Whole-body phenylalanine (PHE) kinetics over time after consumption of minced beef (minced) or beef steak (steak) in older adults $(n=10)$. Total PHE appearance rates (Ra; A), exogenous PHE Ra (B), endogenous PHE Ra (C), total PHE disappearance rates (Rd; D), PHE to tyrosine (TYR) conversion rates $(E)$, and $\mathrm{PHE}$ utilization rates for protein synthesis (F). Values represent means+SEM and are expressed as $\mu \mathrm{mol}$ phenylalanine $\cdot \mathrm{kg}^{-1} \cdot \mathrm{min}^{-1}$. Data were analyzed with a two-way repeated measures ANOVA with time and treatment as within subject factors. In case of a significant time $\mathrm{x}$ treatment interaction, pairwise comparisons for individual time points were applied to locate differences between treatments. ${ }^{*}$ minced beef significantly different when compared with beef steak, $P<0.05$. 
Total exogenous PHE appearance, expressed as AUC over the $6 \mathrm{~h}$ postprandial period, was calculated as the fraction of the total amount of phenylalanine that was ingested (Equation 4). The fraction of dietary phenylalanine that appeared in the systemic circulation during the $6 \mathrm{~h}$ postprandial period was $61 \pm 3$ and $49 \pm 3 \%$ after minced beef and beef steak consumption, respectively $(P<0.01)$. Endogenous PHE $R_{a}$ decreased after beef consumption and did not differ between treatments. Total PHE $R_{d}$ (Figure 4D) equals the rate of PHE to TYR conversion, which is the first step in phenylalanine oxidation (Figure 4E), and the utilization for protein synthesis (Figure 4F). PHE to TYR conversion rates directly increased after beef consumption in both treatments and returned to baseline values by the end of the $6 \mathrm{~h}$ postprandial period. No differences were observed between treatments. Phenylalanine utilized for whole-body protein synthesis increased after beef consumption in both treatments with higher values observed between 60 and 90 min for minced beef when compared with beef steak $(P=0.02)$.

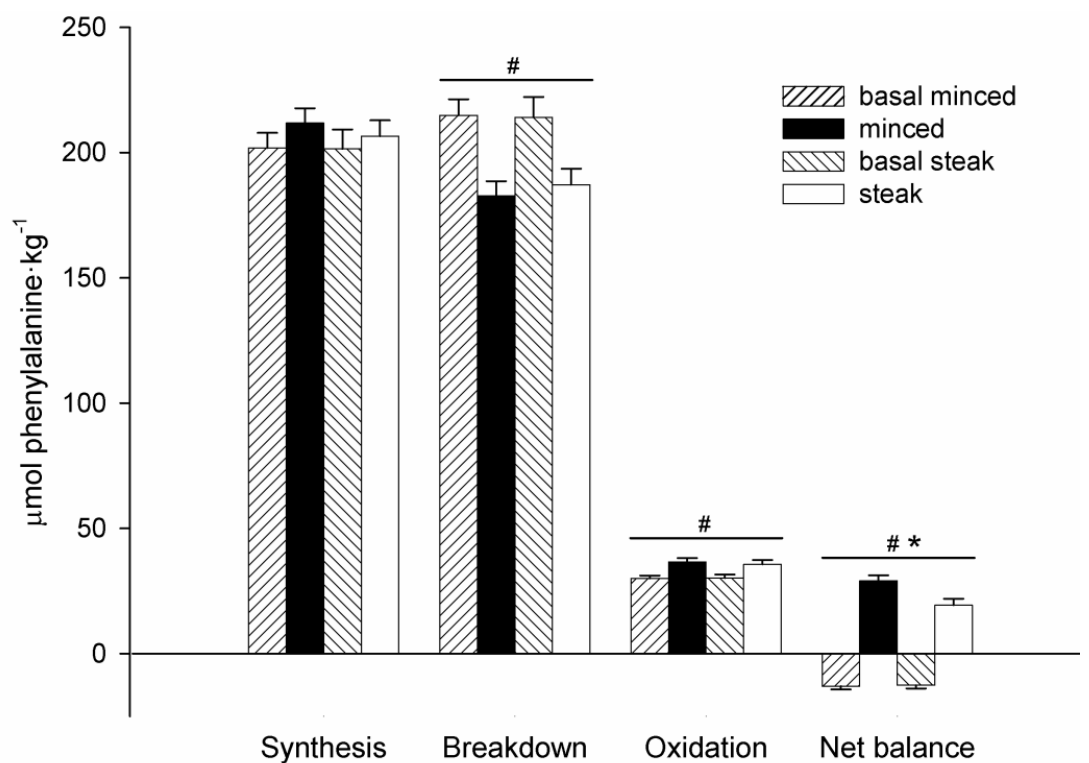

Figure 5. Whole-body protein metabolism expressed as area under the curve (AUC; $\mu$ mol phenylalanine $\cdot \mathrm{kg}^{-1}$ ) after consumption of minced beef (minced) or beef steak (steak) in older adults $(\mathrm{n}=10)$. Values represent means+SEM. Data were analyzed with a two-way repeated measures ANOVA with time (basal or postprandial) and treatment (minced or steak) as within subject factors. Synthesis: time effect, $\mathrm{P}=0.08$; treatment effect, $\mathrm{P}=0.20$; time $\mathrm{x}$ treatment interaction, $\mathrm{P}=0.38$. Breakdown: time effect, $\mathrm{P}<0.01$; treatment effect, $P=0.55$; time $x$ treatment interaction, $P=0.34$. Oxidation: time effect, $P<0.01$; treatment effect, $P=0.66$; time $x$ treatment interaction, $P=0.28$. Net balance: time effect, $P<0.01$; treatment effect, $\mathrm{P}<0.05$; time $\mathrm{x}$ treatment interaction, $\mathrm{P}<0.01$. " postprandial significantly different when compared with basal, $\mathrm{P}<0.01 ;{ }^{*}$ minced beef significantly different when compared with beef steak, $\mathrm{P}<0.01$. 
Whole-body protein synthesis, breakdown, oxidation, and net balance in the basal and postprandial period are presented in Figure 5. Whole-body protein synthesis was expressed as AUC of PHE utilization rate for protein synthesis (Figure 4F), No differences were observed for whole-body protein synthesis, although there was a trend for greater protein synthesis after beef consumption when compared with basal values $(P=0.08)$. Phenylalanine released into the circulation from whole-body protein breakdown, expressed as AUC of endogenous PHE $R_{a}$ (Figure 4C), was lower after beef consumption when compared with basal values $(P<0.01)$. No differences were observed between treatments. Whole-body protein oxidation, expressed as AUC of PHE to TYR conversion rate (Figure 4E), was higher after beef consumption when compared with basal values $(P<0.01)$. No differences were observed between treatments. Whole-body net protein balance equals synthesis minus breakdown. The net protein balance was higher after beef consumption when compared with basal values $(P<0.01)$, with a more positive net protein balance observed after minced beef consumption when compared with beef steak $(P<0.01)$.

\section{Muscle tracer analysis and calculations}

Mixed muscle protein-bound L-[ring- ${ }^{2} \mathrm{H}_{5}$ ]phenylalanine enrichments and fractional synthetic rates (FSR) are presented in Table 1. One subject experienced the muscle biopsy procedure as highly unpleasant and continued the experiment without it, as such, muscle data are presented for $n=9$. Basal FSR values did not differ between treatments and are presented as group average for both treatments. No differences were observed between treatments or between basal and postprandial FSR.

Table 1. Mixed muscle protein enrichments and FSR

\begin{tabular}{lcc}
\hline & $\begin{array}{c}\text { Minced } \\
(\mathrm{n}=9)\end{array}$ & $\begin{array}{c}\text { Steak } \\
(\mathrm{n}=9)\end{array}$ \\
\hline Enrichment biopsy 2 (MPE) & $0.0044 \pm 0.0007$ & $0.0049 \pm 0.0008$ \\
Enrichment biopsy 3 (MPE) & $0.0211 \pm 0.0019$ & $0.0192 \pm 0.0038$ \\
Basal FSR $\left(\% \cdot \mathrm{h}^{-1}\right)$ & $0.035 \pm 0.005$ & $0.035 \pm 0.005$ \\
Postprandial FSR $\left(\% \cdot \mathrm{h}^{-1}\right)$ & $0.035 \pm 0.004$ & $0.034 \pm 0.003$ \\
\hline
\end{tabular}

Mixed muscle protein-bound L-[ring- ${ }^{2} \mathrm{H}_{5}$ ]phenylalanine enrichments in molar percent excess (MPE) and mixed muscle protein fractional synthetic rates (FSR) in the fasted, basal period and after consumption of minced beef $(n=9)$ or beef steak $(n=9)$. Values are expressed as means \pm SEM. Data were analyzed with a two-way repeated measures ANOVA with time and treatment as within subject factors. No differences were observed between treatments or between basal and postprandial FSR.

\section{Discussion}

In the present study, intrinsically L- $\left[1-{ }^{13} \mathrm{C}\right]$ phenylalanine-labeled beef was ingested, in combination with continuous intravenous infusion of $\mathrm{L}$-[ring- $\left.{ }_{-}^{2} \mathrm{H}_{5}\right]$-phenylalanine 
and L-[ring- ${ }^{2} \mathrm{H}_{2}$ ]tyrosine, to assess postprandial protein kinetics after minced beef or beef steak consumption in older males.

Meat texture plays a major role in chewing efficiency and bolus formation during mastication (15). In agreement, it took our subjects more time to consume the beef steak than it did to consume the minced beef $(14.4 \pm 2.6$ and $5.1 \pm 0.4 \mathrm{~min}$, respectively). The postprandial measuring period was started after complete consumption of the meat meal, and may explain why the postprandial increases in plasma insulin (Figure 1) and EAA (Figure 2) concentrations after beef consumption did not differ substantially between treatments. However, as we applied intrinsically L-[1${ }^{13} \mathrm{C}$ ]phenylalanine-enriched meat, we were able to assess the specific release of meat-derived phenylalanine into the circulation. In accordance, we observed a rapid rise in plasma L- $\left[1-{ }^{13} \mathrm{C}\right]$ phenylalanine enrichment after meat ingestion (Figure $3 \mathrm{~A})$. The average plasma $\mathrm{L}-\left[1-{ }^{13} \mathrm{C}\right]$ phenylalanine enrichment showed a greater increase after consumption of minced beef when compared with beef steak. In agreement, subsequent calculation of meat-derived phenylalanine appearance rates showed a more rapid digestion and absorption of meat protein after consumption of minced beef when compared with beef steak (Figure 4B). The latter clearly shows that meat texture can modulate postprandial protein digestion and absorption kinetics in older males.

It has previously been suggested that consumption of more rapidly digestible protein results in a greater stimulation of postprandial protein retention in older adults when compared with the consumption of more slowly digestible protein (12, $13,28,29)$. This concept had been developed by assessing the digestion and absorption kinetics of whey (fast) vs casein (slow) protein (30). However, as these proteins differ in both digestion and absorption kinetics as well as in amino acid composition, we revisited this concept by establishing differences in digestion and absorption kinetics and postprandial muscle protein synthesis after the ingestion of intact casein vs hydrolysed casein $(9,14)$. In line with our previous work, we observed more rapid protein digestion and absorption after ingestion of minced beef vs beef steak, as evidenced by a more rapid postprandial rise in circulating exogenous phenylalanine (Figure 4B). Furthermore, it also resulted in differences in digestion and absorption efficiency between minced beef and beef steak. As we applied the use of intrinsically $L-\left[1-{ }^{13} \mathrm{C}\right]$ phenylalanine-labeled beef combined with continuous intravenous infusion of L-[ring- ${ }^{2} \mathrm{H}_{5}$ ]phenylalanine and L-[ring- $\left.{ }^{2} \mathrm{H}_{2}\right]$ tyrosine, we were able to determine the fraction of meat-derived phenylalanine that appeared in the circulation during the postprandial period (Equation 4). As a result, we show that more meat-derived phenylalanine became available after

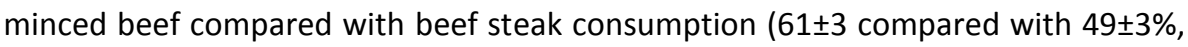
respectively) during the 6-h postprandial period. Such a difference could be of substantial relevance for the stimulation of postprandial protein retention in the older adult. 
It has been well established that the consumption of a meal-like amount of dietary protein increases protein synthesis and inhibits protein breakdown, thereby resulting in a (more) positive net protein balance during the postprandial phase (11). In agreement, consumption of $135 \mathrm{~g}$ beef was shown to do the same (Figure 5). However, the postprandial protein balance was more positive after the consumption of minced beef when compared with beef steak. This finding seems to be the result of small, but consistent differences in whole-body protein synthesis and breakdown rates between treatments and are likely attributed to the more rapid digestion and absorption kinetics and subsequent greater plasma availability of minced beefderived amino acids. In support, previous work has shown that meat protein utilization for protein synthesis is reduced when chewing efficiency is impaired in elderly subjects (31). Taken together, we conclude that minced beef consumption is more effective when compared with beef steak consumption to augment postprandial protein retention in elderly men.

Skeletal muscle protein synthesis is highly responsive to food intake (6). However, the muscle protein synthetic response to food intake has been shown to be impaired in the older population (2-4). This anabolic resistance of aging is now believed to contribute to the progressive loss of muscle mass with aging. In the present study, we did not observe a significant increase in muscle protein FSR above baseline values during the $6 \mathrm{~h}$ period after consuming $135 \mathrm{~g}$ beef ( $26 \mathrm{~g}$ protein) in our elderly subjects (Table 1). Therefore, the texture of the meat consumed seems irrelevant from the perspective of stimulating muscle protein synthesis in older adults. However, as postprandial muscle protein synthesis rates generally peak at 1-2 $\mathrm{h}$ after food intake (32), it is possible that a small, temporary rise in muscle protein synthesis rates remained undetected in the present study. In retrospect, a lack of meal-stimulated muscle FSR may not be surprising considering the fact that the postprandial rise in circulating plasma leucine concentrations plays a key-role in the regulation of muscle protein synthesis $(9,33,34)$. We observed an attenuated rise in plasma leucine concentration after beef consumption (Figure 2B) when compared to responses reported after the ingestion of similar amounts of casein or whey protein $(7,9,14)$. After beef consumption, it took approximately 2 hours for plasma leucine concentrations to reach $234 \pm 14 \mu \mathrm{mol} \cdot \mathrm{L}^{-1}$. This is considerably less than peak plasma leucine concentrations that tend to exceed $500 \mu \mathrm{mol} \cdot \mathrm{L}^{-1}$ within 60 min after ingesting $35 \mathrm{~g}$ whey protein ( $\sim \mathrm{g}$ leucine) (7) or a leucine-enriched EAA supplement ( $3 \mathrm{~g}$ leucine) (35). Based on the absence of a significant increase in muscle protein synthesis rates after the ingestion of 10 and $20 \mathrm{~g}$ as opposed to $35 \mathrm{~g}$ whey protein in elderly men (7), we speculate that ingestion of $135 \mathrm{~g}$ minced beef or beef steak ( 2 g leucine) simply does not allow a sufficient rise in plasma leucine concentration to increase postprandial muscle protein synthesis rates above basal levels. Consequently, beef could be considered a less optimal protein source from the perspective of optimizing postprandial muscle protein synthesis. 
Additional dietary protein sources are needed or a greater amount of (minced) beef should be ingested in a single meal to effectively augment postprandial muscle protein synthesis rates in the older adult. The latter, however, seems less practical as elderly individuals would have to consume close to $200 \mathrm{~g}$ of beef in a single meal.

We conclude that consumption of minced beef is followed by more rapid protein digestion and amino acid absorption when compared with the consumption of beef steak, resulting in increased amino acid availability and greater postprandial protein retention in older men. These data are the first to apply intrinsically labeled beef to show that meat texture can modulate postprandial protein kinetics. Future clinical trials are warranted to evaluate the clinical relevance of food texture and mastication in muscle mass maintenance for the older population.

\section{Acknowledgements}

We gratefully acknowledge the help of Annemie Gijsen and Zouhair Ariss for skillful technical assistance and the enthusiastic support of the subjects who volunteered to participate in these experiments.

BP and LJCVL designed the study. BP organized and carried out the clinical experiments with the assistance of BBLG, AdL, AK, and MK. JMGS performed the stable isotope analyses. BP, BBLG and JWVD performed the (statistical) analysis of the data. BP wrote the manuscript together with LJCVL. None of the authors had a personal or financial conflict of interest 


\section{References}

1. Cruz-Jentoft AJ, Baeyens JP, Bauer JM, Boirie Y, Cederholm T, Landi F, Martin FC, Michel JP, Rolland Y, Schneider SM, et al. Sarcopenia: European consensus on definition and diagnosis: Report of the European Working Group on Sarcopenia in Older People. Age Ageing 2010;39:412-23.

2. Cuthbertson D, Smith K, Babraj J, Leese G, Waddell T, Atherton P, Wackerhage H, Taylor PM, Rennie MJ. Anabolic signaling deficits underlie amino acid resistance of wasting, aging muscle. FASEB J 2005;19:422-4.

3. Guillet C, Prod'homme M, Balage M, Gachon P, Giraudet C, Morin L, Grizard J, Boirie Y. Impaired anabolic response of muscle protein synthesis is associated with S6K1 dysregulation in elderly humans. FASEB J 2004;18:1586-7.

4. Volpi E, Mittendorfer B, Rasmussen BB, Wolfe RR. The response of muscle protein anabolism to combined hyperaminoacidemia and glucose-induced hyperinsulinemia is impaired in the elderly. J Clin Endocrinol Metab 2000;85:4481-90.

5. Wilkes EA, Selby AL, Atherton PJ, Patel R, Rankin D, Smith K, Rennie MJ. Blunting of insulin inhibition of proteolysis in legs of older subjects may contribute to age-related sarcopenia. Am J Clin Nutr 2009;90:1343-50.

6. Rennie MJ, Edwards RH, Halliday D, Matthews DE, Wolman SL, Millward DJ. Muscle protein synthesis measured by stable isotope techniques in man: the effects of feeding and fasting. Clin Sci (Lond) 1982;63:519-23.

7. Pennings B, Groen B, de Lange A, Gijsen AP, Zorenc AH, Senden JM, van Loon LJ. Amino acid absorption and subsequent muscle protein accretion following graded intakes of whey protein in elderly men. Am J Physiol Endocrinol Metab 2012;302:E992-9.

8. Moore DR, Robinson MJ, Fry JL, Tang JE, Glover El, Wilkinson SB, Prior T, Tarnopolsky MA, Phillips $\mathrm{SM}$. Ingested protein dose response of muscle and albumin protein synthesis after resistance exercise in young men. Am J Clin Nutr 2009;89:161-8.

9. Pennings B, Boirie $Y$, Senden JM, Gijsen AP, Kuipers $H$, van Loon $\sqcup$. Whey protein stimulates postprandial muscle protein accretion more effectively than do casein and casein hydrolysate in older men. Am J Clin Nutr 2011;93:997-1005.

10. Burd NA, Yang Y, Moore DR, Tang JE, Tarnopolsky MA, Phillips SM. Greater stimulation of myofibrillar protein synthesis with ingestion of whey protein isolate $v$. micellar casein at rest and after resistance exercise in elderly men. Br J Nutr. 2012 Sep 28;108(6):958-62.

11. Koopman R, van Loon UC. Aging, exercise and muscle protein metabolism. J Appl Physiol 2009;106:2040-8.

12. Dangin $M$, Boirie $Y$, Guillet $C$, Beaufrere B. Influence of the protein digestion rate on protein turnover in young and elderly subjects. J Nutr 2002;132:3228S-33S.

13. Dangin M, Guillet C, Garcia-Rodenas C, Gachon P, Bouteloup-Demange C, Reiffers-Magnani K, Fauquant J, Ballevre O, Beaufrere B. The rate of protein digestion affects protein gain differently during aging in humans. J Physiol 2003;549:635-44.

14. Koopman R, Crombach N, Gijsen AP, Walrand S, Fauquant J, Kies AK, Lemosquet S, Saris WH, Boirie $\mathrm{Y}$, van Loon $\mathrm{L}$. Ingestion of a protein hydrolysate is accompanied by an accelerated in vivo digestion and absorption rate when compared with its intact protein. Am J Clin Nutr 2009;90:106-15.

15. Mioche $L$, Bourdiol P, Monier S. Chewing behaviour and bolus formation during mastication of meat with different textures. Arch Oral Biol 2003;48:193-200.

16. Mioche L, Bourdiol P, Monier S, Martin JF, Cormier D. Changes in jaw muscles activity with age: effects on food bolus properties. Physiol Behav 2004;82:621-7.

17. Metges CC, El-Khoury AE, Selvaraj AB, Tsay RH, Atkinson A, Regan MM, Bequette BJ, Young VR. Kinetics of $L-\left[1-{ }^{13} \mathrm{C}\right]$ leucine when ingested with free amino acids, unlabeled or intrinsically labeled casein. Am J Physiol Endocrinol Metab 2000;278:E1000-9.

18. Boirie Y, Fauquant J, Rulquin H, Maubois JL, Beaufrere B. Production of large amounts of $\left[{ }^{13} \mathrm{C}\right]$ leucine-enriched milk proteins by lactating cows. J Nutr 1995;125:92-8. 
19. Evenepoel P, Hiele M, Luypaerts A, Geypens B, Buyse J, Decuypere E, Rutgeerts P, Ghoos Y. Production of egg proteins, enriched with L-leucine- ${ }^{13} \mathrm{C}_{1}$, for the study of protein assimilation in humans using the breath test technique. J Nutr 1997;127:327-31.

20. Grusak MA, Pezesghi S. Uniformly ${ }^{15} \mathrm{~N}$-labeled soybean seeds produced for use in human and animal nutrition studies: description of a recirculating hydrophonic system and whole plant nutrient and environmental requirements. J Sci Food Agric 1994;64:223-230.

21. Pennings B, Pellikaan WF, Senden JM, van Vuuren AM, Sikkema J, van Loon LJ. The production of intrinsically labeled milk and meat protein is feasible and provides functional tools for human nutrition research. J Dairy Sci 2011;94:4366-73.

22. Alberti KG, Zimmet PZ. Definition, diagnosis and classification of diabetes mellitus and its complications. Part 1: diagnosis and classification of diabetes mellitus provisional report of a WHO consultation. Diabet Med 1998;15:539-53.

23. Abumrad NN, Rabin D, Diamond MP, Lacy WW. Use of a heated superficial hand vein as an alternative site for the measurement of amino acid concentrations and for the study of glucose and alanine kinetics in man. Metabolism 1981;30:936-40.

24. Van Eijk HM, Rooyakkers DR, Deutz NE. Rapid routine determination of amino acids in plasma by high-performance liquid chromatography with a 2-3 microns Spherisorb ODS II column. J Chromatogr 1993;620:143-8.

25. Wolfe RR, Chinkes DL. Isotope tracers in metabolic research. Wiley-Liss, New York. 2005.

26. Husek P. Amino acid derivatization and analysis in five minutes. FEBS Lett 1991;280:354-6.

27. Boirie Y, Gachon P, Corny S, Fauquant J, Maubois JL, Beaufrere B. Acute postprandial changes in leucine metabolism as assessed with an intrinsically labeled milk protein. Am J Physiol 1996;271:E1083-91.

28. Dangin M, Boirie Y, Garcia-Rodenas C, Gachon P, Fauquant J, Callier P, Ballevre O, Beaufrere B. The digestion rate of protein is an independent regulating factor of postprandial protein retention. Am $\mathrm{J}$ Physiol Endocrinol Metab 2001;280:E340-8.

29. Boirie Y, Gachon P, Beaufrere B. Splanchnic and whole-body leucine kinetics in young and elderly men. Am J Clin Nutr 1997;65:489-95.

30. Boirie $\mathrm{Y}$, Dangin M, Gachon P, Vasson MP, Maubois JL, Beaufrere B. Slow and fast dietary proteins differently modulate postprandial protein accretion. Proc Natl Acad Sci U S A 1997;94:14930-5.

31. Remond D, Machebeuf M, Yven C, Buffiere C, Mioche L, Mosoni L, Patureau Mirand P. Postprandial whole-body protein metabolism after a meat meal is influenced by chewing efficiency in elderly subjects. Am J Clin Nutr 2007;85:1286-92.

32. Atherton PJ, Etheridge T, Watt PW, Wilkinson D, Selby A, Rankin D, Smith K, Rennie MJ. Muscle full effect after oral protein: time-dependent concordance and discordance between human muscle protein synthesis and mTORC1 signaling. Am J Clin Nutr 2010;92:1080-8.

33. Buse MG, Reid SS. Leucine. A possible regulator of protein turnover in muscle. J Clin Invest 1975;56:1250-61.

34. Garlick PJ. The role of leucine in the regulation of protein metabolism. J Nutr 2005;135:1553S-6S.

35. Katsanos CS, Kobayashi H, Sheffield-Moore M, Aarsland A, Wolfe RR. A high proportion of leucine is required for optimal stimulation of the rate of muscle protein synthesis by essential amino acids in the elderly. Am J Physiol Endocrinol Metab 2006;291:E381-7. 

Chapter 7

General discussion 
ging is accompanied by a progressive decline in skeletal muscle mass,
termed sarcopenia. A possible key-factor in the etiology of sarcopenia is an
impaired muscle protein synthetic response to food intake with older age. In the present thesis, we describe a series of dietary interventions that were aimed to effectively increase the muscle protein synthetic response to dietary protein ingestion in older adults. In this final chapter, the implications of our findings will be discussed in a broader perspective and specific areas on which future research should focus will be identified.

\section{Anabolic resistance}

It has been well established that muscle protein synthesis and breakdown rates are highly responsive to food intake. Ingestion of protein and/or amino acids strongly stimulates muscle protein synthesis and inhibits protein breakdown rates, resulting in a positive net protein balance in both the young and the elderly (1). Interestingly, data from recent studies suggest that the muscle protein synthetic response to smaller, meal-like amounts of amino acids is attenuated in older subjects when compared with young controls $(2,3)$. This impaired muscle protein synthetic response to food intake has been proposed to represent one of the key-factors responsible in the development of sarcopenia. In Chapter 2, however, we did not observe an impaired muscle protein synthetic response to protein ingestion in the elderly when compared with the young. As such, our findings seem to be in contrast with the studies that did report 'anabolic resistance' to food intake in the elderly. Within these studies, postprandial muscle protein synthesis rates were assessed while plasma insulin levels were kept constant (using an insulin-clamp). In contrast, we assessed the muscle protein synthetic response under normal living conditions, i.e. following the ingestion of a single meal-like amount of protein. Ingestion of a single protein bolus results in a rapid increase in plasma amino acid availability that is accompanied by a rapid, but short-lived, postprandial peak in circulating insulin. The latter is relevant to facilitate postprandial nutritive blood flow which supports muscle protein synthesis by increasing amino acid delivery to the muscle (4). Therefore, our data suggest that there are no substantial differences in postprandial muscle protein synthesis rates between the young and the old under normal living conditions. However, it cannot be ignored that even minor changes $(<5 \%)$ in postprandial muscle protein synthesis rates with a more advanced age will become of great clinical relevance over the course of many years. In fact, such minor differences seem consistent with the natural progression of sarcopenia that develops over several decades (5). Presently, the detection of such small, but physiologically relevant, differences is limited due to the large inter-subject variance in muscle protein synthesis rates and the sensitivity of the measurement (6). Typically, a sample size of $8-12$ subjects per group is required to detect a $15-20 \%$ difference in muscle protein synthesis rates (Figure 1). 


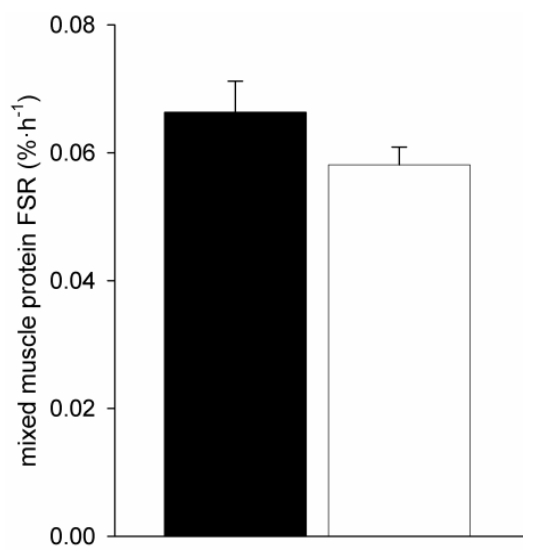

Figure 1. Mixed muscle protein fractional synthetic rates (FSR) in young (age, $22 \pm 1 \mathrm{yrs} ; \mathrm{n}=22$; black bar) and older (age, 70 \pm 1 yrs; $n=22$; white bar) men after ingesting 20-35 g of dairy protein $(7,8)$. Ingestion of intrinsically $\mathrm{L}-\left[1-{ }^{13} \mathrm{C}\right]$ phenylalanine-labeled protein using the plasma free pool to calculate FSR $(P=0.16)$.

Although we can only speculate on whether postprandial muscle protein synthesis is truly impaired with aging, it seems of more clinical relevance to determine whether we can augment the muscle protein synthetic response to food intake. To allow this we need to assess the impact of various key-factors that drive postprandial muscle protein synthesis, e.g. physical activity, protein digestion and absorption kinetics, the amino acid composition and the amount of the protein consumed.

\section{Physical activity}

Besides food intake, physical activity is considered the main anabolic stimulus for muscle mass preservation (9). A single bout of physical activity stimulates muscle protein synthesis as well as muscle protein breakdown rates, albeit the latter to a lesser extent $(10,11)$. These changes result in an improved net muscle protein balance (11). Although a single bout of physical activity stimulates muscle protein synthesis to a greater extent than protein breakdown, net muscle protein balance remains negative in the absence of food intake (11). Consequently, food intake following physical activity is required to obtain a net positive protein balance, allowing muscle hypertrophy to occur.

Because some level of physical activity generally precedes food intake in normal daily life, it seemed evident that the concept of anabolic resistance should be studied in a postprandial state both at rest and following physical activity. In Chapter 2, we show that more of the dietary protein-derived amino acids were used for de novo muscle protein synthesis when physical activity preceded protein ingestion. These findings indicate that exercised muscle becomes more sensitive to amino acid availability. This enhanced amino acid sensitivity of muscle protein 
synthesis has been reported to persist for up to $16 \mathrm{~h}$ in trained (12) and 24-48 $\mathrm{h}$ in untrained individuals (11-13) following a single bout of physical activity. For this reason, subjects are always asked to refrain from (exhaustive) physical activity in the $48 \mathrm{~h}$ prior to an experiment. This restriction, however, does not compensate for obvious differences in habitual physical activity levels between young and elderly subjects and their subsequent impact on muscle protein synthesis rates assessed in the laboratory. As such, it could be speculated that a more sedentary lifestyle is responsible for the proposed anabolic resistance to food intake in the elderly. In agreement, it has been shown that muscle disuse also results in a reduced sensitivity of skeletal muscle tissue to anabolic stimuli such as food intake (14) and physical activity (15). With older people experiencing more frequent periods of bed rest due to illness or hospitalization it is clear that muscle disuse also contributes to the loss of muscle mass and strength at a more advanced age (16).

In conclusion, habitual physical activity is an important factor modulating the muscle protein synthetic response to food intake. Increasing the duration and intensity of habitual physical activity, therefore, may represent an effective strategy to preserve muscle mass.

\section{Protein digestion and absorption kinetics}

Following protein ingestion, the kinetics of protein digestion and absorption determine at which rate the dietary protein-derived amino acids become available in the circulation (17). This rate has been proposed to represent a key-factor regulating postprandial muscle protein synthesis (18). However, protein digestion and amino acid absorption kinetics seem to affect postprandial muscle protein retention differently at a more advanced age (19). Whereas young adults show a more positive whole-body protein balance following ingestion of a slow digestible protein, older adults show a more positive whole-body protein balance following a faster digestible protein (20). In Chapter 3, we extended on these findings by showing that the ingestion of faster digestible protein sources results in greater muscle protein synthesis rates when compared with the ingestion of more slowly digestible protein.

Recent work suggests that peak muscle protein synthesis rates are reached within 45 - 90 min following protein ingestion after which they return to baseline values. The latter would occur even under conditions where increased plasma amino acid availability is maintained (21). Consequently, many other studies have used 2-3 $\mathrm{h}$ timeframes to assess (peak) postprandial muscle protein synthesis rates in young and older subjects. In contrast to examining such 'peak' postprandial muscle protein synthesis rates, we were more interested in an aggregated response to assess how much of the dietary protein was used for de novo muscle protein synthesis. In our experiments we observed that amino acids derived from slowly digestible protein were still being released from the gut $6 \mathrm{~h}$ after protein ingestion (Chapter 
3). Therefore, when comparing the impact of slow versus more rapidly digestible proteins, it may be of more relevance to assess the aggregated muscle protein synthetic response over an extended postprandial period. Whether assessing an aggregated response is more (or less) relevant than assessing 'peak' values of muscle protein synthesis following protein ingestion remains to be established. Interestingly, however, is the observation that the peak muscle protein synthetic response to food intake may be delayed in the elderly compared with the young (22).

In a habitual diet, we hardly ever consume only 'fast' or 'slow' protein sources. In fact, most meals consist of different protein sources and combine protein with other macronutrients (23). Therefore, meal composition might be an important factor that affects digestion and absorption kinetics of dietary protein and its subsequent effect on muscle protein synthesis. For example, co-ingestion of other macronutrients has been reported to affect gastric emptying (24) and modulate splanchnic extraction of dietary protein (25). Besides the composition of a meal, the matrix of the food and its mastication are likely important factors that drive protein digestion and absorption kinetics. Normally, chewing is the first transformation process of consumed food on its way to the gut. Aging has been associated with decreased chewing efficiency, leading to a lower disruption of swallowed food (26). Chewing efficiency is even more compromised in subjects with impaired mastication such as those wearing dentures (27). So far, most studies have used (milk) protein drinks to study postprandial muscle protein synthesis. As such, the impact of food matrix and proper mastication has not received much attention. To provide more insight in the effect of chewing and texture on postprandial protein metabolism, we used intrinsically labeled meat that was produced by infusing a cow with large quantities of labeled phenylalanine (Chapter 5). In Chapter 6, we show that minced beef is more rapidly digested and absorbed when compared with beef steak and increases subsequent postprandial protein retention more effectively in the elderly. Whether differences in heat treatment during the preparation of meat (i.e. cooking) have a similar effect on protein digestion and absorption kinetics remains to be established. Interestingly, however, are results from previous work with labeled egg protein showing that the digestibility of cooked egg protein was far greater than of raw egg protein (28). Taken together, the aforementioned examples show that a more holistic view is required to increase our understanding of the relevance of food composition, matrix, mastication, and processing on protein digestion and absorption kinetics and subsequent postprandial muscle protein synthesis.

\section{Amino acid composition}

An increase in essential amino acid (EAA) availability represents the main anabolic signal responsible for stimulating postprandial muscle protein synthesis rates (29). 
Therefore, besides digestion and absorption kinetics, also the amino acid composition of a dietary protein source determines its anabolic properties. In Chapter 3, we compared postprandial protein synthesis rates following ingestion of whey, casein and casein hydrolysate in older men. In these experiments, a significant positive correlation was observed between the delta peak increase in EAA concentrations and the overall postprandial muscle protein synthetic response. Interestingly, the strongest correlation was observed for leucine. The latter likely explains, at least partly, the greater muscle protein synthetic response observed following ingestion of whey versus casein or casein hydrolysate. These findings seem to be in line with earlier work reporting that increasing the leucine content of a meal could compensate for the level of anabolic resistance by increasing the postprandial muscle protein synthetic response to food intake in the elderly $(30,31)$. However, more recent long-term intervention trials were unable to confirm that leucine coingestion with each main meal increases net muscle mass gain in an elderly population $(32,33)$. These trials suggest that effective dietary interventions to combat sarcopenia will take more than just increasing the leucine content of a meal. In accordance, in Chapter 3, we also report significant positive correlations between the overall postprandial muscle protein synthetic response and the delta peak increase in concentration of 5 other EAAs. As such, more research is warranted to underpin the specific interactions between leucine and other (essential) amino acids that may drive the anabolic response to food intake.

\section{The amount of protein}

The muscle protein synthetic response to food intake is dependent on both the quality as well as the quantity of dietary protein ingested $(34,35)$. In Chapter 4 , we show that the postprandial muscle protein synthetic response to whey protein ingestion is dose-dependent in elderly men. However, it should be noted that this dose-dependency is likely specific for fast digestible protein sources. Comparing work from our lab on dietary protein digestion and absorption kinetics following ingestion of intact casein by older adults, we observed that the ingestion of $35 \mathrm{~g}$ (36) versus $20 \mathrm{~g} \mathrm{(37)} \mathrm{intact} \mathrm{casein} \mathrm{did} \mathrm{not} \mathrm{result} \mathrm{in} \mathrm{higher} \mathrm{peak} \mathrm{values} \mathrm{of} \mathrm{dietary}$ protein-derived phenylalanine absorption from the gut. In contrast, when similar amounts of fast digestible casein hydrolysate were consumed, large differences in peak values were observed between $35 \mathrm{~g}$ and $20 \mathrm{~g}$ protein (Figure 2).

In our experiments, we observed that approximately $50-60 \%$ of the dietary proteinderived phenylalanine became available in the circulation during the $6 \mathrm{~h}$ postprandial assessment period. Consequently, a large amount of dietary amino acids did not appear in the circulation following food intake. The metabolic fate of these amino acids remains to be elucidated. Apart from some non-absorption and oxidation, it is likely that most of these amino acids are retained in the gut and are used 
for de novo protein synthesis in the splanchnic tissues (e.g. liver, gut, intestine) (38, 39).

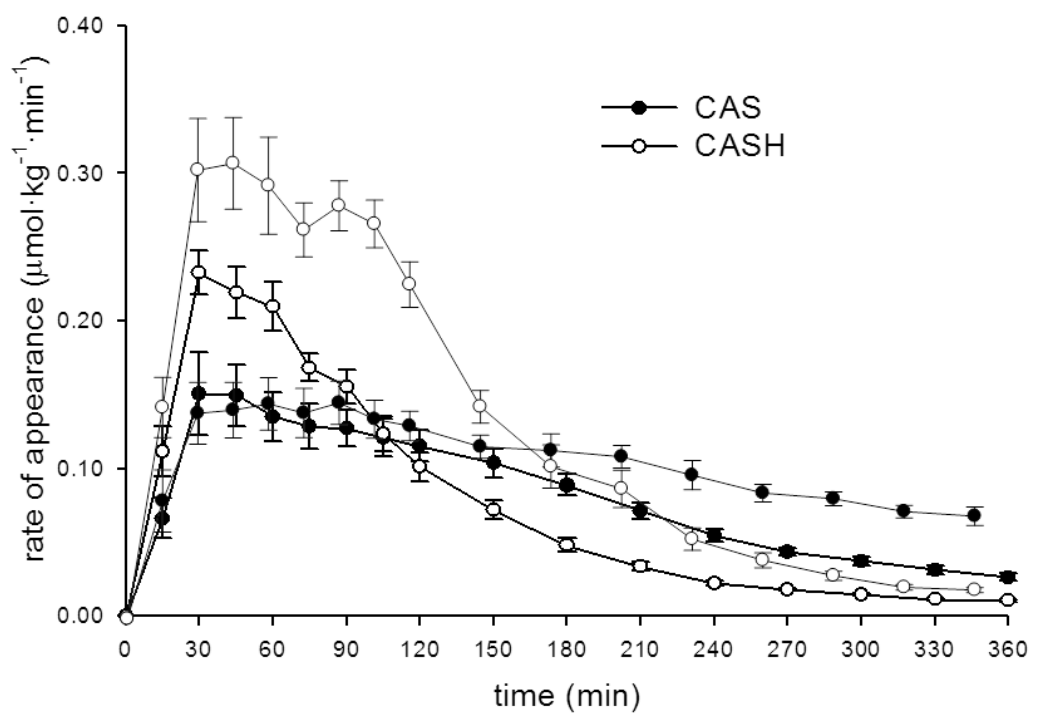

Figure 2. Rate of appearance of dietary protein-derived phenylalanine from the gut into the circulation following ingestion of $20 \mathrm{~g}$ and $35 \mathrm{~g}$ intact casein (CAS) and hydrolyzed casein (CASH) by elderly men. Combined results of Koopman et al. (36) and Pennings et al. (37).

Previous work in humans (40) and pigs (41) has shown that the splanchnic area extracts $\sim 50 \%$ of the ingested amino acids to sustain its functional mass. This magnitude of splanchnic extraction is not surprising considering the mass and high protein turnover rates of the various organs (1). In addition, extracted amino acids will also be used for de novo synthesis of plasma proteins $(38,42)$. Following meal consumption, plasma albumin synthesis was shown to be a significant contributor to whole-body protein synthesis $(43,44)$. Interestingly, it was suggested that the stimulation of albumin synthesis observed during feeding prevents irreversible oxidative losses of a significant fraction of ingested EAAs and may serve as a vehicle to capture excess dietary amino acids and transport them to peripheral tissues to sustain local protein synthesis (43). Whether the latter also represents a significant contributor to muscle protein synthesis following meal consumption remains to be determined. Therefore, further evaluation of the metabolic fate of dietary amino acids extracted by the splanchnic tissues will be instrumental to provide greater insight in postprandial protein metabolism.

\section{General conclusions and future research}

In the present thesis, a series of dietary interventions were tested to effectively increase the muscle protein synthetic response to food intake in older adults. The 
uniqueness of the experiments that were performed is the use of intrinsically labeled dietary protein of which the production was described in Chapter 5. Intrinsically labeled milk and meat protein were used to assess in vivo protein digestion and absorption kinetics and subsequent (muscle) protein synthesis rates following consumption of a single bolus of dietary protein.

The first experiments indicated that exercised muscle is more sensitive to the availability of amino acids and that this responsiveness to physical activity is preserved at an advanced age. This makes physical activity and/or exercise an important factor in muscle mass preservation. The following series of experiments focused on quality and quantity of dietary protein and showed that the ingestion of faster digestible protein sources augments postprandial muscle protein synthesis rates more effectively than slower digestible protein sources in older adults. In addition, it was also shown that the amino acid composition of dietary protein (e.g. high in leucine) is an important factor that drives the muscle protein synthetic response to food intake. Whey protein seems to represent a more effective dietary component in the diet of older adults. However, the amount of whey protein that should be ingested in a single meal to maximize postprandial muscle protein synthesis was observed to be at least $35 \mathrm{~g}$.

The performed experiments have increased our knowledge on postprandial protein metabolism. Nonetheless, there are many questions that remain because a normal, healthy diet generally provides many different protein sources in combination with other food components. Therefore, future research is required to combine all data and define more practical dietary recommendations to stimulate muscle mass preservation during aging. Questions that should be addressed in such future research include:

- How will the intensity of physical activity affect protein digestion and absorption kinetics? Will this be different between young and older individuals?

- Are potential differences in postprandial (peak) muscle protein synthesis rates between young and older subjects detected at 1-2 $\mathrm{h}$ after food ingestion more (or less) relevant than responses determined over an aggregated time interval (e.g. 0-6 h)?

- Does co-ingestion of dietary carbohydrate and/or fat affect protein digestion and absorption kinetics and subsequent muscle protein synthesis rates? Is such an effect also age-dependent?

- Does heat treatment of dietary protein affect protein digestion and absorption kinetics and subsequent muscle protein synthesis rates in older 
adults? How does food processing and/or preparation modulate the postprandial muscle protein synthetic response?

- Should the plasma concentrations of other (essential) amino acids be increased (or decreased) together with leucine to allow for a greater muscle protein synthetic response to food intake?

- What is the metabolic fate of dietary amino acids extracted by the splanchnic tissues following ingestion of a single meal?

- How relevant is the postprandial inhibition of muscle protein breakdown for muscle mass preservation? Are there age-related differences in the postprandial muscle protein breakdown response to food intake? 


\section{References}

1. Waterlow JC. Protein turnover. CABI, Oxfordshire 2006.

2. Cuthbertson $D$, Smith $K$, Babraj J, et al. Anabolic signaling deficits underlie amino acid resistance of wasting, aging muscle. FASEB J 2005;19:422-4.

3. Guillet $\mathrm{C}$, Prod'homme M, Balage $\mathrm{M}$, et al. Impaired anabolic response of muscle protein synthesis is associated with S6K1 dysregulation in elderly humans. FASEB J 2004;18:1586-7.

4. Clark MG, Rattigan S, Barrett EJ. Nutritive blood flow as an essential element supporting muscle anabolism. Curr Opin Clin Nutr Metab Care 2006;9:185-9.

5. Short KR, Vittone JL, Bigelow ML, Proctor DN, Nair KS. Age and aerobic exercise training effects on whole body and muscle protein metabolism. Am J Physiol Endocrinol Metab 2004;286:E92-101.

6. Smith GI, Patterson BW, Mittendorfer B. Human muscle protein turnover--why is it so variable? J Appl Physiol 2011;110:480-91.

7. Pennings $B$, Koopman R, Beelen $M$, Senden JM, Saris $W H$, van Loon $L$. Exercising before protein intake allows for greater use of dietary protein-derived amino acids for de novo muscle protein synthesis in both young and elderly men. Am J Clin Nutr 2011;93:322-31.

8. Koopman $\mathrm{R}$, Walrand $\mathrm{S}$, Beelen $\mathrm{M}$, et al. Dietary protein digestion and absorption rates and the subsequent postprandial muscle protein synthetic response do not differ between young and elderly men. J Nutr 2009;139:1707-13.

9. Koopman R, van Loon UC. Aging, exercise and muscle protein metabolism. J Appl Physiol 2009;106:2040-8.

10. Biolo G, Maggi SP, Williams BD, Tipton KD, Wolfe RR. Increased rates of muscle protein turnover and amino acid transport after resistance exercise in humans. Am J Physiol 1995;268:E514-20.

11. Phillips SM, Tipton KD, Aarsland A, Wolf SE, Wolfe RR. Mixed muscle protein synthesis and breakdown after resistance exercise in humans. Am J Physiol 1997;273:E99-107.

12. Tang JE, Perco JG, Moore DR, Wilkinson SB, Phillips SM. Resistance training alters the response of fed state mixed muscle protein synthesis in young men. Am J Physiol Regul Integr Comp Physiol 2008;294:R172-8.

13. Chesley A, MacDougall JD, Tarnopolsky MA, Atkinson SA, Smith K. Changes in human muscle protein synthesis after resistance exercise. J Appl Physiol 1992;73:1383-8.

14. Drummond MJ, Dickinson JM, Fry CS, et al. Bed rest impairs skeletal muscle amino acid transporter expression, mTORC1 signaling, and protein synthesis in response to essential amino acids in older adults. Am J Physiol Endocrinol Metab 2012;302:E1113-22.

15. Suetta $C$, Hvid $L G$, Justesen $L$, et al. Effects of aging on human skeletal muscle after immobilization and retraining. J Appl Physiol 2009;107:1172-80.

16. Kortebein $P$, Symons TB, Ferrando A, et al. Functional impact of 10 days of bed rest in healthy older adults. J Gerontol A Biol Sci Med Sci 2008;63:1076-81.

17. Boirie $Y$, Dangin M, Gachon $P$, Vasson MP, Maubois JL, Beaufrere B. Slow and fast dietary proteins differently modulate postprandial protein accretion. Proc Natl Acad Sci U S A 1997;94:14930-5.

18. Dangin $M$, Boirie $Y$, Garcia-Rodenas $C$, et al. The digestion rate of protein is an independent regulating factor of postprandial protein retention. Am J Physiol Endocrinol Metab 2001;280:E340-8.

19. Dangin M, Guillet C, Garcia-Rodenas C, et al. The rate of protein digestion affects protein gain differently during aging in humans. J Physiol 2003;549:635-44.

20. Dangin $M$, Boirie $Y$, Guillet $C$, Beaufrere $B$. Influence of the protein digestion rate on protein turnover in young and elderly subjects. J Nutr 2002;132:3228S-33S.

21. Atherton PJ, Etheridge T, Watt PW, et al. Muscle full effect after oral protein: time-dependent concordance and discordance between human muscle protein synthesis and mTORC1 signaling. Am J Clin Nutr 2010;92:1080-8.

22. Drummond MJ, Dreyer HC, Pennings B, et al. Skeletal muscle protein anabolic response to resistance exercise and essential amino acids is delayed with aging. J Appl Physiol 2008;104:1452-61. 
23. Tieland $\mathrm{M}$, Borgonjen-Van den Berg KJ, van Loon $\mathrm{LJ}$, de Groot LC. Dietary protein intake in community-dwelling, frail, and institutionalized elderly people: scope for improvement. Eur J Nutr 2012;51:173-9.

24. Low AG. Nutritional regulation of gastric secretion, digestion and emptying. Nutr Res Rev 1990;3:229-52.

25. Fouillet H, Gaudichon C, Mariotti F, Bos C, Huneau JF, Tome D. Energy nutrients modulate the splanchnic sequestration of dietary nitrogen in humans: a compartmental analysis. Am J Physiol Endocrinol Metab 2001;281:E248-60.

26. Mioche L, Bourdiol P, Peyron MA. Influence of age on mastication: effects on eating behaviour. Nutr Res Rev 2004;17:43-54.

27. Remond D, Machebeuf M, Yven C, et al. Postprandial whole-body protein metabolism after a meat meal is influenced by chewing efficiency in elderly subjects. Am J Clin Nutr 2007;85:1286-92.

28. Evenepoel P, Geypens B, Luypaerts A, Hiele M, Ghoos Y, Rutgeerts P. Digestibility of cooked and raw egg protein in humans as assessed by stable isotope techniques. J Nutr 1998;128:1716-22.

29. Volpi E, Kobayashi H, Sheffield-Moore M, Mittendorfer B, Wolfe RR. Essential amino acids are primarily responsible for the amino acid stimulation of muscle protein anabolism in healthy elderly adults. Am J Clin Nutr 2003;78:250-8.

30. Katsanos CS, Kobayashi H, Sheffield-Moore M, Aarsland A, Wolfe RR. A high proportion of leucine is required for optimal stimulation of the rate of muscle protein synthesis by essential amino acids in the elderly. Am J Physiol Endocrinol Metab 2006;291:E381-7.

31. Rieu I, Balage $M$, Sornet $C$, et al. Leucine supplementation improves muscle protein synthesis in elderly men independently of hyperaminoacidaemia. J Physiol 2006;575:305-15.

32. Verhoeven S, Vanschoonbeek K, Verdijk LB, et al. Long-term leucine supplementation does not increase muscle mass or strength in healthy elderly men. Am J Clin Nutr 2009;89:1468-75.

33. Leenders M, Verdijk LB, van der Hoeven L, et al. Prolonged leucine supplementation does not augment muscle mass or affect glycemic control in elderly type 2 diabetic men. J Nutr 2011;141:1070-6.

34. Walrand S, Boirie Y. Optimizing protein intake in aging. Curr Opin Clin Nutr Metab Care 2005;8:8994.

35. Paddon-Jones D, Rasmussen BB. Dietary protein recommendations and the prevention of sarcopenia. Curr Opin Clin Nutr Metab Care 2009;12:86-90.

36. Koopman R, Crombach N, Gijsen AP, et al. Ingestion of a protein hydrolysate is accompanied by an accelerated in vivo digestion and absorption rate when compared with its intact protein. Am J Clin Nutr 2009;90:106-15.

37. Pennings B, Boirie $Y$, Senden JM, Gijsen AP, Kuipers $H$, van Loon $L$. Whey protein stimulates postprandial muscle protein accretion more effectively than do casein and casein hydrolysate in older men. Am J Clin Nutr 2011;93:997-1005.

38. Fouillet H, Gaudichon C, Bos C, Mariotti F, Tome D. Contribution of plasma proteins to splanchnic and total anabolic utilization of dietary nitrogen in humans. Am J Physiol Endocrinol Metab 2003;285:E88-97.

39. Stoll B, Burrin DG. Measuring splanchnic amino acid metabolism in vivo using stable isotopic tracers. J Anim Sci 2006;84 Suppl:E60-72.

40. Biolo $G$, Tessari $P$, Inchiostro $S$, et al. Leucine and phenylalanine kinetics during mixed meal ingestion: a multiple tracer approach. Am J Physiol 1992;262:E455-63.

41. Deutz NE, Bruins MJ, Soeters PB. Infusion of soy and casein protein meals affects interorgan amino acid metabolism and urea kinetics differently in pigs. J Nutr 1998;128:2435-45.

42. Jaleel A, Nehra V, Persson XM, Boirie Y, Bigelow M, Nair KS. In vivo measurement of synthesis rate of multiple plasma proteins in humans. Am J Physiol Endocrinol Metab 2006;291:E190-7.

43. De Feo P, Horber FF, Haymond MW. Meal stimulation of albumin synthesis: a significant contributor to whole body protein synthesis in humans. Am J Physiol 1992;263:E794-9. 


\section{CHAPTER 7}

44. Cayol M, Boirie Y, Rambourdin F, et al. Influence of protein intake on whole body and splanchnic leucine kinetics in humans. Am J Physiol 1997;272:E584-91. 

Summary 
A ging is accompanied by a progressive decline in skeletal muscle mass, termed sarcopenia, which is associated with functional impairments in daily living activities, the loss of independence, and an increased risk of developing chronic metabolic disease. A possible key-factor in the etiology of sarcopenia is an impaired muscle protein synthetic response to food intake at a more advanced age. In the present thesis, a series of dietary interventions were tested to effectively increase the muscle protein synthetic response to food intake in older adults. The uniqueness of the experiments that were performed is the use of intrinsically labeled milk and meat protein which allows the in vivo assessment of dietary protein digestion and absorption kinetics as well as subsequent (muscle) protein synthesis rates following consumption of a single bolus of protein.

In Chapter 2, we first compared dietary protein digestion and absorption kinetics and subsequent postprandial muscle protein synthesis rates following ingestion of a meal-like amount of protein between young and older adults. Because some level of physical activity generally precedes food intake in normal daily life, we assessed the postprandial muscle protein synthetic response both at rest and following physical activity. These experiments indicated that exercised muscle is more sensitive to the availability of amino acids and that this responsiveness to physical activity is preserved at an advanced age. This makes physical activity or exercise an important factor in muscle mass preservation.

The following series of experiments focused on quality (Chapter 3) and quantity (Chapter 4 ) of dietary protein and show that ingestion of more rapidly digestible protein sources increases postprandial muscle protein synthesis rates more effectively than slower digestible protein sources in older adults. In addition, it is also shown that the amino acid composition of dietary protein (e.g. high in leucine) represents an important factor driving the postprandial muscle protein synthetic response. Whey protein seems to represent a dietary protein source with the greater muscle protein synthetic response when ingested by older adults. The amount of whey protein that should be ingested in a single meal to maximize the muscle protein synthetic response was observed to be at least $35 \mathrm{~g}$.

In Chapter 5, we describe the production of intrinsically labeled milk protein with an enrichment level that allows us to assess dietary protein digestion and absorption kinetics as well as subsequent de novo muscle protein accretion. Furthermore, we show the feasibility of producing intrinsically labeled meat protein that allows the in vivo assessment of protein digestion and absorption kinetics following beef consumption in humans. We extended on the latter in Chapter 6 by determining the effect of meat texture on digestion and absorption kinetics and subsequent postprandial protein retention in older adults. Therefore, older men were randomly assigned to a cross-over experiment in which they consumed intrinsically L-[1${ }^{13} \mathrm{C}$ ]phenylalanine-labeled beef, provided as a steak or as minced beef. As a result, 
we report that minced beef is more rapidly digested and absorbed when compared with beef steak, resulting in greater postprandial protein retention in older men.

In, Chapter $\mathbf{7}$ the implications of our findings are discussed in a broader perspective and specific areas on which future research should focus are identified. There are many questions that remain to be addressed because a normal, healthy diet generally provides many different protein sources in combination with other food components. Future research is required to combine all data and define more practical dietary recommendations to support muscle mass preservation during aging. 



\section{Samenvatting}


uderdom gaat gepaard met een progressieve afname van de hoeveelheid skeletspiermassa. Dit proces wordt ook wel sarcopenie genoemd en gaat veelal gepaard met fysieke beperkingen bij het uitvoeren van de dagelijkse activiteiten, het verlies van de eigen onafhankelijkheid, en een verhoogd risico op het ontwikkelen van chronisch metabole ziekten. Een mogelijk belangrijke factor in het ontstaan van sarcopenie is een verminderde opbouw van spiereiwit in oudere personen na de maaltijd. In dit proefschrift zijn een serie voedingsinterventies getest om de opbouw van spiereiwit in oudere personen effectief te verhogen. Het bijzondere aan deze testen is het gebruik van intrinsiek gelabelde eiwitten uit melk en vlees, waarvan de productie staat beschreven in hoofdstuk 5. Met behulp van deze eiwitten kan zowel de snelheid van eiwitvertering en -opname als ook de opbouw van skeletspiereiwit worden bepaald na een maaltijd.

In hoofdstuk 2 testten we eerst de snelheid van eiwitvertering en -opname als ook de opbouw van skeletspiereiwit in jonge en oudere volwassenen na de inname van een melkeiwitdrankje We hebben dit zowel in rust als ook na fysieke inspanning getest aangezien, in het dagelijks leven, een bepaalde mate van fysieke inspanning vaak vooraf gaat aan de maaltijd Deze experimenten hebben aangetoond dat de skeletspieren na fysieke inspanning gevoeliger zijn voor de beschikbaarheid van eiwitten uit de voeding en dat deze gevoeligheid behouden blijft op hogere leeftijd. Dit maakt fysieke inspanning of sporten tot een belangrijke factor bij het behoud van de skeletspiermassa.

De volgende serie experimenten waren gericht op de kwaliteit (hoofdstuk 3) en kwantiteit (hoofdstuk 4) van eiwitten in de maaltijd. Deze experimenten toonden aan dat snel verteerbare eiwitten effectiever zijn in het verhogen van de opbouw van skeletspiereiwit dan langzaam verteerbare eiwitten in oudere personen. Verder toonden deze experimenten aan dat ook de aminozuursamenstelling van eiwitten in de maaltijd (o.a. veel leucine) een belangrijke factor is in het verhogen van de opbouw van skeletspiereiwit na de maaltijd. De consumptie van wei-eiwit, dat snel verteerbaar is en veel leucine bevat, bleek bijzonder effectief te zijn in het verhogen van de opbouw van skeletspiereiwit in oudere personen. De hoeveelheid wei-eiwit die in een enkele maaltijd moet worden geconsumeerd om de opbouw van skeletspiereiwit maximaal te verhogen bedraagt tenminste $35 \mathrm{~g}$.

In hoofdstuk $\mathbf{5}$ beschrijven we de productie van intrinsiek gelabeld melkeiwit met een dermate hoge labeling waarmee zowel de snelheid van eiwitvertering en opname als ook de opbouw van skeletspiereiwit kan worden bepaald na een maaltijd. Daarnaast tonen we aan dat het ook mogelijk is om intrinsiek gelabeld vlees te maken waarmee de snelheid van eiwitvertering en -opname in mensen kan worden bepaald na vleesconsumptie.

In hoofdstuk 6 testten we het effect van vleesstructuur, intact (biefstuk) of gemalen (tartaar) rundvlees, op zowel de snelheid van eiwitvertering en -opname als ook de opbouw van lichaamseiwit in oudere personen na de maaltijd. Deze expe- 
rimenten toonden aan dat de eiwitten uit tartaar sneller worden verteerd en opgenomen dan de eiwitten uit biefstuk, wat vervolgens resulteerde in een hogere eiwitretentie.

In hoofdstuk 7 worden de resultaten van onze experimenten in een bredere context geplaatst en worden specieke richtingen voor toekomstig onderzoek geïdentificeerd. Er blijven nog vele vragen onbeantwoord aangezien een normaal, gezond dieet vele verschillende eiwitbronnen bevat in combinatie met andere voedingscomponenten. Daarom is vervolgonderzoek, op basis van de in dit proefschrift beschreven resultaten, noodzakelijk om meer praktisch voedingsadvies te kunnen geven voor het beter behouden van de skeletspiermassa gedurende het ouder worden. 



\section{Acknowledgements}


have considered the opportunity to work towards a PhD-degree as a privilege and I have enjoyed my time as a PhD-candidate very much. Therefore, I want to acknowledge everyone who has made a contribution, either big or small, to the work presented in this thesis, and as such, supported me to obtain the PhD-degree. In particular, I would like to thank the enthusiastic support of the volunteers who participated in the experiments. I have greatly appreciated the fantastic collegiality and comradery of the Maastricht Muscle Metabolism (M3) research group and the hard work and dedication of my PhD-supervisor, Prof. Luc van Loon.

During my time as a PhD-candidate, I have experienced some wonderful highlights in my personal life: getting married, becoming a father, buying and rebuilding a house. I'm very grateful for the love and support of my wife, family and friends during these very nice, but also very busy, times. I love you.

Thank you, thank you very much! 



\section{Curriculum Vitae}


B art Pennings was born on September $2^{\text {nd }} 1981$ in Eindhoven, the Netherlands. He completed secondary school at the Bisschop Bekkers College in Eindhoven in 1999. In the same year, he started his academic education at the Technical University of Eindhoven where he studied Chemical Engineering. Driven by a personal interest in biochemistry within the human body following nutrition and exercise, he switched to the Wageningen University in 2003 where he studied nutritional physiology. He obtained a Master of Science degree in Human Nutrition and Health in 2006, after a full year research-internship with Prof. Luc van Loon at Maastricht University. During this internship, he collaborated on human intervention studies to assess the impact of sports nutrition on post-exercise muscle protein balance.

Directly after receiving his Masters degree, Bart started working at the University of Texas Medical Branch (USA) with Profs. Blake Rasmussen and Elena Volpi for 6 months to investigate the impact of aging on the muscle protein synthetic response to nutrition and exercise. Upon his return to the Netherlands in 2007, he joined the research group of Prof. Van Loon again to work towards a PhD-degree, which resulted in this thesis. In 2010, he received a Young Investigator Award from the European College of Sport Science for his presentation on the work described in chapter 2. Since 2011, Bart has been working as a scientist at Danone Research where he continues his work on protein metabolism in infant and medical nutrition.

Bart Pennings is married with Maloe Olfers and father of a son (Beau). 



\section{List of publications}


Minced beef is more rapidly digested and absorbed when compared with beef steak, resulting in a more positive protein balance in older men

Pennings B, Groen BBL, van Dijk JW, de Lange A, Kiskini A, Kuklinski M, Senden JMG, van Loon LJC.

Under review

Dietary protein digestion and absorption are impaired during acute post-exercise recovery in young men

Van Wijck K, Pennings B, van Bijnen AA, Senden JM, Dejong CHC, Buurman WA, van Loon LJ, Lenaerts $\mathrm{K}$.

Am J Physiol Regul Integr Comp Physiol. 2013 Jan 2. [Epub ahead of print]

The single biopsy approach is reliable for the measurement of muscle protein synthesis rates in vivo in older men

Burd NA, Pennings B, Groen BBL, Gijsen AP, Senden JMG, van Loon LJC.

J Appl Physiol. 2012 Sep;113(6):896-902

Amino acid absorption and subsequent muscle protein accretion following graded intakes of whey protein in elderly men

Pennings B, Groen BBL, de Lange A, Gijsen AP, Zorenc AH, Senden JMG, and van Loon LJC.

Am J Physiol Endocrinol Metab. 2012 Apr;302(8):E992-9

Protein ingestion prior to sleep improves post-exercise overnight recovery

Res PT, Groen BBL, Pennings B, Beelen M, Wallis GA, Gijsen AP, Senden JMG, van Loon LJC

Med Sci Sports Exerc. 2012 Aug;44(8):1560-9

Intra-gastric protein administration stimulates overnight muscle protein synthesis in elderly men

Groen BBL, Res PT, Pennings B, Hertle E, Senden JMG, Saris WH, van Loon LJC.

Am J Physiol Endocrinol Metab. 2012 Jan;302(1):E52-60

The production of intrinsically labeled milk and meat protein is feasible and provides functional tools for human nutrition research

Pennings B, Pellikaan WF, Senden JMG, van Vuuren AM, Sikkema J, van Loon LJC.

J Dairy Sci. 2011 Sep;94(9):4366-73

The impact of protein co-ingestion on muscle protein synthesis during continuous endurance-type exercise

Beelen M, Zorenc AH, Pennings B , Senden JMG, Kuipers H, van Loon LJC. 
Whey protein stimulates postprandial muscle protein accretion more effectively than do casein and casein hydrolysate in older men

Pennings B, Boirie Y, Senden JMG, Gijsen AP, Kuipers H, van Loon LJC.

Am J Clin Nutr. 2011 May;93(5):997-1005

Exercising before protein intake allows for greater use of dietary protein-derived amino acids for de novo muscle protein synthesis in both young and elderly men Pennings B, Koopman R, Beelen M, Senden JMG, Saris WH, van Loon LJC.

Am J Clin Nutr. 2011 Feb:93(2):322-331

Prevalence of daily hyperglycemia in obese type $\mathbf{2}$ diabetic men compared with that in lean and obese normo-glycemic men: effect of consumption of a sucrosecontaining beverage

Manders RJ, Pennings B, Beckers CP, Aipassa TI, van Loon LJC.

Am J Clin Nutr. 2009 Sep;90(3):511-8

Expression of growth-related genes in young and older human skeletal muscle following an acute stimulation of protein synthesis

Drummond MJ, Miyazaki M, Dreyer HC, Pennings B, Dhanani S, Volpi E, Esser KA, Rasmussen BB.

J Appl Physiol. 2009 Apr;106(4):1403-11

Skeletal muscle protein anabolic response to resistance exercise and essential amino acids is delayed with aging

Drummond MJ, Dreyer HC, Pennings B, Fry CS, Dhanani S, Dillon EL, SheffieldMoore M, Volpi E, Rasmussen BB.

J Appl Physiol. 2008 May;104(5):1452-61

Leucine-enriched essential amino acid and carbohydrate ingestion following resistance exercise enhances mTOR signaling and protein synthesis in human muscle

Dreyer HC, Drummond MJ, Pennings B , Fujita S, Glynn EL, Chinkes DL, Dhanani S, Volpi E, Rasmussen BB.

Am J Physiol Endocrinol Metab. 2008 Feb;294(2):E392-400

Co-ingestion of carbohydrate with protein does not further augment postexercise muscle protein synthesis

Koopman R, Beelen M, Stellingwerff T, Pennings B , Saris WH, Kies AK, Kuipers $H$ van Loon LJC. 
Am J Physiol Endocrinol Metab. 2007 Sep;293(3)

Protein ingestion further augments S6K1 phosphorylation in skeletal muscle following resistance-type exercise in males

Koopman R, Pennings B, Zorenc AH, van Loon LJC.

J Nutr. 2007 Aug;137(8):1880-6 

Financial support 
Financial support by the following companies for the publication of this thesis is gratefully acknowledged:

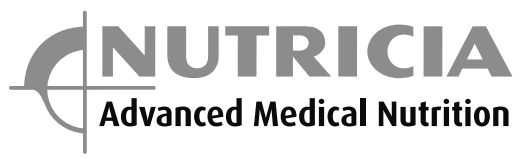

\section{*) \\ DANONE RESEARCH}
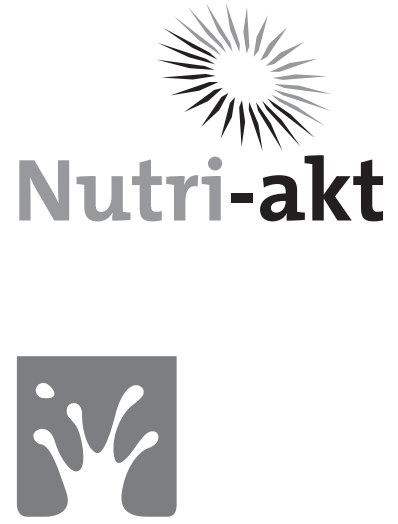

\section{nzo}

nederlandse zuivel organisatie
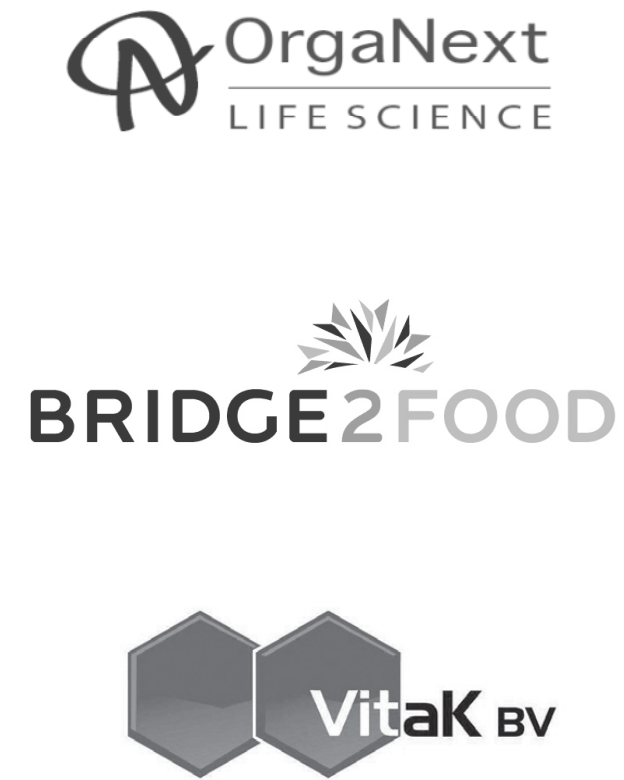
